Jane de Souza Silva

\title{
Urbanização de favela em área de proteção de mananciais: O Caso da Comunidade Sete de Setembro
}

Dissertação apresentada à Escola Politécnica da Universidade de São Paulo para obtenção do título de Mestre em Engenharia 
ESCOLA POLITÉCNICA DA UNIVERSIDADE DE SÃO PAULO

DEPARTAMENTO DE ENGENHARIA DE CONSTRUÇÃO CIVIL

Jane de Souza Silva

\section{Urbanização de favela em áreas de proteção de mananciais: O Caso da Comunidade Sete de Setembro}

Dissertação apresentada à Escola Politécnica da Universidade de São Paulo para obtenção do título de Mestre em Engenharia

Área de concentração: Engenharia de Construção Civil e Urbana

Orientador:

Prof. Dr. Alex Kenya Abiko 
Este exemplar foi revisado e alterado em relação à versão original, sob responsabilidade única do autor e com anuência de seu orientador.

São Paulo, 28 de Março de 2003.

Assinatura do autor

Assinatura do orientador

FICHA CATALOGRÁFICA

Silva, Jane de Souza

Urbanização de favela em área de proteção de mananciais:

O Caso da Comunidade Sete de Setembro / Jane de Souza Silva.

- ed. rev. - São Paulo, 2003

118p.

Dissertação (Mestrado) - Escola Politécnica da Universidade de

São Paulo. Departamento de Engenharia de Construção Civil.

1. Urbanização 2. Favelas 3. Avaliação pós-ocupação 4. Planejamento territorial urbano I. Universidade de São Paulo. Escola Politécnica. Departamento de Construção Civil II. t. 


\section{Dedico ...}

Ao meu pai - Leonardo José da Silva - que sempre sonhou e lutou para ter seus filhos formados.

À minha mãe - Joana de Souza - guerreira incansável, cuja força me inspira a cada dia.

E à minha amada filha Letícia por me fazer brotar o amor mais puro e incondicional ... 


\section{Agradeço ...}

Ao professor Alex Kenya Abiko pela orientação deste trabalho e também pela dedicação à minha formação pessoal, pela amizade, paciência e confiança depositada.

À professora Sheila Ornstein pelas importantes e valiosas contribuições no desenvolvimento deste trabalho e pelo estímulo a buscar novos horizontes.

Ao Rovilson pela amizade, paciência, "puxões de orelha" e pelo apoio "logístico" fundamental.

À Eloisa pela amizade e pelos saudosos bate-papos na POLI, e aos colegas asteroidianos e labcadianos pela convivência estimulante.

Aos tecnólogos, engenheiros, arquitetos, assistentes sociais da UGP, JNS-HAGAPLAN, BETER, HABI-SP, SEHAB e DIAGONAL pelas entrevistas e disposição dos registros documentais necessários à realização da pesquisa.

Aos coordenadores do Programa Guarapiranga Sr. Dirceu Rioji Yamazaki e Sra. Elizabety França pelos valiosos depoimentos e disposição para obtenção dos dados sobre o Programa.

Toda a Comunidade Sete de Setembro, em especial a Sueli e a Maria pela colaboração e apoio para o desenvolvimento da pesquisa.

À CAPES - pelo apoio financeiro à pesquisa.

Aos amigos, Renata, Débora, Malachias e Eloisa pelos estímulos e pela disposição para discussão de assuntos relativos ao estudo; à Rita, à Mara e a Jany pela revisão do texto, à Soraya pelo apoio e execução dos desenhos no CAD e ao Pedro pelo auxílio na coleta de dados em campo.

Aos amigos, conhecidos no CRUSP e que levarei pela vida, Débora, Brow e Adelmo, com quem conheci a solidariedade no momento mais importante da minha vida: o nascimento da minha filha; ao Carlos e Alessandra pelo agradável convívio e os demais cruspianos pela convivência.

À amiga Vidula pelos longos anos de amizade e sinceridade e à Jany por trazer luz à minha vida.

Às minhas queridas irmãs Janete e Janeide e irmãos Josué, Joel, Jônatas, Joab, Douglas, pela compreensão das repetidas ausências e pelo aconchego da família.

À Fátima, à Cristina, à Alcione, ao Rogério, ao Edson e à Patricia pela paciência, pelo apoio e pronto auxílio.

A todos aqueles que contribuíram de alguma forma para a realização deste trabalho.

E, por fim, agradeço à minha grande amiga e companheira Rita pelo amor e dedicação à minha filha Letícia nos momentos de minha ausência. 


\section{Sumário}

Lista de figuras $\quad$ iv

Lista de tabelas $\quad$ v

Resumo vii

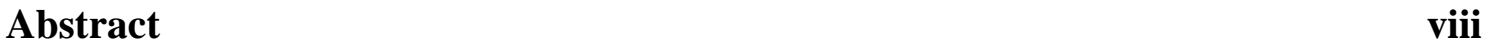

1 Introdução 1

1.1 Introdução . . . . . . . . . . . . . . . . . . . . . . . . . 1

1.2 Objetivo da dissertação . . . . . . . . . . . . . . . 3

1.3 Justificativa ......................... 4

1.4 Organização da dissertação . . . . . . . . . . . . . . . . . . 5

2 Políticas de urbanização de favelas 6

2.1 As políticas alternativas: um novo conceito mundial . . . . . . . . . . 6

2.2 Brasil: o surgimento das favelas e a política adotada . . . . . . . . . . . 7

2.2.1 Favelas em São Paulo: um breve histórico . . . . . . . . . . . 8

2.3 Urbanização de favelas . . . . . . . . . . . . . . . . . . . . 9

3 Descrição do objeto de estudo 13

3.1 Contextualização do problema na Bacia do Guarapiranga . . . . . . . . . 13

3.2 O Programa de Saneamento Ambiental da Bacia do Guarapiranga . . . . 15

3.3 O Subprograma de Recuperação Urbana . . . . . . . . . . . . . . . . . . 19 
3.3.1 A Comunidade Sete de Setembro . . . . . . . . . . . . . . . 19

3.3.2 Diagnóstico da Comunidade Sete de Setembro antes da urbanização 20

3.3.3 Avaliação oficial realizada após a urbanização . . . . . . . . . . 23

4 Método de estudo $\quad 28$

4.1 Conceituação de APO . . . . . . . . . . . . . . . . . . 28

4.2 Avaliação Pós-Ocupação (APO) - Um breve histórico . . . . . . . . . . . 30

4.2.1 A produção Internacional e sua relação com o Brasil . . . . . . . 31

4.3 Fundamentação teórica dos métodos utilizados . . . . . . . . . . . 33

4.3 .1 Observação . . . . . . . . . . . . . . . . . 33

4.3 .2 Entrevistas ....................... 35

4.3.3 Análise documental e dos dados coletados . . . . . . . . . . . . 37

$5 \quad$ Estudo de caso $\quad 38$

5.1 A escolha da área para os estudos . . . . . . . . . . . . . . 38

5.1.1 O levantamento documental . . . . . . . . . . . 38

5.1 .2 As entrevistas . . . . . . . . . . . . . 38

5.1 .3 As visitas técnicas $\ldots \ldots \ldots 39$

5.2 O questionário Piloto . . . . . . . . . . . . . . . . . . 40

5.3 Caracterização da Comunidade Sete de Setembro . . . . . . . . . . . . 44

5.4 Levantamento dos equipamentos sociais e urbanos que atendem a população da Comunidade Sete de Setembro . . . . . . . . . . . . . . . 49

5.4 Educação . . . . . . . . . . . . . . . . . 50

5.4 .2 Equipamentos de esporte e cultura . . . . . . . . . . . . . 50 50

5.4 .3 Abastecimento e Bancos . . . . . . . . . . . . . . 51

5.4 .4 Saúde . . . . . . . . . . . . . . . . . . 51

5.4 .5 Telefones Públicos . . . . . . . . . . . . . 51

5.4.6 Transporte Coletivo . . . . . . . . . . . . . 51

5.4 Limpeza. . . . . . . . . . . . . . . 52

5.4 .8 Segurança Pública . . . . . . . . . . . . . . . 52 
5.4 .9 Correios ........................ 52

5.5 Levantamento do estado de conservação e desempenho das obras realizadas na área . . . . . . . . . . . . . . . . 53

5.6 Levantamento das atividades dos moradores nos espaços exteriores à habitação . . . . . . . . . . . . . . . . . . 55

5.7 Entrevista semi-estruturada com grupos focais . . . . . . . . . . . 59

6 Comentários finais $\quad 66$

$\begin{array}{ll}\text { Referências bibliográficas } & \mathbf{7 2}\end{array}$

$\begin{array}{ll}\text { Anexo } 1 \text { - Lista de materiais encontrados na SEHAB-II } & 77\end{array}$

Anexo 2 - Lista de materiais encontrados no Consórcio JNS-HagaPlan e na Cons$\begin{array}{lr}\text { trutora BETER } & \mathbf{8 0}\end{array}$

Anexo 3 - Lista de materiais encontrados na UGP 81

$\begin{array}{ll}\text { Anexo } 4 \text { - Questionário piloto } & 83\end{array}$

Anexo 5 - Roteiro para coleta de informações junto as instituições 89

Anexo 6 - Planta da Comunidade Sete de Setembro 92

Anexo 7 - Planta com nomenclatura das ruas, fechamento das vielas, porcentagem de obstruções das grelhas e localização dos orelhões públicos

Anexo 8 - Mapeamento das áreas verdes, lixeiras, árvores e pontos de acúmulo de lixo

Anexo 9 - Primeiro mapeamento de atividades realizadas nos espaços públicos

Anexo 10 - Segundo mapeamento de atividades realizadas nos espaços públicos 100 
Anexo 12 - Roteiro semi-estruturado para entrevista coletiva com jovens com base no questionário piloto e observações feitas durante a pesquisa - Comunidade Sete de Setembro

Anexo 13 - Roteiro semi-estruturado para entrevista coletiva com adultos com base no questionário piloto e observações feitas durante a pesquisa - Comunidade Sete de Setembro

Anexo 14 - Fotos da Comunidade antes e depois da urbanização

Anexo 15 - Lista dos equipamentos Sociais e Urbanos que atendem a população da Comunidade Sete de Setembro 


\section{Lista de Figuras}

3.1 Arranjo institucional . . . . . . . . . . . . . . . . . . . 19

3.2 Localização da Comunidade Sete de Setembro . . . . . . . . . . . . . 21

4.1 APO - Ciclo de realimentação do processo de produção e uso. (ORNSTEIN, 1992). . . . . . . . . . . . . . . . . . . . . . . . 29

6.1 Planta da Comunidade Sete de Setembro . . . . . . . . . . . . . . . 93

6.2 Planta com nomenclatura das ruas, fechamento das vielas, porcentagem de obstrução das grelhas e localização dos telefones públicos . . . . . . 9 95

6.3 Mapeamento das áreas verdes, lixeiras, árvores e pontos de acúmulo de lixo 97

6.4 Mapeamento das atividades realizadas nos espaços públicos (19.07.2001) 99

6.5 Mapeamento das atividades realizadas nos espaços públicos (21.07.2001) 101

6.6 Fotos antes da urbanização . . . . . . . . . . . . . . . . 110

6.7 Fotos após a urbanização . . . . . . . . . . . . . . . . . 111

6.8 Localização da Bacia do Guarapiranga . . . . . . . . . . . . . . 118 


\section{Lista de Tabelas}

2.1 Programas voltados às favelas . . . . . . . . . . . . . . . 12

3.1 Recursos do Programa . . . . . . . . . . . . . . . . . . 18

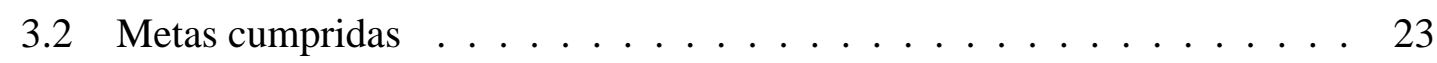

5.1 Quantidade de grelhas obstruídas . . . . . . . . . . . . . 54

5.2 Resultado da entrevista com grupo de jovens . . . . . . . . . . . . 62

5.3 Resultado da entrevista com grupo de adultos . . . . . . . . . . . . 64 


\section{RESUMO}

Este trabalho analisa um projeto de urbanização de favelas, onde foi implantado o Programa de Saneamento Ambiental da Bacia do Guarapiranga, localizado na Região Sudoeste da Região Metropolitana de São Paulo (RMSP). O local selecionado para o estudo é conhecido como a Comunidade Sete de Setembro, instalada numa área de proteção aos mananciais e pertencente à SubPrefeitura de Capela do Socorro. No estudo do referido caso, adotou-se o método denominado Avaliação Pós-Ocupação (APO) que se constitui num conjunto de métodos e técnicas, aplicado em ambientes já construídos e já ocupados. Foi analisado como o usuário se apropriou das benfeitorias promovidas no local e apresentado o grau de satisfação dos moradores em relação às intervenções efetuadas. 


\begin{abstract}
SLUM (FAVELA) UPGRADING AT A PROTECTED AREA FOR WATER CATCHMENT: THE CASE OF THE COMUNIDADE SETE DE SETEMBRO.

This work analyses a slum (favela) upgrading project which is part of the action plan of the Programa de Saneamento Ambiental da Bacia do Guarapiranga (Program of Environmental Sanitation of the Guarapiranga Basin), located in the Southeast region of São Paulo's Metropolitan Area. The slum selected for this case is known as Comunidade Sete de Setembro. It is located in a protected area for water catchment and belongs to the Borough of Capela do Socorro. In the study a Post-Occupancy Evaluation (POE) methodology was used. This method consists on the application of a series of methods and techniques in applied research of built environments which are in use. It analyses mainly how the user is appropriating the intervention. This work presents the satisfaction of the residents regarding the upgrading interventions performed.
\end{abstract}




\section{Capítulo 1}

\section{Introdução}

\subsection{Introdução}

A rápida urbanização nos países em desenvolvimento começou a tomar dimensões significativas a partir da década de cinqüenta. Foi verificado um número cada vez maior de pessoas deslocando-se do campo para as cidades, com uma elevação da população urbana. Em decorrência desses acontecimentos puderam-se observar mudanças significativas no modo de vida dos habitantes das cidades. Esses procuraram inserir-se no setor produtivo da economia, na tentativa de melhorar a qualidade de vida. Tal inserção contribuiu para a economia das cidades, mas resultou em outros problemas, tais como o fato de os migrantes não conseguirem emprego e entrarem no mercado informal. Boa parte da população começou a viver em áreas desprovidas de qualquer tipo de infra-estrutura básica e de serviços, denominadas favelas ${ }^{1}$.

O Brasil é um exemplo típico do quadro apresentado. Com um grande nível de desigualdade social, enfrenta graves problemas nas áreas sociais e principalmente na área de habitação popular. Em 1995, segundo dados divulgados pela Fundação João Pinheiro de Belo Horizonte - MG, o Brasil possuía um déficit habitacional de 5,6 milhões de moradi-

\footnotetext{
${ }^{1}$ Adotou-se como definição de favela "o conjunto de unidades domiciliares, construídas de madeira, zinco, lata, papelão ou até mesmo em alvenaria, distribuídas desordenadamente em terrenos cuja propriedade individual do lote não é legalizada para aqueles que os ocupam. Na maioria das vezes ocupam áreas com declividade acentuada ou inundáveis"(ABIKO, 1995).
} 
as, sendo 4 milhões em áreas urbanas e 1,6 milhões na zona rural. O déficit apontava para um quadro de 22 milhões de pessoas morando em habitações precárias em todo o país.

Neste contexto se evidencia um crescimento cada vez maior da cidade informal (assentamentos humanos com habitações precárias edificadas em áreas públicas ou privadas, não atendendo à legislação urbanística nem ao código de edificações). É para esta denominada cidade informal que programas financiados por agências internacionais e políticas têm sido implementados nas várias esferas governamentais. O Brasil vem trabalhando neste setor através da implementação de diversos programas em várias capitais, como Belo Horizonte, Rio de Janeiro, Recife, Salvador e São Paulo.

Percebe-se que nas sucessivas gestões do poder público municipal da Região Metropolitana de São Paulo há diversos projetos com o objetivo de recuperar as áreas onde se localizam as favelas. Como exemplos pode-se citar o projeto Cingapura, com a verticalização de favelas, e também a Urbanização do Programa de Recuperação Ambiental da Bacia do Guarapiranga, alvo de pesquisa deste trabalho.

Durante visitas realizadas às favelas que estavam sendo urbanizadas pelo referido Programa, percebeu-se que os problemas existentes nestas áreas ultrapassavam as questões da implantação física propriamente dita.

No campo de pesquisa da engenharia, entender como foi concebido o Programa e a complexidade dos aspectos a ele relacionados é bastante proveitoso, pois o pesquisador necessita voltar seu olhar um pouco mais para o âmbito social. Consideramos esse fator importante, à medida que podemos formar agentes melhor preparados para atuar na resolução dos problemas urbanos.

O Programa é uma experiência inédita em São Paulo, e conseguiu reunir em torno dele representantes do governo, prefeituras, iniciativa privada, agência internacional de financiamento e a sociedade civil, com o intuito de eliminar os mais variados problemas, tais como os ambientais, de saúde, educação, gestão do meio de maneira sustentável, entre 
outros.

O Programa Guarapiranga foi estruturado em cinco Sub-programas, um deles denominado Recuperação Urbana, em que se incluem os serviços de urbanização de núcleos de favelas. Os núcleos compõem-se de aproximadamente 180 (cento e oitenta) favelas que foram subdivididas em Lotes. Cada um desses Lotes é composto por diversas favelas, que estão sendo urbanizadas, como é o caso da Sete de Setembro, estudada neste trabalho e pertencente ao Lote I. Este Lote, composto por sete favelas, foi o primeiro a ser urbanizado.

A favela, inaugurada em 1996, depois da sua urbanização recebe a denominação de Comunidade Sete de Setembro, e a partir deste momento será chamada desta forma neste trabalho. Pressupõe-se neste trabalho que a população já tenha um tempo de vivência e experiências nas áreas modificadas, portanto pode retratar de forma realista as mudanças que tal intervenção provocou em seu cotidiano. Além do tempo, a forte participação social e a organização comunitária foram fatores sempre lembrados positivamente pelos engenheiros, técnicos e assistentes sociais que participaram da execução da urbanização da referida área. Além disso, em visitas a outras favelas que foram urbanizadas em período próximo à conclusão da Sete de Setembro, percebemos que as obras desta em relação às outras estavam em melhor estado de conservação. Daí surge uma pergunta: Será a organização comunitária a responsável por este fato? Se isso ocorre, é interessante apresentar neste trabalho de que forma isso ocorreu.

\subsection{Objetivo da dissertação}

O objetivo da presente dissertação de mestrado é analisar um projeto de urbanização de favela em área de proteção de mananciais. Para tanto foi escolhida a Comunidade Sete de Setembro, que faz parte do Programa de Recuperação Ambiental da Bacia do Guarapiranga (PRBG). Este estudo procura retratar o grau de satisfação dos moradores em relação às intervenções efetuadas através do Método de Avaliação Pós-Ocupação (APO). 


\subsection{Justificativa}

O desenvolvimento dessa pesquisa se justifica pela necessidade de refletirmos sobre a forma que vêm sendo implementados projetos de intervenção em favelas, os benefícios trazidos por cada projeto e a satisfação da população atendida.

Destaca-se, ainda, cumprir o papel social que a universidade tem em desenvolver estudos voltados para a realidade da população brasileira, contribuindo, assim, com a elevação da sua qualidade de vida.

Há uma escassa bibliografia sobre o tema em questão, podendo-se citar as pesquisas de VALLADARES (1985) e de SAMPAIO (1998) que discutem a questão em âmbito nacional. Nesta pesquisa constata-se que diversas experiências em projetos alternativos para habitação popular não estão sendo acompanhadas e nem avaliadas dentro de uma análise sistemática. No entanto, merece destaque a atuação do Departamento de Engenharia de Construção Civil da Escola Politécnica da Universidade de São Paulo, que continuamente vem contribuindo para a amenização de tal quadro com a produção de pesquisas nesse campo. Podemos mencionar os trabalhos elaborados pelo pesquisador ALMEIDA (1994), que apresenta sua dissertação intitulada Urbanização de Favelas em Diadema, no período de 1993 a 1998, e em 1999 defende uma tese de doutorado intitulada Indicadores de Salubridade Ambiental em Favelas Urbanizadas: o caso de favelas em áreas de proteção ambiental. O outro trabalho dentro desta linha apresentado neste Departamento foi o de PEREIRA (2001), com a dissertação intitulada Intervenção em Favelas no Município de São Paulo Através do Projeto Cingapura: O Conjunto Zaki Narchi.

A importância do tema na atualidade, é mencionado no trabalho da pesquisadora SAMPAIO (1998), que vê no desenvolvimento de pesquisas a constribuição para resolução dos problemas urbanos, principalmente nas metrópoles dos países em desenvolvimento, onde a pobreza e o crescimento populacional têm caminhado em conjunto.

Revisando a literatura verifica-se um inexpressivo número de pesquisas acadêmicas envolvendo APO em favelas urbanizadas. O único trabalho encontrado, até o momento, 
é a dissertação de CRUZ (1998), com a dissertação intitulada Avaliação Pós-Ocupação (APO) dos espaços gerados em habitações autoconstruídas: o caso da favela Nossa Senhora Aparecida em São Miguel Paulista, São Paulo. Neste trabalho é dado um maior enfoque para os aspectos técnicos dimensionais das habitações.

\subsection{Organização da dissertação}

A dissertação é constituída basicamente de seis capítulos. O capítulo um refere-se às questões de contextualização do tema proposto, bem como às questões relacionadas ao seu desenvolvimento, aos principais objetivos a serem atingidos e à organização do trabalho. No capítulo dois, procura-se fazer uma revisão histórica do tema urbanização de favelas. O capítulo três apresenta o histórico e a estruturação do Programa Guarapiranga, bem como do projeto específico de urbanização da Comunidade Sete de Setembro. No capítulo quatro, apresenta-se a fundamentação teórica dos métodos utilizados na pesquisa de campo. No capítulo cinco, o estudo de caso é apresentado com análises, e conclui-se esta dissertação no capítulo seis com recomendações e comentários finais. 


\section{Capítulo 2}

\section{Políticas de urbanização de favelas}

\subsection{As políticas alternativas: um novo conceito mundial}

Segundo VALLADARES (1985), um conjunto de fatores intimamente interligados fez com que, a partir da década de 60, inúmeros governos políticos passassem a adotar um novo tipo de atitude para enfrentar os aglomerados espontâneos e de ocupação irregular que se espalhavam no interior das grandes cidades do Terceiro Mundo. Deixando de lado as tentativas de prover habitação popular por meio de programas de remoção e construção de conjuntos habitacionais padronizados, muitos países passaram a implementar políticas numa nova direção: seja no sentido de consolidar as áreas de ocupação irregular já existentes, seja no de preparar áreas para futuras ocupações. Tais proposições geraram dois tipos básicos de propostas que, na verdade, caminham juntas: a) o settlement upgrading, que envolve a urbanização de áreas já ocupadas, mas carentes de infra-estrutura e equipamentos coletivos. Tal proposta, além de estender os serviços públicos às áreas tipo favela, também prevê a regularização da ocupação por meio de instrumentos jurídicos especiais que levam à segurança da posse do solo urbano, b) o site and services, que corresponde à oferta de loteamentos dotados de traçado regular e equipados com o mínimo de infraestrutura básica, o chamado lote urbanizado. A ocupação de tais espaços se dá de forma orientada e dirigida pela venda dos lotes a preços acessíveis. Em ambas as propostas, a construção das moradias é responsabilidade da população, bem como é prevista a sua par- 
ticipação no trabalho de implantação dos equipamentos coletivos, e também nos projetos de maneira global.

"A introdução dessas políticas representou uma ruptura com práticas anteriores de urbanismo e planejamento habitacional, bem como uma certa concepção de como lidar com a questão dos países em acelerado processo de urbanização"(VALLADARES, 1985).

No meio acadêmico, atribui-se ao arquiteto John Turner apud VALLADARES (1985) a mais contundente defesa das áreas de ocupações irregulares vistas como espaços a serem preservados. Em um trabalho encomendado pelas Nações Unidas em 1960, intitulado "Uncontrolled Urban Settlements: problems and policies", o autor, a partir de uma extensa bibliografia internacional, estende suas conclusões aos demais países do terceiro mundo, mostrando que as áreas de ocupação irregular devem ser consideradas como uma expressão normal do processo de crescimento urbano, tendo em vista as condições excepcionais em que vem se processando a urbanização. Na conclusão do trabalho, sugere a implantação de políticas que levem à consolidação destas áreas, pelo suprimento de serviços básicos como água, esgoto e a garantia da posse da terra. As idéias do arquiteto foram rapidamente apropriadas e disseminadas pelas agências internacionais de financiamento ao desenvolvimento urbano.

\subsection{Brasil: o surgimento das favelas e a política adotada}

\footnotetext{
"As primeiras favelas aparecem em São Paulo no início da década de 40. Contudo, o fenômeno da favelização só vai se desenvolver em larga escala nos anos 70"(TASCHNER, 1998).
}

Segundo VALLADARES (1985) no Brasil, os programas alternativos para tratar da habitação popular começaram em 1975 com o PROFILURB - programa de lotes urbanizados - criado pelo BNH. Em 1979, foi criado o PROMORAR - voltado para urbanizar áreas do tipo favela. Finalmente, em 1983, foi lançado o JOÃO DE BARRO, destinado a financiar 
a autoconstrução, observando-se a sua rápida propagação desde o início dos anos 80, tanto pelo Banco Nacional de Habitação (BNH), como nas esferas estadual e municipal, por iniciativa de seus respectivos governos.

"Os favelados não são mais assunto de polícia e sujeitos a remoção forçada, ou migrantes incultos, incapazes tutelados pelo poder público nas vilas de habitação provisória ou parques proletários (...) Desmarginalizaram-se os moradores da terra invadida". "Os programas de urbanização, melhoria das unidades habitacionais e promessas de regularização da posse da terra tranqüilizam a população invasora, que investe no seu habitat, tornando-o permanente"(TASCHNER, 1998).

\subsubsection{Favelas em São Paulo: um breve histórico}

VÉRAS; TASCHNER (1990) afirmam que "o enorme incremento das favelas no município de São Paulo ocorrido nas últimas décadas não se deu uniformemente pela cidade". Segundo SAMPAIO (1998), a favela possui as seguintes características: desde o seu inicio, já é lugar sujeito a preconceito, discriminação e símbolo da segregação. A área em torno da favela é, na maioria das vezes, ocupada por população de classe média baixa, e o padrão predominante das casas dessa vizinhança é a autoconstrução. Muitas vezes tem-se o núcleo inicial da habitação, a partir do qual foram adicionados os demais cômodos, sem nenhuma ordem previamente estabelecida. Esses acréscimos dependem não só do desejo do morador de ter mais espaço, mas de razões variadas. De fato, o crescimento da família ou a necessidade de abrigar mais um parente que chega, uma filha ou filho que se casa, fazem com que a casa vá crescendo, limitada pela expansão dos vizinhos, que por sua vez vão aumentando suas casas pelas mesmas razões.

O resultado são quadras onde praticamente inexistem áreas livres, onde cada habitação está geminada à outra, e onde, com freqüência, encontram-se até habitações que não possuem acesso direto para a rua. Para chegar-se a essas casas passa-se por outro terreno, ou por vielas estreitas, que chegam a ter $80 \mathrm{~cm}$ de largura. Nos últimos anos, como tendência, 
tem-se assistido à verticalização nas favelas de São Paulo, ou seja, à construção de casas com mais andares, de dois a quatro. A exiguiidade de terrenos faz com que a possibilidade de aumento só ocorra com a construção de mais um andar.

TASCHNER (1998) acrescenta mais algumas características das áreas de favelas: 50,5\% das casas são de alvenaria, houve melhoria das condições de vida do contingente favelado paulistano, tendo agora acesso à energia e água domiciliar com tarifa mínima e direito à coleta de lixo. Segundo pesquisas de 1987 (censo de favelas), o favelado não é apenas migrante e nem sempre a favela é seu primeiro local de moradia nas áreas urbanas. A trajetória mais frequiente parece ser da casa alugada para a favela. Verifica-se que uma grande parcela dos chefes de família trabalham no setor terciário; verifica-se, ainda, que a distinção entre o chefe favelado e o restante da classe trabalhadora está no fato de ter ele, predominantemente, ocupação manual semi ou não especializada. Tem-se mais da metade dos chefes categorizados como analfabetos funcionais.

\subsection{Urbanização de favelas}

Segundo WERNA et al. ( 2001), os programas de urbanização de favelas resultam em padrões habitacionais de melhor qualidade em relação à estrutura encontrada nos assentamentos informais inicialmente. Tais programas de urbanização são baseados em projetos específicos ou então podendo em alguns casos constituir uma parte do processo de planejamento físico geral das áreas urbanas do país ( SALLEN, 1983 apud WERNA et al. 2001). No mundo normalmente o financiamento e organização dos projetos vem de agentes internacionais; no entanto, em alguns casos os governos locais os executam independentemente. "Atualmente os projetos de urbanização são elaborados prevendo as intervenções urbanísticas nas áreas, privilegiando a adoção de soluções voltadas ao alargamento e ao alinhamento das vias internas, visando criar condições para a implantação de infra-estrutura e dos serviços urbanos. Pode-se prever que com essa urbanização e sua integração à estrutura dos bairros existentes, os efeitos negativos advindos da condição 
precária das favelas deixarão de existir, gerando uma valorização tanto dos imóveis da favela como das áreas circunvizinhas"(ALMEIDA, 1999).

"Os programas de urbanização de favela vigente desde 1979 no município de São Paulo conseguiram que, em 1993, 90\% das moradias faveladas estivessem ligadas à rede pública de energia elétrica, $88,4 \%$ tivessem coleta de lixo e 64,2\% tivessem água encanada, com ligação domiciliar (...) de outro lado, a ausência de infra-estrutura sanitária torna-se dramática, com 77,1\% dos domicílios em 1993 lançando dejetos ao ar livre e/ou diretamente a córregos ou represas (...) representando um montante de mais de 290 mil moradias"(TASCHNER, s.d).

"A urbanização de favelas é um projeto que necessita uma participação da comunidade, de forma intensa e articulada. Sem dúvida são os moradores das favelas que tem as melhores condições de conhecimento da comunidade, do sítio ocupado, de suas necessidades e prioridades"(ABIKO, 1995).

Segundo ABIKO (1995) os projetos de urbanização de favelas podem ser desenvolvidos em quatro etapas fundamentais. São elas:

1- Estudo preliminar: Etapa fundamental para a tomada de decisão da viabilidade técnica, física e jurídica de se implementar um projeto de urbanização da área escolhida. Nesta etapa também ocorrerá o primeiro contato com os moradores da região.

2- Cadastramento: Uma vez verificada a possibilidade de se implantar um projeto de urbanização, os moradores da área deverão ser cadastrados. Para evitar um aumento da população desta área (que vai ser beneficiada com a urbanização) o melhor é que a população da área faça o cadastramento definindo as famílias a serem beneficiadas.

3- Projeto: A área escolhida será loteada para acomodar o maior número de famílias cadastradas da melhor forma possível com um lote para cada família provido de água, energia elétrica, vias de circulação interna, instalação telefônica e esgoto assim como os espaços necessários para as concessionárias implementarem estes sistemas. Para tanto, é 
preciso modelar o projeto de maneira a atender as variáveis acima de maneira mais eficaz. 4- Execução: O tempo de execução do projeto varia de acordo com as condições geográficas da área escolhida e da disponibilidade financeira dos moradores em auxiliar na construção civil das casas. Se o terreno for plano e de fácil acesso, o projeto será implantado mais rapidamente do que em terrenos de acesso difícil. Este tempo pode variar de alguns meses a alguns anos.

Na tabela 2.1 está resumido um levantamento apresentado por PEREIRA (2001) dos principais programas do poder público voltado às favelas. Um levantamento mais aprofundado das ações brasileiras relacionadas à remoção e/ou urbanização pode ser visto em ABIKO (1995). 
Tabela 2.1: Programas voltados às favelas

\begin{tabular}{|c|c|c|c|c|}
\hline \multicolumn{5}{|c|}{ Programas voltados às favelas } \\
\hline Local & Nome do Programa & Período & Conduta adotada & Observações \\
\hline \multirow{4}{*}{$\overline{\bar{c}}$} & PRÓ-MORAR & 1979 & $\begin{array}{l}\text { Regularização fundiária e troca } \\
\text { de barracos por unidades embrião } \\
\text { de alvenaria. }\end{array}$ & \\
\hline & HABITAR BRASIL & 1993 & Dentre outros, urbanizar favelas. & \\
\hline & PRÓ-MORADIA & 1995 & Dentre outros, urbanizar favelas. & \\
\hline & PROSANEAR & 1995 & $\begin{array}{l}\text { Oferecer condições de } \\
\text { saneamento em áreas degradadas. }\end{array}$ & \\
\hline \multirow{2}{*}{ 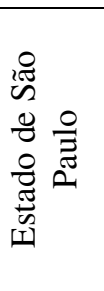 } & PROJETOS ESPECIAIS & 1995 & $\begin{array}{l}\text { Urbanizar favelas, substituir } \\
\text { moradias, reassentamento de } \\
\text { apoio a obras públicas, } \\
\text { reestruturação urbana. }\end{array}$ & \\
\hline & $\begin{array}{l}\text { RECUPERAÇÃO DA } \\
\text { BACIA DO } \\
\text { GUARAPIRANGA } \\
\end{array}$ & 1992 & Dentre outros, urbanizar favelas. & \\
\hline \multirow{8}{*}{ 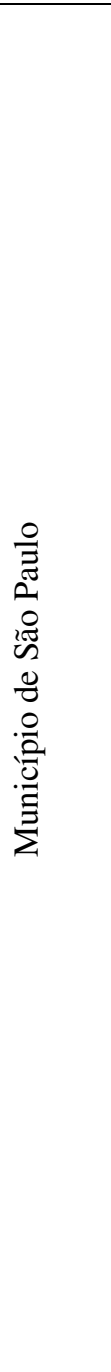 } & & 1973 a 1975 & Não atenção às favelas. & \multirow[b]{2}{*}{$\begin{array}{l}\text { Remoção de } \\
\text { favelas para } \\
\text { núcleos } \\
\text { habitacionais } \\
\text { periféricos, de } \\
\text { difícil acesso. }\end{array}$} \\
\hline & SEHAB & 1975 a 1979 & $\begin{array}{l}\text { Urbanizar favela com } \\
\text { implantação de água, esgoto, } \\
\text { energia elétrica e coleta de lixo } \\
\text { Obs: Pouco foi feito em relação } \\
\text { às favelas }\end{array}$ & \\
\hline & $\begin{array}{l}\text { PRÓ-ÁGUA; PRÓ- } \\
\text { LUZ; PRÓ-FAVELA }\end{array}$ & 1979 a 1982 & $\begin{array}{l}\text { Implantação de rede } \\
\text { água;distribuição de energia } \\
\text { elétrica; instalação de infra- } \\
\text { estrutura, serviços de educação e } \\
\text { saúde, financiamento para } \\
\text { melhoria ou construção de novas } \\
\text { habitações. }\end{array}$ & \begin{tabular}{|l} 
Construção em \\
massa de \\
moradias \\
populares e \\
urbanização de \\
favelas, com \\
implantação de \\
água, esgoto, \\
energia elétrica \\
e coleta de lixo.
\end{tabular} \\
\hline & $\begin{array}{c}\text { PROGRAMA } \\
\text { ESPECÍFICO PARA } \\
\text { URBANIZAR FAVELA }\end{array}$ & 1983 a 1985 & $\begin{array}{l}\text { Implantação de infra-estrutura } \\
\text { básica, não regularização } \\
\text { fundiária. }\end{array}$ & \begin{tabular}{|l|} 
Registrados \\
inúmeros \\
loteamentos \\
clandestinos
\end{tabular} \\
\hline & $\begin{array}{l}\text { OPERAÇÕES } \\
\text { INTERLIGADAS }\end{array}$ & 1986 a 1988 & $\begin{array}{l}\text { Doação de Habitações de } \\
\text { Interesse Social (HIS), destinadas } \\
\text { à população favelada, Remoção } \\
\text { de favelas. }\end{array}$ & $\begin{array}{l}\text { Remoção de } \\
\text { favelas }\end{array}$ \\
\hline & FUNAPS & 1989 a 1992 & $\begin{array}{l}\text { Urbanizar favelas com } \\
\text { participação comunitária, } \\
\text { verticalização de algumas favelas, } \\
\text { não regularização fundiária. }\end{array}$ & $\begin{array}{l}\text { Integração de } \\
\text { moradores de } \\
\text { favela e } \\
\text { cortiços na } \\
\text { trama urbana } \\
\end{array}$ \\
\hline & PROVER & 1993 a 1996 & Verticalização de favelas. & \\
\hline & PROVER & 1997 a 2000 & iden & $\begin{array}{l}\text { Integração de } \\
\text { moradores de } \\
\text { favelas na } \\
\text { trama urbana }\end{array}$ \\
\hline
\end{tabular}




\section{Capítulo 3}

\section{Descrição do objeto de estudo}

\subsection{Contextualização do problema na Bacia do Guarapi- ranga}

A ocupação da Bacia do Guarapiranga iniciou-se na década de sessenta, quando passou a receber um elevado contingente de pessoas atraídas pela proximidade ao setor industrial da região e, posteriormente, pelos setores imobiliário e de serviços.

Segundo os dados da Unidade de Gerenciamento do Programa -UGP (UGP,1997) a população da porção sul, abrangendo a região de Guarapiranga, aumentou, entre 1961-1991, de 176 mil para 2,9 milhões de habitantes, representando um incremento de $7 \%$ ao ano. Nesta vivem cerca de 548 mil pessoas ocupando áreas de baixo padrão habitacional, em favelas ou loteamentos clandestinos.

Ainda nos anos 70, na tentativa de frear e controlar o crescimento nas áreas de mananciais, o poder público estadual elaborou uma legislação para a proteção dos recursos hídricos propondo uma rígida regulação da ocupação e uso do solo. Passados mais de 20 anos, verificam-se, como resultados positivos dessas medidas, a não verticalização e o impedimento da instalação de indústrias nos locais. No entanto a falta de fiscalização facilitou a ocupação descontrolada da área, que apresenta uma densidade superior ao permitido pela 
Lei $\mathrm{n}^{0} 1.172 / 76$ que cria para as áreas de proteção de mananciais categorias para uso e ocupação do solo, estabelecendo densidades máximas conforme a sua categoria.

Segundo dados da UGP(1997), a área da Bacia do Guarapiranga tem $639 \mathrm{~km}^{2}$ e situase na parte sudoeste da RMSP. Compreende parcela do território dos municípios de São Paulo, Embu, Itapecerica da Serra, toda a extensão de Embu-Guaçu e também pequenas porções dos municípios de Cotia, São Lourenço da Serra e Juquitiba (ver anexo 16).

A represa Guarapiranga possui capacidade de acumular aproximadamente 180 milhões de $m^{3}$ de água. A SABESP retira $12 \mathrm{~m}^{3} / \mathrm{s}$ de água para o consumo de aproximadamente 3 milhões de pessoas, correspondendo a 20\% do abastecimento da RMSP, ocupando a posição de segunda maior produtora de água para o abastecimento da Grande São Paulo.

Em 1991, aproximadamente $18 \%$ da população (cerca de 100 mil pessoas) moravam em favelas situadas na margem da bacia. Na porção pertencente ao município de São Paulo, concentravam-se mais de 180 núcleos de favelas. Em 1992, os loteamentos clandestinos, constantes em processos jurídicos na prefeitura de São Paulo, eram 119.

Dadas as características da expansão urbana e a velocidade como essa se deu, não houve possibilidade de o poder público acompanhar as mudanças, ou mesmo fornecer infraestrutura básica e serviços necessários para atender a demanda existente. Como conseqüência disso, em 1992, quando o Programa Guarapiranga foi formulado, a área apresentava o seguinte quadro:

A rede de esgoto atingia apenas $45 \%$ da população, sendo excluída a maioria das favelas, portanto o esgoto das favelas era direcionado diretamente para a bacia; havia coleta regular de lixo que, porém, não atendia todas as favelas em virtude da dificuldade de acesso, além de problemas de destinação final do lixo nos municípios de Embu, Itapecerica da Serra, Embu-Guaçu e Cotia, totalizando 240 toneladas de resíduos coletados, das quais cerca de 210 toneladas eram dispostas em lixões dentro da própria Bacia, problemas relativos a macro e micro-drenagem e a erosão de encostas também foram encontrados. 
As dificuldades causadas pelos problemas apontados provocaram uma gradativa deterioração da qualidade da água nos tributários e na represa. Os monitoramentos realizados pela SABESP e CETESB detectaram acréscimo nas concentrações totais de fósforo e nitrogênio, substâncias altamente prejudiciais por intensificarem problemas relacionados à eurotrofização e à floração algal.

\subsection{O Programa de Saneamento Ambiental da Bacia do Guarapiranga}

O programa Guarapiranga foi formulado por um grupo de atores sociais (representantes do estado, municípios e da sociedade civil), para tratar dos diversos problemas relacionados ao meio ambiente urbano da cidade de São Paulo. Houve a preocupação em se investigar os principais problemas da bacia, dando maior ênfase aos aspectos políticos, incentivando a participação da sociedade.

A participação das comunidades e das organizações, incluindo as Ongs, passou a ser considerada, nas agendas das comunidades de ajuda internacional, como fundamental no processo de desenvolvimento. Para a nova política ser implementada, ou seja, dar maior ênfase aos aspectos sociais e humanos, tais agências reformularam seus mecanismos de financiamento, permitindo uma maior flexibilidade e um suporte efetivo em programas nacionais.

O Banco Mundial é um organismo de ajuda internacional que apresenta restrições para empréstimos e, prioriza o financiamento em países cujos programas tenham consonância com as suas agendas.

A política adotada pelo Banco Mundial em sua agenda para os anos noventa estimula: promover o fortalecimento da capacidade dos governos e instituições locais, a participação da sociedade civil e organizações para detectar e enfrentar seus próprios problemas, dentro de uma visão global, estimulando desta forma a atuação integrada e continuada da 
resolução dos problemas existentes na cidade, podendo, assim, alcançar o desenvolvimento sustentável. Dessa forma, o Programa procurou colocar em prática em sua formulação tais aspectos apontados pelas agências.

O Programa de Saneamento Ambiental da Bacia do Guarapiranga (PSBG) foi criado pelo Governo Estadual, poder Municipal de São Paulo e algumas instituições interessadas na preservação do manancial como fonte de abastecimento para parte da população da RMSP (Ver fig. 3.1).

Esse Programa tem como prerrogativa mitigar as consequiências negativas da ocupação e do uso do solo nas proximidades da bacia, e na definição e operação de mecanismos que possibilitem a reordenação da ocupação urbana.

Os objetivos específicos do Programa são o desenvolvimento da a capacitação técnica, financeira e institucional para a gestão da Bacia, dentro dos padrões sustentáveis, ou seja, a facilitação de um equilíbrio entre as várias esferas governamentais, privadas e populares, e a melhoria da qualidade de vida da população residente nessas áreas.

Para o cumprimento dos objetivos propostos pelo Programa foram estruturados cinco subprogramas:

\section{Serviços de Água e Esgotos:}

- Ampliação do sistema de coleta e afastamento de esgotos atendendo a mais de $80 \%$ da população residente;

- Melhorias operacionais nos sistemas de coleta existentes;

- Desvio das cargas poluidoras afluentes da represa pelos córregos Guavirutuba e Itupu;

- Aprimoramento no processo de tratamento de água por meio de utilização de novos processos e tecnologias.

\section{Coleta e Disposição de Lixo:}


- Adequação e controle ambiental do sistema de coleta, tratamento e disposição final de resíduos sólidos nos municípios de Embu, Itapecerica da Serra e Embu-Guaçu;

- Aquisição de equipamentos de coleta e limpeza pública para as prefeituras desses mesmos municípios.

\section{Recuperação Urbana:}

- Urbanização de núcleos de favelas, atendendo aproximadamente 25.000 famílias, incluindo a estabilização de encostas, drenagem e redes de água e esgotos;

- Remoção e reassentamento de famílias residentes em favelas, em áreas de risco ou sem condições de esgoto sanitário;

- Adequação da infra-estrutura viária e de drenagem em áreas urbanas degradadas, visando a contenção de erosão e a garantia de acesso à coleta de lixo.

\section{Proteção Ambiental:}

- Repovoamento vegetal das margens da represa e das faixas de domínio público, recuperação de matas ciliares e arborização urbana;

- Implantação de 6 parques;

\section{Gestão da Bacia:}

- Elaboração de estudos visando a organização da gestão da bacia, incluindo um Plano Diretor para o desenvolvimento e proteção ambiental do seu território e a criação de um sistema de informação gerencial digitalizado;

- Educação ambiental e capacitação técnica para gestão;

- Operacionalização da gestão por meio do esforço à fiscalização integrada e da criação de um sistema de informações gerenciais sobre a bacia. 
Para a coordenação do Programa, foi criada a Unidade de Gerenciamento do Programa (UGP), sediada na Secretaria de Recursos Hídricos, Saneamento e Obras de Governo do Estado de São Paulo.

A Prefeitura do Município de São Paulo, a Secretaria do Meio Ambiente do Estado (SMA), a Companhia de Desenvolvimento Habitacional e Urbano (CDHU) e a SABESP são responsáveis pela execução das obras, estando todas subordinadas ao Governo do Estado de São Paulo.

As responsabilidades operacionais, relativas à infra-estrutura e aos equipamentos que serão implantados no decorrer do programa, nos municípios de Embu, Itapecerica da Serra e Embu-Guaçu, ficam a cargo de suas respectivas prefeituras.

A estrutura organizacional do Programa prevê um Conselho Consultivo tripartite, constituído por 14 representantes do estado, 14 dos municípios e 14 da sociedade civil, totalizando 42 membros. Ver anexo 11.

O orçamento previsto preliminarmente para o Programa é de US\$262 milhões (duzentos e sessenta e dois milhões de dólares). O BIRD é o responsável pelo financiamento de $45 \%$ do valor estipulado, e o restante é responsabilidade das demais instituições participantes, como pode ser visto na tabela que segue. Cabe ressaltar que o financiamento foi assinado pelo Governo do Estado em 17/12/1992.

Tabela 3.1: Recursos do Programa

\begin{tabular}{c|c|c|c|c|c|c}
\hline \hline Executor & \multicolumn{2}{|c|}{ BIRD } & \multicolumn{2}{c|}{ Contrapartida } & \multicolumn{2}{c}{ Total } \\
\hline & Valor & $(\%)$ & Valor & $(\%)$ & Valor & $(\%)$ \\
\hline \hline UGP & 21,430 & 18 & 10,245 & 7,2 & 31,675 & 12,1 \\
\hline SABESP & 36,682 & 30,8 & 39,801 & 27,8 & 76,483 & 29,2 \\
\hline CDHU & 17,237 & 14,5 & 39,088 & 27,3 & 56,325 & 21,5 \\
\hline SMA & 10,518 & 8,8 & 15,544 & 10,9 & 26,062 & 9,9 \\
\hline PMSP & 33,133 & 27,8 & 38,254 & 26,8 & 71,387 & 27,3 \\
\hline \hline Total & $\mathbf{1 1 9 , 0 0}$ & $\mathbf{1 0 0 , 0 0}$ & $\mathbf{1 4 2 , 9 3 2}$ & $\mathbf{1 0 0 , 0 0}$ & $\mathbf{2 6 1 , 9 3 2}$ & $\mathbf{1 0 0 , 0 0}$ \\
\hline \hline
\end{tabular}


A composição e a estruturação dos organismos participantes do Programa podem ser vistas na Figura a seguir.

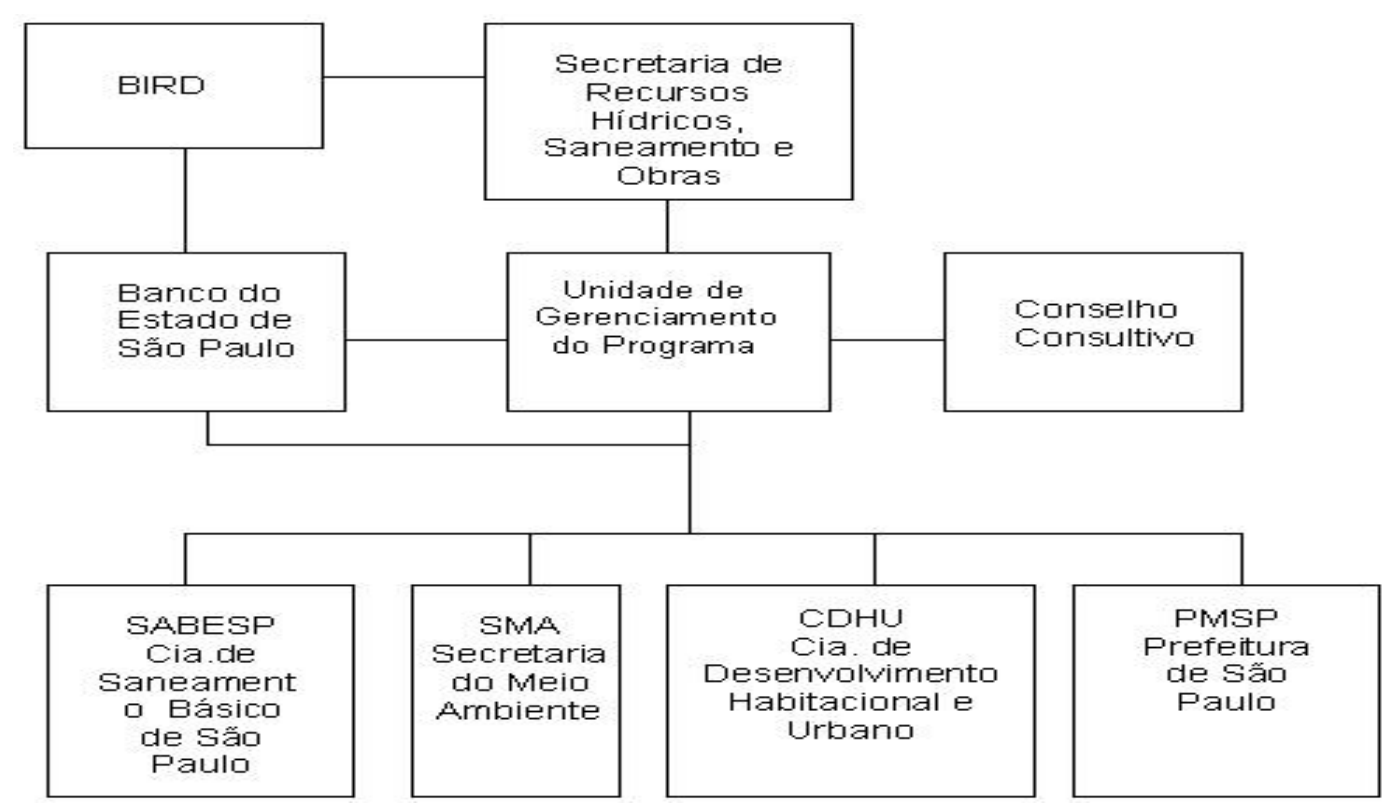

Figura 3.1: Arranjo institucional

\subsection{O Subprograma de Recuperação Urbana}

O Subprograma III contempla as atividades de urbanização de favelas, adequação de infraestrutura viária e drenagem em loteamentos de baixa renda, situados, normalmente, em áreas contíguas às favelas. Em relação à urbanização de favelas, ainda está previsto o reassentamento da população que sofreu interferências no decorrer de sua implantação, para conjuntos habitacionais construídos em áreas bem servidas por transporte e equipamentos públicos.

\subsubsection{A Comunidade Sete de Setembro}

A Comunidade Sete de Setembro, está situada na faixa direita da Av. Senador Teotônio Vilela, em uma área que divide os Bairros N. Sra. Aparecida e Jd. São Francisco. A 
Comunidade tem como principal via de acesso a Rua Aureliano de Beruete no Bairro Jardim São Bernardo, pertencente à região administrativa da Capela do Socorro ${ }^{1}$ (Ver figura 3.2).

Para o desenvolvimento das obras, as favelas foram agrupadas, e cada grupo recebeu o nome de Lote (O Lote I é constituído por 7 Favelas). A favela em estudo pertence a este primeiro Lote de favelas urbanizadas no Subprograma. As primeiras favelas inauguradas foram São José IV, Jardim Alpino e Presidente/Jordanópolis. A obras de urbanização da Comunidade Sete de Setembro foram entregues em meados 1996, no mesmo período da Jardim Souza, Santa Lúcia II e Jardim das Imbuias.

A escolha da área para o estudo baseou-se na facilidade na obtenção dos dados referentes à urbanização, além de informações anteriores e posteriores ao processo, maior tempo de conclusão das obras, comunidade organizada e participativa, sendo que seus moradores, segundo relatos, mostravam-se preocupados com a preservação e a manutenção das obras realizadas. Também o estado de conservação da área no período das visitas, se comparado com outras favelas do Lote I, finalizadas no mesmo período, estava em melhores condições.

Esse primeiro conjunto de favelas urbanizadas não obedeceu critérios claros de escolha para a sua execução, e as favelas estão longe umas das outras. A urbanização realizada nesse primeiro grupo estava voltada para as questões de saneamento ambiental.

\subsubsection{Diagnóstico da Comunidade Sete de Setembro antes da urba- nização}

A Superintendência de Habitação Popular (HABI/6-SUL; HABI/CS) apresentou um relatório, em 1992, que descreve o projeto de urbanização de favelas e exibe dados que caracterizam a área antes dos trabalhos de urbanização. A favela existe desde 1971, e apresenta uma comunidade organizada, que procura buscar melhorias juntamente com

\footnotetext{
${ }^{1}$ As Administrações Regionais foram transformadas em Subprefeituras.
} 


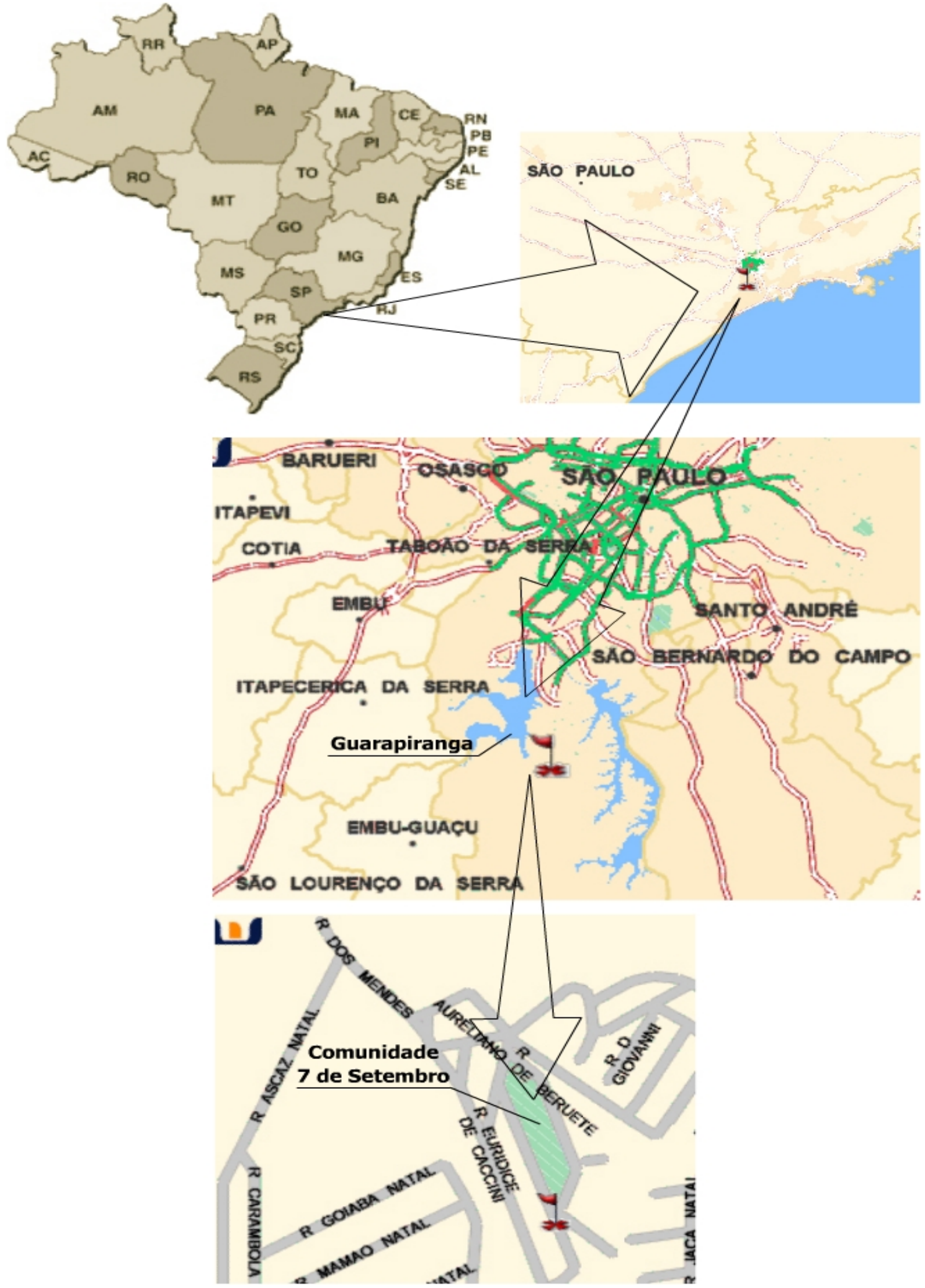

Figura 3.2: Localização da Comunidade Sete de Setembro 
outras favelas do bairro, da região da Capela do Socorro e com outros movimentos prómoradia de São Paulo.

A Comunidade foi patrocinada pelo Sindicato das Empresas de Compra, Venda e Locação e Administração de Imóveis Residenciais de São Paulo - (Secovi - SP), que desenvolveu trabalhos em conjunto com a comunidade para que viabilizasse a construção de um centro comunitário. Foi estabelecido um convênio com o SENAI e o SENAC para a realização de cursos de padeiro, serigrafia, tricô industrial etc.

A Comunidade possui um total de 110 famílias ocupando 110 unidades habitacionais. A tipologia dessas unidades é predominante em alvenaria, cerca de $90 \%$, e o restante é de madeira. As habitações estão construídas de forma regular e organizada dentro do lote.

Considerando as condições físicas do terreno, pode-se dizer que não há declividade na área; existe um córrego que corta um trecho, sendo que algumas dessas áreas estão sujeitas a erosão e enchentes.

A área ocupada pela Comunidade é de propriedade municipal de uso comum. Em 1989 foi aberto um processo(n $\left.{ }^{0} 05.009 .331 .89 * 66\right)$ junto à SEHAB para desafetação da área que após o parcelamento do solo possibilitaria a concessão de direito real de uso aos moradores. Tal processo não evoluiu até 2002 quando foi aprovado o Plano Diretor Estratégico e o Sistema de Planejamento e Gestão do Desenvolvimento Urbano do Município de São Paulo,Lei No13.430, de 13/09/02, que estabelece, no artigo 171, a Zona de Interesse Social-ZEIS ${ }^{2}$. A comunidade é classificada como ZEIS $1^{3}-027^{4}$.

\footnotetext{
${ }^{2}$ São porções do território destinadas, prioritariamente, à recuperação urbanística, à regularização fundiária e produção de Habitações de Interesse Social - HIS ou do Mercado Popular - HMP definidos nos incisos XIII e XIV do artigo 146 desta lei, incluindo a recuperação de imóveis degradados, a provisão de equipamentos sociais, espaços públicos, serviços e comércio de caráter local, compreendendo: ZEIS 1, ZEIS 2, ZEIS 3 e ZEIS 4.

${ }^{3}$ Áreas ocupadas por população de baixa renda, abrangendo favelas, loteamentos precários e empreendimentos habitacionais de interesse social ou do mercado popular, em que haja interesse público expresso por meio desta lei, ou dos planos regionais ou de lei especifica, em promover a recuperação urbanística, a regularização fundiária, a produção e manutenção de Habitações de Interesse Social - HIS, incluindo equipamentos sociais e culturais, espaços públicos, serviço e comércio de caráter local.

${ }^{4}$ Classificação do perímetro da ZEIS onde se insere a área da Comunidade Sete de Setembro.
} 
A Comunidade conta com alguns serviços públicos, como coleta de lixo e as linhas de ônibus Jd. São Bernardo e Parelheiros, que conectam o bairro ao Largo 13, no Centro de Santo Amaro. Em relação à caracterização sócio-econômica da população, no início da intervenção não se dispunha de dados exatos para elaboração de quadros demonstrativos e, portanto, foi apresentada uma caraterização geral: a população é extremamente carente, a renda familiar preponderante situa-se na faixa de 1 a 3 salários mínimos, sendo a maioria das famílias compostas por 4 a 8 pessoas.

\subsubsection{Avaliação oficial realizada após a urbanização}

A Comunidade Sete de Setembro teve sua inauguração em janeiro de 1996. Após esse período foi realizado um relatório (SEHAB-HABI, 1996) de avaliação qualitativa e quantitativa da área. Os resultados são apresentados na tabela mostrada a seguir:

Tabela 3.2: Metas cumpridas

\begin{tabular}{cc}
\hline \hline Valor do investimento & $\mathrm{R} \$ 314.168,85$ \\
\hline Valor do investimento & $\mathrm{U} \$ 323.019,59^{*}$ \\
\hline Início da obra & $08 / 10 / 94$ \\
\hline Conclusão da obra & $01 / 96$ \\
\hline Número de famílias & 132 \\
\hline Número de unidades construídas & 6 \\
\hline Rede de águas Pluviais & $245 \mathrm{~m}$ \\
\hline Rede coletora de esgotos & $885 \mathrm{~m}$ \\
\hline Rede distribuidora de água & $808 \mathrm{~m}$ \\
\hline Guias & $870,00 \mathrm{~m}$ \\
\hline Vias pavimentadas & $1.195 \mathrm{~m}^{2}$ \\
\hline Muro de arrimo & $190 \mathrm{~m}^{2}$ \\
\hline Sarjetas & $850 \mathrm{~m}$ \\
\hline Ligações domiciliares & Água $=127$, Esgoto=127 \\
\hline
\end{tabular}

(*) Dólar comercial oficial em 03 /01/ 96

utilizado para conversão $=\mathrm{R} \$ 0,9726$.

\section{Situação da Rede de Água e Esgoto}

Todas as casas possuem captação de esgoto e ligação de água da SABESP. 


\section{Remoções e Realocações}

Durante a implantação das obras, as famílias que tiveram suas casas afetadas pelo projeto ou no decorrer das obras foram removidas ou realocadas. A remoção consiste no envio do morador para outro local fora da favela, normalmente para conjuntos habitacionais previsto no Programa, ou então para outras favelas. A realocação prevê a mudança para outro local dentro da própria favela. A escolha entre realocação e remoção é feita mediante consulta aos moradores e analise das condições econômicas dessas famílias.

De acordo com o projeto, havia 5 remoções previstas devido à abertura de vias, sendo que uma delas, de uso comercial, não se enquadrava no processo de remoção nem alocação por parte da PMSP. Destas 4 remoções, uma foi evitada, na fase de execução. Entretanto, surgiram quatro novas remoções que, a princípio, constavam no projeto como remanejamentos (de acordo com o projeto, alguns moradores tiveram perda de parte da unidade habitacional, devendo a construtora repor essa perda). Portanto, foram realizadas no total 7 remoções, sendo 6 famílias enviadas para o Conjunto Habitacional Feitiço da Vila ${ }^{5}$ e 1 para a Favela Presidente Jordanópolis ${ }^{6}$. Houve 9 famílias realocadas dentro da própria favela.

\section{Unidades Habitacionais}

No projeto não havia previsão de construção de unidade habitacional, motivo pelo qual seis famílias removidas foram reassentadas no Conjunto Habitacional Feitiço da Vila, situado na Estrada de Itapecerica no Valo Velho. No entanto, posteriormente, houve necessidade da construção de 4 unidades habitacionais. Foi realizada a reconstrução de 5 unidades habitacionais.

\footnotetext{
${ }^{5}$ Distante $23 \mathrm{~km}$ da Comunidade, leva cerca de 1 hora de automóvel para chegar ao local.(Site:apontador.com.br)

${ }^{6}$ Distante a $4,3 \mathrm{Km}$ da Comunidade, leva $12 \mathrm{~min}$. de automóvel e 1 hora a pé para chegar ao local.(Site:apontador.com.br)
} 


\section{Remanejamentos}

Estava previsto o remanejamento de 28 famílias; no entanto foram realizados 53 . Não foi possível evitar nenhum remanejamento previsto. O remanejamento das habitações obedeceu o critério de reposição da área remanejada, desde que houvesse espaço, com o acabamento semelhante ao da parte demolida. Na fase de execução foi possível atender este critério, uma vez que todos os moradores tiveram reposição das perdas.

\section{Alojamentos}

Inicialmente não havia a previsão de alojamento. No entanto foram implantados 4 alojamentos e houve a utilização de 3 contêineres. O primeiro critério utilizado para a ocupação dos alojamentos foi das famílias indicadas para remoção e que aguardavam a ida para o conjunto habitacional Feitiço da Vila. O segundo critério foi o da ocupação por famílias cujas casas não ofereciam segurança devido à execução das obras. O tempo de permanência dessas famílias no alojamento foi de aproximadamente 3 a 4 meses. A localização do alojamento, o reduzido número de famílias e o curto período de permanência contribuíram para que os usuários aceitassem essa alternativa sem resistência. A casa de parentes como moradia provisória foi a solução encontrada por 4 famílias. Portanto não houve necessidade de alugar habitações provisórias.

\section{Invasões}

\section{a) De moradias}

Não houve invasão de alojamentos. No entanto uma moradia foi invadida por uma família de um funcionário da construtora responsável pela obra. A casa ocupada era destinada a uma família removida e estava em fase final de construção. Muitas dificuldades foram encontradas para retirar a família invasora da unidade habitacional e, em decorrência dessas circunstâncias, o invasor permanece no local em situação irregular, uma vez que não foi entregue o termo de ocupação. A família indicada para ocupar essa moradia teve de ser removida para outra favela em processo de urbanização do Programa Guarapiranga. 


\section{b) De Área}

Houve área invadida por 4 famílias, sendo duas de funcionários da construtora e duas de parentes de moradores da favela. A área estava livre, sem qualquer edificação pois o projeto não previa construção de unidade habitacional nesta favela. As famílias permaneceram no local com a conivência da liderança local.

\section{Permuta (xadrez)}

Quando os moradores demonstram vontade de se mudar para outro local dentro da favela, e há a possibilidade de permuta com algum outro que também o deseje, pode ocorrer um procedimento denominado xadrez. Não houve, no caso em estudo, família interessada em permutar sua moradia, portanto esse tipo de procedimento não precisou ser adotado.

\section{A população}

Em reunião realizada posteriormente ao término das obras de urbanização, a população demonstrou estar satisfeita com o projeto desenvolvido, enfatizando como aspectos positivos: a ausência de esgoto correndo a céu aberto em suas portas, ausência do mal cheiro, redução da permanência de ratos e outros insetos nocivos, possibilidade das crianças de brincar nas vielas sem riscos, melhoria das condições de saúde dos moradores em geral e em especial das crianças, mudança na estética da favela, que agora é denominada bairro.

Segundo impressões das assistentes sociais da prefeitura, foi observado que a população mostrou entusiasmo com as obras, tanto que a maioria está realizando melhorias significativas em suas moradias, através de reformas e ampliações. A população tem como expectativa a implementação de ações ainda a serem efetuadas, como a nomeação e a iluminação de vielas, a numeração das casas, a regularização fundiária etc. Na viela sobre o córrego já havia indicação, pela própria população, para receber a denominação Viela Maria Terezinha Rollemberg de Albuquerque Comisso, em homenagem à Assistente Social da SEHAB-HABI, a qual fazia parte da equipe que iniciou o trabalho social nessa favela e veio a falecer em 29/09/94. 


\section{Liderança Local}

A presidente da Comunidade Sete de Setembro possui longa experiência em trabalho comunitário. Representa de maneira atuante a população junto aos órgãos competentes, reivindicando seus interesses, gerando grande popularidade e credibilidade por parte dos moradores com relação a sua pessoa. Ela conquistou várias melhorias para a favela, tais como a construção de um centro Comunitário financiado pelo Secovi-SP - Sindicato das Empresas de Compra, Venda e Locação e Administração de Imóveis residenciais de São Paulo, e realização de Convênio com o SENAI e o SENAC.

Tal perfil contribuiu positivamente para o desenvolvimento das obras de urbanização e especialmente no trabalho social, como agente facilitador nos entendimentos entre a PMSP e os moradores. Sua participação aconteceu em todas as fases do trabalho, desde a indicação da favela até o término das obras. No entanto, em alguns momentos defendeu o interesse particular de alguns moradores em detrimento do coletivo, em situações que se exemplificam pela permissão de áreas livres e invasão de unidade habitacional por pessoas não oriundas da favela, fora da demanda do programa. 


\section{Capítulo 4}

\section{Método de estudo}

\subsection{Conceituação de APO}

Segundo ORNSTEIN (1992), o método Avaliação Pós-Ocupação (APO) pretende, a partir da avaliação de fatores técnicos, funcionais, econômicos, estéticos e comportamentais diagnosticar aspectos positivos e negativos do ambiente em uso, tendo em vista tanto a opinião dos técnicos, projetistas e clientes, como também dos usuários, lembrando que:

- Em primeiro lugar, é necessário minimizar, ou até mesmo corrigir, problemas detectados no próprio ambiente construído submetendo-o a avaliações, através da utilização de programas de manutenção e de conscientização do público usuário, das necessidades de alterações comportamentais, tendo em vista o bem-estar e a conservação do patrimônio público ou privado;

- Em segundo lugar, é igualmente preciso utilizar resultados destas avaliações sistemáticas (estudos de casos) para realimentar o ciclo do processo de produção e uso de ambientes semelhantes, buscando otimizar o desenvolvimento de projetos futuros. Em outras palavras, a APO pode ser entendida como um método interativo que detecta patologias e determina terapias no decorrer do processo de produção e uso em ambientes construídos, através da participação intensa de todos os agentes envolvidos na tomada de decisões.

Esta metodologia pode ser visualizada no fluxograma da Figura 4.1. 


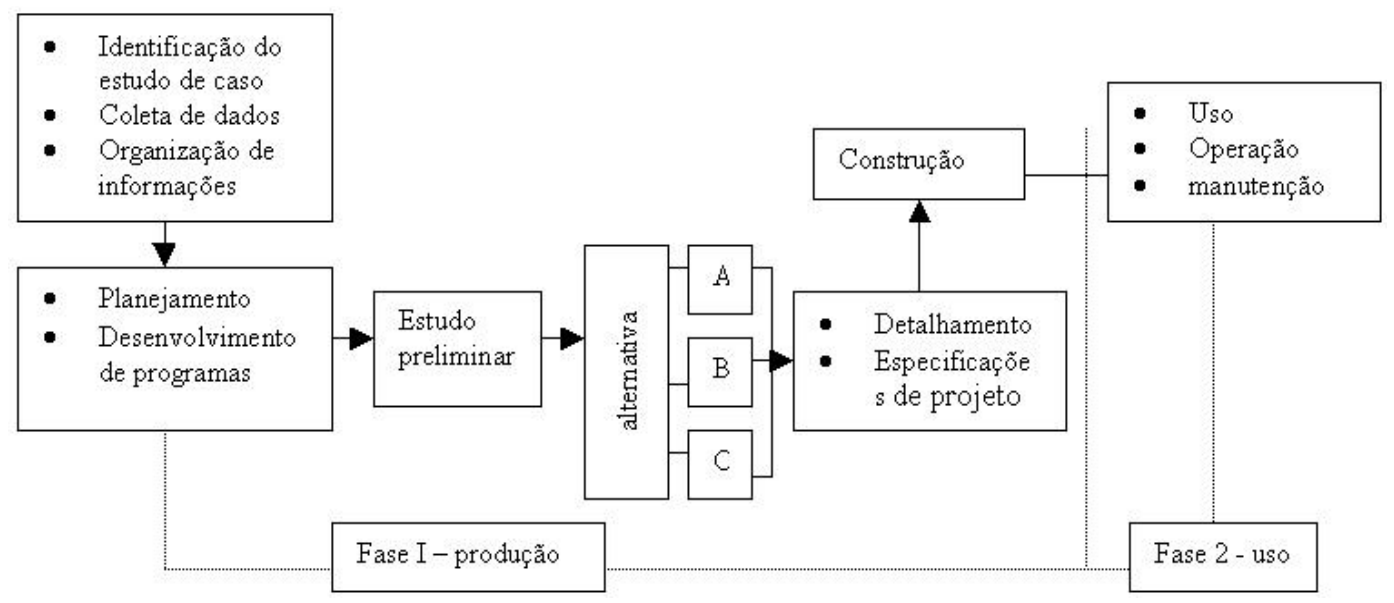

Figura 4.1: APO - Ciclo de realimentação do processo de produção e uso. (ORNSTEIN, 1992).

Existem basicamente três tipos de níveis de serviços de avaliação que se diferenciam a partir da profundidade com que a pesquisa é realizada, bem como dos recursos disponíveis. Sendo assim, ORNSTEIN(1992) apresenta os três níveis propostos:

APO Indicativa ou de curto prazo: proporciona, através de rápidas visitas exploratórias ao ambiente em questão e entrevistas com usuários-chave, indicação dos principais aspectos positivos e negativos do objeto de estudo.

APO Investigativa ou de médio prazo: trata-se do nível anterior acrescido da explicitação de critérios referenciais de desempenho.

APO Diagnóstico ou de longo prazo: define detalhadamente critérios de desempenho, utiliza técnicas sofisticadas de medidas correlacionando as mudanças físicas com as respostas dos usuários, tendo-se em mente a estrutura organizacional da entidade. Para tanto, exige recursos bem maiores do que os níveis anteriores.

Em nosso estudo de caso iremos adotar procedimentos do primeiro tipo, ou seja, a APO Indicativa. 


\subsection{Avaliação Pós-Ocupação (APO) - Um breve histórico}

Os estudos desenvolvidos no campo das Ciências Sociais e do Comportamento cuja interdisciplinaridade é representada por Moore apud Ornstein (1990) podem ser didaticamente divididos nas seguintes sub-disciplinas: geografia social, sociologia ambiental, psicologia ambiental, ergonomia, desenho de interiores, arquitetura, paisagem urbana e paisagismo, planejamento urbano, gerenciamento de recursos naturais, ecologia e antropologia urbana. Tais estudos, incluindo sua abordagem interdisciplinar, tiveram como países precursores os Estados Unidos (enfoque comportamental), a Alemanha (enfoque ecológico) e o Japão (enfoque filosófico-cultural). Dentre estes, os Estados Unidos são o país que mais se destaca na produção de trabalhos. Até $1985,48,2 \%$ da produção de pesquisas relacionadas à área das relações Ambiente-Comportamento no mundo eram oriundas dos EUA e Canadá (ORNSTEIN,1993) .

Segundo ORNSTEIN (1993), a evolução histórica de tais estudos realizados nos EUA pode ser classificada em três fases de pesquisa: exploratória ${ }^{1}$, sistemática $^{2}$ e interdisciplinar $^{3}$. Nesta última surgem os primeiros periódicos interdisciplinares, o "Behavior and Environmental Design"(1965) e o Journal of Social Issues (1966); em 1968 surge a primeira associação: EDRA - Environmental Design Research Assosiation e, em 1969, o periódico Environment and Behavior.

Neste período, pode ser verificado um grande fortalecimento na área de estudos do ambiente e comportamento e, conseqüentemente, nas pesquisas envolvendo Avaliação PósOcupação. Esse reflexo pode ser observado se comparado ao elevado número de programas de mestrado e doutorado em inúmeras universidades e institutos Americanos ${ }^{4}$. BECHTEL(1987) aponta que no final da década de 80 mais de 1500 APOs foram publicadas sobre habitação.

No Brasil, o desenvolvimento de pesquisas na área de ambiente e comportamento, mais

\footnotetext{
${ }^{1}$ Iniciada no final da década de 40 por pesquisadores geógrafos e psicólogos, tendo avaliações físicas com participação de usuários.

${ }^{2}$ Surge em meados de 50, quando aparece a visão ambientalista.

${ }^{3}$ Iniciada na década de 60 , quando surgem diversas contribuições conjuntas de especialistas de distintas sub-disciplinas.

${ }^{4}$ Nova York, Califórnia, Irvine, Georgia, Arizona, dentre outros.
} 
especificamente APOs, tiveram como marco inicial o ano de 1984 com a primeira disciplina oferecida na pós-graduação da Faculdade de Arquitetura da Universidade de São Paulo, que contou com a colaboração de pesquisador americano ${ }^{5}$. A partir deste ponto foram realizadas várias modificações adequando o método APO proposto por Preiser à realidade brasileira. Na fase inicial, nossos pesquisadores priorizaram o enfoque às características técnicas e funcionais dos edifícios; no entanto, atualmente os aspectos comportamentais (behaviorism) passaram a ser alvo de atenção. Na produção científico-acadêmica nacional merecem destaque a Faculdade de Arquitetura e Urbanismo e a Escola Politécnica de São Paulo da Universidade de São Paulo, e as Universidades Federais do Rio Grande do Sul, de Minas Gerais e de Goiânia.

\subsubsection{A produção Internacional e sua relação com o Brasil}

Na produção norte americana, merecem destaque alguns autores considerados marco dos estudos sobre ambiente e comportamento e utilização da APO:

NEWMAN $(1973)^{6}$ fez estudos comparativos de vários conjuntos habitacionais e correlacionou a forma arquitetônica e a densidade de ocupação como um dos fatores que influenciam na ocorrência de crimes. CARR (1992) estuda várias áreas públicas livres destinadas ao laser procurando correlacionar sua utilização e manutenção a fatores culturais, à necessidade do usuário etc. LYNCH (1960) estuda três cidades norte-americanas procurando analisar sua ocupação e dá ênfase à dimensão urbana das cidades. HALL (1989) analisa como os aspectos culturais, comportamentais e humanos são importantes e influenciam na determinação do ambiente arquitetônico e urbano. SOMMER (1973) trabalha dois aspectos do comportamento humano: "o primeiro refere-se à zona emocionalmente carregada em torno de cada pessoa, às vezes descrita como uma bolha de sabão ou aura, e que ajuda a regular o espaçamento entre os indivíduos. O segundo refere-se a processos através

\footnotetext{
${ }^{5}$ Pesquisadores: Dr. Wolfgang F. E. Preiser, da School of Arquitecture \& Planning, University of New México, Albuquerque.

${ }^{6}$ Publicou o livro "Defensible Space: Crime Prevention Through Urban Design", em que analisa como o ambiente projetado pode influenciar o comportamento humano.
} 
dos quais as pessoas marcam e personalizam os espaços que habitam"(SOMMER, 1973). RAPOPORT (1969) trabalha o conceito de habitação, analisa como a forma de habitação está intimamente ligada a fatores de ordem cultural e de comportamento das pessoas e enfatiza a necessidade dos projetistas de conhecerem este universo para propor soluções mais próximas à realidade. SHIRVANI (1990) estuda a arquitetura e vários aspectos da utilização de espaços públicos (praças, edifícios), por meio da APO, situados em várias cidades americanas. PREISER (1998) concentra sua pesquisa no levantamento histórico, na conceituação da APO e sua aplicação através de três estudos de casos em edifício de escritório, de escola primária e secundária. MARCUS (1995) faz um estudo sobre o verdadeiro significado que a habitação pode assumir para cada indivíduo, bem como aspectos relacionados a sua utilização e função. Outro trabalho desenvolvido pela autora em 1990, intitulado "People Places: Design Guidelines for Urban Open Space", traz importantes contribuições no desenvolvimento de trabalhos que envolvem a aplicação de APO em espaços abertos. Neste são apresentados sete estudos de casos realizados em: praças públicas, parques de vizinhança, miniparques, espaços públicos como extensão da habitação de idosos, espaços livres vinculados a berçários e espaços livres vinculados a hospitais.

A produção científica americana tem seu maior peso no desenvolvimento de trabalhos voltados aos fundamentos teóricos metodológicos envolvendo APO, bem como na produção de estudos de casos envolvendo edifícios públicos, escritórios, análise do comportamento humano e da sociedade, conjuntos habitacionais, forma da cidade, dentre outros, diferentemente do enfoque mais tecnológico e funcional das habitações adotado na década de 80 no Brasil que agora passa a desenvolver estudos que consideram os aspectos comportamentais.

Neste trabalho foi fundamental a leitura de tais autores, para conhecer tanto a contextualização teórica como os estudos de casos realizados nesta área de PÓS-USO. No entanto, as características sociais, culturais e econômicas refletidas pelos problemas do ambiente urbano existente nos Estados Unidos diferem bastante daquelas encontradas no Brasil, portanto a literatura nacional foi mais utilizada como referência no desenvolvimento des- 
ta parte da pesquisa.

\subsection{Fundamentação teórica dos métodos utilizados}

"O estudo de caso não terá uma técnica específica, mas uma análise holística, a mais completa possível, que considera a unidade social estudada como um todo, seja um indivíduo, uma família, uma instituição ou uma comunidade, com o objetivo de compreendê-los em seus próprios termos"GOLDENBERG (1997).

Objetivando alcançar a magnitude dos aspectos que envolvem o estudo de caso proposto, foi adotada a abordagem qualitativa na busca de informações junto à população e às pessoas envolvidas na urbanização da área.

Os procedimentos metodológicos da APO utilizados foram: levantamento documental, aplicação de questionários, levantamento de equipamentos de infra-estrutura urbana e de serviços que atendem a Comunidade, levantamento do estado de conservação e utilização das áreas públicas registradas no mapeamento comportamental e entrevista semiestruturadas com grupos focais. Em tal método é necessário considerar alguns cuidados que serão detalhados a seguir:

\subsubsection{Observação}

Segundo GOLDENBERG (1997), a observação direta apresenta a vantagem metodológica de permitir um acompanhamento mais prolongado e minucioso das situações. Essa técnica, complementada com entrevistas em profundidade, permite revelar o significado que diversas situações têm para os indivíduos, possibilitando resultados mais amplos do que os que aparecem em questionários padronizados.

Segundo LÜDKE; ANDRÉ (1986) para que a observação seja instrumento válido e fidedigno de investigação científica, é necessário o controle e a sistematização, devendo assim se realizar um planejamento cuidadoso do trabalho e uma preparação rigorosa do observador. 
O pesquisador deverá determinar com antecedência "O que"e "Como"observar. Neste estudo, realizaram-se a observação e o registro das atividades dos moradores nas áreas públicas da Comunidade.

Tais registros são chamados de mapeamento comportamental, ou seja, 'behavior maps' técnica desenvolvida por Ittleson, Proshansky, e Rivlin (1970), que usa um roteiro para registrar as categorias de comportamento e o local onde este processo ocorra"ZIMRING (1987).

O pesquisador deve estabelecer anteriormente qual será o grau de sua participação. Em nosso estudo, adotamos o método que LÜDKE; ANDRÉ (1986) nomeiam "observador como participante", e neste caso a identidade do pesquisador e seus objetivos de trabalhos são relatados. Nesta posição o pesquisador pode ter acesso a uma gama variada de informações, muitas vezes confidenciais. Neste caso ele deverá respeitar o grupo e só colocar em público as informações autorizadas por eles. No estudo realizado, os moradores permitiram publicar as informações. No entanto, suas identidades foram preservadas.

O tempo e o período em que o observador deve permanecer em campo é um outro fator que deve ser estimado. "A decisão sobre a extensão do período de observação deve depender, acima de tudo, do tipo de problema que está sendo estudado e do propósito do estudo. Um aspecto que deve ser levado em conta nessa decisão é que, quanto mais curto o período de observação, maior a probabilidade de conclusões apressadas, o que compromete a validade do estudo. Por outro lado, um longo período de permanência em campo por si só não garante validade. É preciso levar em conta outros fatores, como a habilidade e experiência do observador, a possibilidade de acesso aos dados, a receptividade do trabalho pelo grupo, a finalidade dos resultados, etc"LÜDKE; ANDRÉ (1986).

O tempo de observação e a permanência da pesquisadora no campo foram baseados na consideração dos fatores apontados acima. Foi realizado um levantamento nas publicações nacionais com objetivo de conhecer os trabalhos realizados no campo da engenharia e da arquitetura que utilizaram a observação como método para busca de informações. Tal levantamento permitiu conhecer o tempo médio de permanência em campo, bem como os 
aspectos que devem ser considerados para definição deste tempo ${ }^{7}$. No capítulo referente a pesquisa de campo, são apresentados os aspectos considerados definidores para o estudo de caso do presente trabalho.

Quanto ao conteúdo das informações LÜDKE; ANDRÉ (1986) apresentam uma série de recomendações a serem consideradas em trabalhos cuja observação é baseada em abordagens qualitativas. Segundo os autores, o conteúdo das observações pode ser dividido em duas partes: uma mais descritiva e outra mais reflexiva. Na parte descritiva são abordados os aspectos que ocorrem efetivamente no campo: os registros são compostos basicamente pela descrição dos sujeitos, reconstituição de diálogos, descrição dos locais, de eventos especiais, das atividades e comportamentos do observador. Quanto à parte reflexiva, nela incluem-se as observações pessoais do pesquisador feitas durante as coletas de dados, podendo ser: suas especulações, sentimentos, problemas, idéias, impressões, dúvidas, surpresas dentre outros. Tais reflexões podem ser analíticas, metodológicas, dilemas éticos, mudança na perspectiva do observador e/ou esclarecimentos necessários.

O registro das observações podem ser de diversos tipos. No trabalho proposto, procuramos considerar os registros presentes em anotações, fotografias e mapas comportamentais. "Sob o ponto de vista essencialmente prático, é interessante que, ao iniciar cada registro, o observador indique o dia, a hora, o local da observação e o período de duração"LÜDKE; ANDRÉ (1986).

O trabalho de campo procurou atender as sugestões apontadas neste item para que as observações realizadas pudessem, de fato, configurar uma pesquisa científica.

\subsubsection{Entrevistas}

Todas as APOs incluem algum tipo de entrevista com usuários, projetistas, transeuntes, financiadores, gerenciadores de espaços, dentre outros.

"Uma entrevista bem-feita permite tratar assuntos de natureza estritamente pessoal e íntima, assim como temas de natureza complexa e de escolhas nitidamente individuais. Pode

\footnotetext{
${ }^{7}$ Os trabalhos de LIMA; PELEGRINO (1993); MEDVEDOVSKI (1993); SANTOS et al. (1998); ANDRADE et al (2000); TABLAS et al. (2000) e LAY ( 2000) foram exaustivamente consultados para a elaboração de como realizar observações comportamentais em campo.
} 
permitir o aprofundamento de pontos levantados por outras técnicas de coleta de alcance mais superficial, como o questionário. E pode também, o que a torna particularmente útil, atingir informantes que não poderiam ser atingidos por outros meios de investigação, como é o caso de pessoas com pouca instrução formal para as quais a aplicação de um questionário escrito seria inviável"LÜDKE; MENGA(1986).

Segundo LÜDKE; MENGA(1986), em relação a entrevistas, não existem receitas infalíveis a serem seguidas; no entanto, alguns cuidados, aliados à atuação inventiva, honesta e atenta do condutor, poderão levar a uma boa entrevista. Procurando responder a estas questões, durante a pesquisa com grupos focais, foi incluída a participação de uma jornalista especialista na área. Esta profissional foi consultada durante a elaboração dos roteiros e participou das entrevistas, bem como do registro e da análise dos dados.

A entrevista constitui-se como um instrumento largamente utilizado na pesquisa científica, já que permite captar imediatamente a informação desejada, praticamente com qualquer tipo de informante. No entanto, um aspecto fundamental a ser considerado é a importância que a interação assume na utilização deste instrumento.

Neste sentido LÜDKE; ANDRÉ (1986) e ZIMRING (1987) classificam as entrevistas em três tipos básicos. Tem-se a entrevista não estruturada, na qual não há um roteiro a ser seguido, o que dá ao entrevistador e ao entrevistado total liberdade para o seu encaminhamento. A entrevista estruturada segue um roteiro pré-estabelecido, sendo bastante parecida com um questionário, nela o entrevistado e o entrevistador não têm liberdade para sair do roteiro estabelecido, devendo seus dados receber tratamento estatístico. Entre esses dois tipos, existe a entrevista semi-estruturada, que se desenvolve a partir de um esquema básico, porém não aplicado rigidamente, permitindo que o entrevistador faça as necessárias adaptações.

Dentre estes tipos de entrevista, adotou-se no presente trabalho a entrevista semi-estruturada para a coleta de dados junto aos moradores. Não havendo imposição de uma ordem rígida de questões, neste tipo de entrevista, o entrevistado discorre sobre um tema que lhe é proposto a partir das informações que ele detém e que, na verdade, configuram o interesse da entrevista. 
Segundo ZIMRING ( 1987), entrevistas realizadas em pequenos grupos (de 02 a 10 pessoas) alcançam sucesso na medida em que um participante estimula o outro.

Em nosso estudo, procuramos estabelecer o tamanho do grupo em 4 pessoas, sendo a faixa etária para a realização das entrevistas semi-estruturadas definida de acordo com ZIEGLER; ANDREWS (1987). Os autores autor apontam a idade ideal para realização de determinadas técnicas de coleta de dados. A discriminação de tais faixas etárias é baseada em características e especificidades do comportamento humano. Acima de 13 anos, segundo o autor, podem ser adotados os mesmos procedimentos que os utilizados na coleta de adultos. Dentre as várias técnicas apresentadas pelo autor de acordo com as faixas etárias, destacamos as utilizadas neste trabalho: as entrevistas semi-estruturadas, a observação comportamental. O registro das informações coletadas foi feito através de gravação e anotações durante as entrevistas.

\subsubsection{Análise documental e dos dados coletados}

Segundo LÜDKE; ANDRÉ (1986), a análise de dados qualitativos é um processo criativo que exige grande rigor intelectual e muita dedicação. Não existe uma forma melhor ou mais correta. O que existe é sistematização e coerência do esquema escolhido com o que pretende o estudo. Como não é possível uma análise estatística de dados qualitativos, não existindo nenhum teste estatístico que permita avaliar se uma observação é significativa ou não, os pesquisadores devem basear-se na sua própria inteligência, experiência e julgamento.

A análise dos relatos, das fotos, anotações, enfim, dos dados coletados, era feita parcialmente, no decorrer da pesquisa de campo. Com a obtenção de novos e diferentes dados que se somavam às informações já obtidas, novas análises eram realizadas. Em alguns momentos, foram feitas comparações entre dados mais antigos e mais atuais. Desta maneira, o trabalho foi ganhando maior sentido, e o conhecimento da realidade dos moradores da área pôde ser aprofundado. 


\section{Capítulo 5}

\section{Estudo de caso}

\subsection{A escolha da área para os estudos}

Os procedimentos utilizados para a escolha da área foram basicamente: levantamento documental, entrevistas, visitas em áreas urbanizadas e em processo de urbanização.

\subsubsection{O levantamento documental}

Procurou-se levantar materiais referentes ao Programa Guarapiranga em sua totalidade. Tais documentos foram obtidos na Secretaria de Habitação da Prefeitura de São Paulo SEHAB-II e na Unidade de Gerenciamento do Programa - UGP.

\subsubsection{As entrevistas}

Da UGP (Unidade de Gerenciamento do Programa), da Diagonal (Empresa que presta consultoria a Prefeitura de São Paulo), da HABI (Superintendência de Habitação Popular da Prefeitura de São Paulo), da JNS-Hagaplan (Consórcio de engenharia que presta consultoria e gerência projetos no Programa) foram entrevistados tecnólogos, engenheiros, arquitetos, assintentes sociais, e além desses foram entrevistados os coordenadores do Programa no Estado e na Prefeitura de São Paulo.

Através das entrevistas a pesquisadora procurou entender o Programa sob o ponto de vis- 
ta desses agentes. Durante as entrevistas, as questões levantadas eram relacionadas aos desafios encontrados pelos entrevistados na implementação do Programa, bem como na execução dos projetos específicos de urbanização.

Tais entrevistas foram positivas, pois além do arquivo documental, pôde-se analisar os relatos, enriquecendo o entendimento do Programa, pois essas pessoas, além de fornecer informações sobre o Programa Guarapiranga como um todo, também apresentavam as especificidades ou diferenças dentre os vários projetos de urbanização, além das características das várias favelas que já haviam sido urbanizadas.

Tanto o corpo técnico entrevistado como as assistentes sociais enfatizaram que a Comunidade Sete de Setembro se destacava dentre as demais favelas pela organização social e atuação de seus moradores durante a execução das obras. Mediante estes fatos os técnicos acreditavam que a área seria preservada após a urbanização, devido à conscientização e atuação da Comunidade.

Essa característica foi considerada essencial na escolha da área, pois questões relacionadas ao Pós-Uso, ou seja, à conservação das obras, estão intrinsecamente relacionadas ao sucesso do Programa.

\subsubsection{As visitas técnicas}

Foram realizadas visitas técnicas em diferentes áreas urbanizadas, com intuito de verificar o estado de conservação e utilização das áreas externas às habitações. Algumas áreas cujos projetos estavam em andamento também foram visitadas, com o principal objetivo de verificar como eram executados os trabalhos técnicos e de assistência social. É fundamental compreender como é feita a implementação dessa urbanização, que se diferencia dos projetos "tradicionais", pois a população não é retirada da área, a não ser em situações de risco ou insalubridade elevada.

Foram visitadas as favelas Jardim Iporanga, Jardim Esmeralda, Jardim Alpino, Jardim Floresta, Favela Parque Amélia, Jardim Copacabana e Comunidade Sete de Setembro, todas pertencentes ao Programa Guarapiranga. Durante tais visitas procurava-se conversar 
informalmente com as lideranças locais, buscando informações sobre a área visitada, registrando dados que poderiam ser considerados na escolha da área objeto de estudo desse trabalho. Tais visitas foram realizadas no primeiro semestre de 1998, de acordo com o cronograma de obras e disponibilidade da equipe de assistentes sociais da Habi.

Com o cruzamento das informações coletadas nas entrevistas, nas observações e registros realizados durante as visitas técnicas nas diversas áreas, bem como dos materiais bibliográficos coletados nessa primeira fase, foi possível escolher a área objeto de estudo desse trabalho.

\subsection{O questionário Piloto}

Inicialmente, pensamos em utilizar uma abordagem quantitativa na coleta de dados junto aos moradores, e daí surgiu o questionário piloto. Posteriormente, abandonamos a idéia inicial, porque através do método qualitativo poderíamos obter resultados mais eficientes. No entanto, as informações obtidas no questionário piloto também puderam nos subsidiar na composição dos dados referentes à caracterização do universo que estamos tratando. Uma cópia do questionário encontra-se no anexo 4.

A formulação do questionário teve como principal objetivo coletar informações, considerando como eixo principal a opinião da população envolvida, ou seja, o ponto de vista do morador da área em que as obras foram realizadas. Ele foi dividido em três principais momentos, nomeados por Blocos I, II e III.

O primeiro bloco, constituído por 13 questões, teve como objetivo a caracterização da família entrevistada, ou seja, delinear o perfil da população. No segundo bloco, constituído por 5 questões, procurou-se fazer um levantamento da participação da população enquanto organização comunitária. No terceiro bloco, que é constituído basicamente de 17 questões, procurou-se obter informações sobre o nível de satisfação dos moradores após a urbanização.

Para a aplicação do questionário, houve um contato com a liderança local, visando informála e também coletar dados que pudessem ser úteis. 
O questionário foi aplicado numa quarta-feira, 24 de junho de 1.999, a partir das 13:00h. Foram aplicados um total de 08 questionários, sendo que 04 foram preenchidos pelos próprios moradores com o auxílio posterior da pesquisadora para o esclarecimento de dúvidas. Os demais foram aplicados diretamente pela pesquisadora, pois os entrevistados não tinham grau de instrução que permitisse o seu preenchimento. Este processo levou em média 40 minutos.

Numa pesquisa quantitativa, a função do questionário piloto é testar se serão atendidas as expectativas do pesquisador na busca das informações desejadas. Assim, a quantidade de questionários aplicados nessa fase de teste não é importante e não segue o rigor estatístico necessário numa pesquisa quantitativa definitiva, por isso as informações coletadas não podem ser extrapoladas. Alguns valores apresentados em porcentagem são referentes ao percentual do total de 08 famílias, não representando o conjunto de moradores da área.

Nesse estudo, em que se modificou o tipo de abordagem no decorrer da pesquisa, foram analisadas todas as informações, essas servirão como indícios de alguns fatos que posteriormente poderão ser confirmados, ou não.

Analisando as questões do Bloco I: - Verificamos que uma parcela dos moradores da comunidade mudou-se para São Paulo a partir das décadas de 50 e 60, confirmando o tipo de migração descrito no texto introdutório desta pesquisa;

- A maioria dos moradores adquiriu a habitação através de compra, e não da ocupação direta;

- A grande maioria dos entrevistados é formada por proprietários da habitação que moravam na área quando foram realizadas as obras de urbanização, portanto, vivenciaram as fases pré e pós-urbanização;

- Observou-se um grande número de pessoas desempregadas;

- O baixo nível de escolaridade é verificado, tanto nos entrevistados quanto nas famílias, sendo que grande parte destes não possuem o primeiro grau completo;

- Quanto à composição familiar, podemos dizer que o número de pessoas é considerado 
elevado, com famílias compostas de 5 a 7 membros.

Pudemos verificar, nas questões do Bloco II, o envolvimento de parte da população em assuntos da vida comunitária, pois pensam ser importante a atuação da Associação Comunitária para conseguir melhorias no bairro. Uma dessas lideranças locais está focada em Sueli, reconhecida como tal pela maioria desses moradores.

Quanto aos questionários respondidos no Bloco III, podemos comentar que:

- Os respondentes não sentem que houve redução na quantidade de assaltos após a urbanização, ou seja, talvez não tenha havido transformação relacionada à segurança;

- Grande parte dos respondentes adquiriu eletrodomésticos, ou seja, podemos pressupor que houve uma sensível melhora no poder aquisitivo de tais pessoas;

- Os aspectos que as famílias apontam como positivos são a pavimentação, o aumento nos pontos de comércio, a obtenção de endereço e transformação da área de favela a bairro. Os aspectos negativos surgidos foram: rede de esgoto com problemas, quantidade de escolas, falta de iluminação pública em algumas vielas e travessas, pinturas "esquisitas"(cores muito fortes: crítica ao Projeto Reboco ${ }^{1}$ ), redução dos espaços existentes entre as casas, inexistência de ponto destinado à coleta de lixo, inexistência de casa lotérica e de agência de correio, falta de telefones públicos e de segurança;

- Em relação à existência das vielas, uma parte das pessoas achou que ficaram boas, pois retiraram o esgoto a céu aberto que havia antes. No entanto, parte dos respondentes considera tais locais sem segurança e desorganizados;

- Os moradores fizeram alguma reforma, ampliação ou acabamento interno ou externo na residência;

- Os respondentes não vêem sentido nas áreas verdes no interior da favela;

Durante visitas, pôde-se observar que os locais que foram destinados à área verde encontramse parcialmente destruídos ou sendo utilizados para outros fins. Quando colocadas as

\footnotetext{
${ }^{1}$ Projeto Reboco é a aplicação de reboco colorido na frente e na lateral das casas com vista para as vias principais.
} 
questões sobre tal tema, o entrevistado não vê sentido nelas, portanto, talvez seria melhor optar por sua retirada ou reformulá-las.

- Em relação ao contato com moradores de outras comunidades vizinhas, a maioria respondeu que não tem relação com as demais; quanto às questões relacionadas ao cuidado e utilização de áreas verdes, metade respondeu que não reconhece sua existência, a outra considera-se insatisfeita. Grande parte dos entrevistados sente-se satisfeitas em relação à convivência social entre adultos e jovens, outros sentem-se insatisfeitos porque as crianças não podem brincar com segurança na rua; os entrevistados estão satisfeitos com o acesso do jovens à escola. A quase metade deles está insatisfeita com os locais destinados para realização de atividades esportivas; metade dos entrevistados está insatisfeita com a iluminação nas vielas, no entanto considera-se satisfeitos com a iluminação nas vias de circulação; o acesso aos meios de transporte foi considerado em grande parte como satisfatório ou muito satisfatório; em relação às instalações públicas, as pessoas sentem-se insatisfeitas; em relação à conservação das áreas verdes, calçadas, e o serviço de limpeza pública, mais da metade está muito satisfeita.

- Em relação à questão de manutenção, 1/3 das respostas apontam que os respondentes não se sentem responsáveis pela manutenção das modificações executadas na comunidade; $1 / 3$ se sente responsável, e 1/3 respondeu que não sabe;

- Constata-se que metade dos entrevistados não venderia sua casa, ou seja, a maioria das pessoas consolidou a favela como moradia definitiva e não como local de passagem, e ainda, muitos deles não têm interesse de alugar suas habitações;

- A grande maioria considerara bom o aspecto visual da área após a urbanização, e outra parte acha ótimo. Sob o aspecto visual, a aceitação foi quase unânime.

- Em relação ao Projeto Reboco, não podemos considerar nenhuma tendência, pois existe um equilíbrio entre a porcentagem que o considerou positivo e aquela que o desaprovou; No questionário piloto, o que se observa é que as obras de urbanização contribuíram e muito na melhoria de vida dos moradores e da comunidade, pois estas mudanças trou- 
xeram o reconhecimento e a consolidação do seu espaço de trabalhador/morador, com residência estabelecida em rua com nome, número e cep, enfim, um endereço, ou seja, um local onde ele possa ser encontrado.

\subsection{Caracterização da Comunidade Sete de Setembro}

Para a caracterização da Comunidade Sete de Setembro foi realizado um levantamento documental que abrangeu várias instituições.

Na SEHAB II foi realizado um segundo levantamento documental, encontrando-se informações variadas, totalizando 30 tópicos classificados por títulos - Anexo 1. Na Construtora BETER, responsável pela execução das obras na Sete de Setembro, foi encontrado um arquivo de 32 fotos referentes à fase anterior à urbanização, durante a realização das obras e após sua conclusão.

No Consórcio JNS-HagaPlan, uma gerenciadora de Projetos que deu suporte ao Programa Guarapiranga, foram encontrados alguns relatórios e também um arquivo de mais de 100 fotos referentes à obra, em todas as suas fases. A lista de materiais desses dois escritórios encontram-se no Anexo 2. Na Unidade de Gerenciamento do Programa - UGP, foram encontrados diversos materiais como mapas, plantas do Projeto específico e outros que foram numerados e descritos no Anexo 3.

Esta análise possibilitou a elaboração do capítulo 3, que constitui a descrição formal do Programa Guarapiranga e da Favela Comunidade 7 de Setembro.

Alguns contatos estabelecidos na fase da coleta de dados foram retomados para obter o aprofundamento das informações sobre a Comunidade Sete de Setembro. Tais contatos deram-se basicamente com a Diagonal, Habi, a Beter e com a JNS-HagaPlan.

Neste momento procuramos estabelecer o contato direto com pessoas que trabalharam ou sabiam de informações sobre o período de urbanização da Sete de Setembro, quais foram as principais dificuldades e soluções encontradas durante os trabalhos na área, e se havia alguma especificidade que a distinguia dos outros projetos de urbanização. Algumas in- 
formações adicionais àquelas coletadas na primeira fase são descritas a seguir:

O projeto de Urbanização foi criado na Gestão da Prefeita Luíza Erundina; no entanto, não foi possível a sua conclusão, sendo assim, sofreu posteriormente alguns ajustes para ser implementado na gestão do Prefeito Paulo Maluf.

A Sete de Setembro foi a primeira favela inaugurada do Lote I a receber o projeto de urbanização incluindo o Projeto Reboco.

Para a implantação do Projeto Reboco, foi feita uma reunião com a comunidade para sua apresentação e aceitação. Os moradores participaram da escolha das cores, no entanto, após algum tempo, eles acabaram trocando as cores consideradas muito fortes por outras mais claras. Tal projeto foi implantado com o intuito de oferecer um benefício a mais para os moradores, mas não foi bem aceito.

Normalmente, várias alterações são percebidas desde o projeto proposto inicialmente até o executado, pois ocorrem vários imprevistos durante a implantação da obra, por exemplo: a SABESP exige determinado padrão de inclinação na área, além de ruas com largura suficiente para passagem de seus caminhões para manutenção das redes instaladas; as máquinas retro utilizadas para a canalização dos córregos são pesadas e abalam as estruturas das casas, construídas sem fundação; verifica-se uma série de obras resultantes do próprio processo da obra principal, sem que se possa presumir ou avaliar, dentre outros casos.

Sobre o estado das obras que compuseram o Lote I, resolvemos colocar uma fala colhida de um dos técnicos entrevistados durante a pesquisa, por retratar o exemplo do tipo de pensamento que vários deles tinham na primeira fase e que nos levou a direcionar o estudo sobre tal área: "algumas áreas se mantiveram na situação de urbanização bem interessante, que é o caso da Sete de Setembro. A aceitação das mudanças acarretou o investimento do morador na própria habitação; muitos reformaram, construíram o segundo pavimento. Até o nome da favela foi modificado, era favela Sete de Setembro e agora é Comunidade Sete de Setembro. Diferentemente da favela Presidente Jordanópolis, que é uma favela do Lote I também, e lá estão depredados os painéis, e a pintura as áreas verdes e os bancos foram retirados da área." 
Alguns fatores que ocorreram durante a execução das obras do Guarapiranga e que foram considerados negativos pela equipe de engenharia podem ser citados:

Por exemplo, uma obra prevista para ser finalizada em 10 meses e que acabava durando 2 anos, gerava uma interferência na vida e no cotidiano da Comunidade, ocorrendo a utilização do alojamento provisório por um tempo maior do que o previsto. Houve atraso na entrega das obras da Sete de Setembro.

Em geral, no período de chuvas, quase não se tem obras nas áreas, porque sempre que se escava uma vala, ela é novamente coberta. A pavimentação não é feita na época do verão, pois não é possível secar. Nesse período, então, prioriza-se a construção de muro de arrimo e demais obras secas. Percebe-se, assim, que há vários limitantes climáticos que se somam aos fatores de ordem financeira para o atraso das obras. Na Sete de Setembro, tais fatores também ocorreram.

Na Sete de Setembro não foram verificados problemas ligados ao tráfico de drogas, recorrentes em outras áreas. "Houve áreas em que éramos avisados de que haveria um tiroteio, então tínhamos que desocupá-las. Quando terminava o incidente, voltávamos para terminar os trabalhos. Tais grupos impunham horário para o nosso trabalho, ou seja, tínhamos que parar as obras, muitas vezes mais cedo que o previsto. Houve áreas em que, a partir das $15 \mathrm{~h} 00$, não se podia mais trabalhar. Houve vários casos de roubos de equipamentos técnicos e automóveis".

"Outro fator que dificultava o andamento das obras no Guarapiranga é quando não há liderança clara e genuína na área, pois as questões ficam pontuais e o morador fica preocupado se o muro dele vai cair, ou sua casa vai desabar (...) então as dificuldades aparecem em todos os sentidos, no social e no físico. No caso da Sete de Setembro isso não ocorreu pois a área tinha uma liderança consolidada."

A equipe de assistentes sociais apontou que não é realizado nenhum tipo de trabalho de educação ambiental em paralelo à execução das obras, e também não há previsão a posteriori. Leia-se o depoimento: "não conseguimos abordar esse assunto nem de maneira incipiente, devido às novas emergências que surgem no decorrer do projeto". Tais emer- 
gências são de vários tipos, como, por exemplo, o redirecionamento de continuidade das obras: "o projeto muda as prioridades, e fica difícil cumprir tudo, então são realizados os serviços de 'bombeiros', ou melhor, as emergências".

As assistentes apontam que, se houvesse uma priorização em se trabalhar em algumas áreas, com os esforços para cumprir o programa inicial, talvez fosse possível contemplar a proposta inicial, mas o que existe, normalmente, é uma equipe pequena lidando com inúmeras áreas. As obras são realizadas ao mesmo tempo, e isso fragmenta a condução dos trabalhos da equipe.

Os trabalhos relacionados à educação ambiental não foram realizados na Comunidade Sete de Setembro.

Foram realizadas várias entrevistas com as lideranças da Comunidade Sete de Setembro, com o objetivo de conhecer o histórico não documentado da área do antes, durante e depois da urbanização para levantar dados referentes aos aspectos técnicos das construções e gestão dos espaços exteriores, bem como detectar as principais alterações no modo de vida da população após a urbanização.

Tais entrevistas foram realizadas em diferentes fases da pesquisa, seja com a liderança da Comunidade, seja com pessoas que, apesar de não morarem na Sete de Setembro e não se constituírem liderança, possuíam larga experiência no desenvolvimento de trabalhos junto à comunidade, e que, de certa forma, acabaram estabelecendo vínculos, ostentando cumplicidade e entendimento no cotidiano dessa população. Uma delas era uma assistente social que acompanhou os trabalhos desenvolvidos pela comunidade dentro do SECOVI. Em relação às impressões anteriores à urbanização, havia áreas com muitas ligações clandestinas de energia e água, muitos usuários de drogas ou integrantes do tráfico, população mais unida e organizada em lutas para melhorias na área. "Era muito ruim; as casas eram construídas em cima do rio, quando vinha a chuva levava tudo e aí tinha que construir tudo de novo..."

Das impressões durante a urbanização, temos o Conselho Consultivo da UGP, que é criticado, pois, apesar dos representantes populares serem eleitos pelas comunidades, eles 
atuam como uma espécie de ouvinte. E não se discutiam as ações que seriam implantadas com os membros deste Conselho. Segundo a fala de um desses líderes, "o Conselho é muito rico no sentido de ter várias instâncias, no entanto, não é ouvida a voz do povo, o representante acaba exercendo o papel de informante (...) a urbanização não muda a condição de vida da favela, tudo fica quase a mesma coisa. As casas ficam todas amontoadas, as únicas casas que são urbanizadas são as do córrego".

Nas impressões posteriores à urbanização temos os relatos dos moradores: "Hoje a maioria da população mora em sobrado, tudo bem acabadinho, tem a segurança de que ninguém vai tirá-los dali, então passa massa fina, massa corrida. Isso é tão gratificante para toda a comunidade. As pessoas vêem isso como crescimento individual, no entanto, eu vejo como um todo, como é bom as pessoas poderem acreditar mais nelas, crescerem, ter a casa bonita. O cara que mora lá na casa privada pensa: o cara que mora lá na favela tem a casa melhor que a minha! Agora as pessoas têm seu carrinho na porta."

"Nós fizemos todo o trabalho de educação, mas a área verde da prefeitura não foi cuidada. Ficava sem varrer... com o passar do tempo, a população vai ocupando. Estava programado que o lixeiro passaria nas vielas para pegar o lixo, mas nunca passou, então os moradores colocam na primeira viela que encontram. Como eu vou educar o povo se a prefeitura não cumpriu a parte dela?"

"Existem muitos entupimentos nos encanamentos devido à colocação de lixo pelos moradores, deveria ter acompanhamento depois para a população aprender como se comportar. O pessoal da urbanização deveria ver os erros para eles não acontecerem novamente..."

"Várias casas têm ligação de energia direta. A Eletropaulo às vezes serve 2 a 3 famílias (...), então fica tudo camuflado. Na época quando urbanizou quem tinha dinheiro pagava o relógio, e quem não tinha ficou sem ".

"As casas estão virando prédios. Tem famílias em que uma pessoa casou, então precisa construir lá mesmo. Na verdade, a população cresceu e os equipamentos continuaram os mesmos". 
"No meio tem encanamento para água da chuva. Tem moradores que até hoje lavam as roupas e jogam a água no meio da viela, logo que já fizeram o esgoto; não era pra ter mais isso".

"Quando o tempo muda, dá um cheiro ruim em tudo. Você pode acabar de limpar o banheiro que fica cheirando. No período da chuva, acumula água nas vielas e bueiros entupidos. Fica tudo inundado".

As questões relacionadas à não existência de saneamento básico e às péssimas condições de moradia da população ficaram registradas na memória da liderança local.

As impressões e experiências vividas por estas pessoas durante a implantação das obras mostram-se de forma bastante crítica, como, por exemplo, a forma de atuação da representação popular no Conselho Consultivo.

\subsection{Levantamento dos equipamentos sociais e urbanos que atendem a população da Comunidade Sete de Se- tembro}

Tal levantamento foi realizado para verificar qual é o potencial de atendimento da população quanto aos equipamentos sociais, urbanos, bem como os serviços existentes (ver anexo 15), e também para verificar se a urbanização traz de fato um avanço em melhorias para a comunidade.

O levantamento foi realizado em 18, 19 e 21 de julho de 2001. Foi feito um roteiro semi-estruturado (Anexo 5) para coletar as informações junto aos representantes de cada instituição visitada. Durante a aplicação de tal roteiro foi verificada sua ineficiência, pois era difícil a anotação das informações de uma maneira rápida. A pesquisadora, então, passou a utilizá-lo como um referencial, e suas anotações passaram a ser registradas num caderno. 
Antes de iniciar o levantamento nas diversas instituições e áreas, foi realizada uma entrevista com uma moradora antiga da região que trabalha no SECOVI e que participa das várias atividades sociais na região. Ela nos forneceu endereços e nome de locais onde se realizavam trabalhos sociais, onde havia escolas etc.

\subsubsection{Educação}

Apesar de haver instituições de ensino público nas várias faixas etárias, foi detectado no decorrer das entrevistas que tais instituições de ensino não atendem a demanda existente na região. As igrejas, associações, entidades e comunidades organizadas procuram, de alguma forma, amenizar tal situação, procurando oferecer cursos/projetos que atendam uma parcela dos moradores. Da análise dos dados coletados, pode-se estabelecer um perfil de renda média da população, que chega no máximo a 3 salário mínimos.

\subsubsection{Equipamentos de esporte e cultura}

A área é caracterizada pela carência de espaços de lazer e cultura. O campo de futebol Jardim Reimberg é o equipamento mais próximo da Comunidade Sete de Setembro, mas há um certo monopólio exercido pelos moradores daquela área, que fica restrita a poucos usuários. No CDM ( Centro Desportivo Municipal ) visitado, pode-se perceber um certo abandono do espaço. A área encontrava-se quase vazia, somente com algumas pessoas usuárias de drogas conversando na periferia do campo. A praça Frei Damião estava com algumas crianças e jovens aproveitando seu espaço.

Percebe-se uma carência dos equipamentos de esporte, lazer e cultura, sendo que as igrejas, associações, escolas e centros procuram organizar algumas atividades para amenizar tal situação, como os exemplos da Igreja Jardim São Bernardo, que organiza festas aos finais de semana em datas comemorativas, e a escola Afrânio, que abre seus portões aos finais de semana para promover atividades junto à comunidade. O levantamento dos locais acima descritos foi realizado durante a semana e num Sábado.

Nesta coleta de dados pode-se confirmar alguns itens apontados no questionário piloto: 
a faixa de renda de população é de 3 salários mínimos, e há necessidade de melhorar a quantidade de creches, escolas e parques.

\subsubsection{Abastecimento e Bancos}

A Comunidade possui atualmente uma boa estrutura de abastecimento local com variedade e facilidade de acesso. Não se leva 15 minutos a pé para encontrar o ponto comercial mais afastado dos moradores. A implantação da maior parte dos estabelecimentos comerciais deu-se após o término das obras de urbanização; antes havia somente 13 unidades de comércio, e depois instalaram-se 66. Comparando-se com as informações obtidas pelos questionários, confirmam a falta de casa lotérica, agência de correios e Bancos apontados como necessidade.

\subsubsection{Saúde}

A região é carente de posto de saúde para atendimento primário e hospitais para atendimento secundário, pois somente o Hospital da Universidade OSEC é responsável pelo atendimento das pessoas de toda a região.

\subsubsection{Telefones Públicos}

Como a área é caracterizada por uma população de baixa renda, deveria haver mais telefones públicos que recebam e façam as chamadas. No questionário piloto, a população aponta a falta de telefones públicos como um problema a ser resolvido.

\subsubsection{Transporte Coletivo}

A região tem várias linhas, mas não oferece muita variedade, pois grande parte delas dirige-se a Santo Amaro. Há uma parcela de linhas clandestinas, o que se mostra problemático, pois a ausência de fiscalização referente à segurança e ao estado de manutenção dos veículos pode colocar em risco a vida de seus usuários. 
Segundo as informações do questionário piloto, a população sente-se satisfeita com o acesso aos meios de transporte coletivo.

\subsubsection{Limpeza}

O fato de passar o lixeiro somente duas vezes por semana faz com que os moradores acumulem volumes consideráveis de lixo, o que se observa pela quantidade deixada antes da passagem do lixeiro. Verificamos que os locais onde existe comércio dentro da favela encontram-se limpos, mas os demais locais dependem da atitude de cada morador.

No cruzamento da rua Aureliano com a Travessa Therezinha Albuquerque há uma área em que os moradores acostumaram-se a colocar lixos maiores, por exemplo, móveis, colchões etc. Após esse depósito, alguém coloca fogo para eliminá-los. Segundo informações prestadas pelos moradores, neste local anteriormente existia uma caçamba para a colocação de lixos. Depois que o lixeiro começou a passar nas ruas, ela foi retirada, mas as pessoas se acostumaram a utilizar o local como depósito de lixo. Em decorrência dos eventos elencados, encontramos a área com problemas de limpeza, mormente nos locais onde há probabilidade da ocorrência de insetos e ratos. No questionário, os moradores apontam como problema a inexistência de local adequado para o depósito do lixo.

\subsubsection{Segurança Pública}

Serviços de segurança pública são deficientes, não atendendo a população. No questionário piloto, a falta de segurança é apontada várias vezes como problema.

\subsubsection{Correios}

Grande parte dos moradores sente-se atendida na entrega das correspondências, salvo aqueles que se sentem prejudicados, pois apontam que, apesar de terem endereço, o carteiro já acostumou a fazer a entrega da forma antiga e oferece resistência em modificar sua conduta. A não entrega da conta de energia elétrica é motivo de insatisfação para parcela da população. Segundo relato de morador, a Eletropaulo passou a adotar esse tipo 
de conduta devido à inadimplência por parte dos usuários no pagamento das contas; no questionário piloto mostra a insatisfação também pela falta caixas de correios.

\subsection{Levantamento do estado de conservação e desempe- nho das obras realizadas na área}

Este levantamento foi realizado com o objetivo de detectar as principais alterações nas áreas externas às habitações, feitas pelos moradores. No projeto original da favela urbanizada, registram-se os principais problemas técnicos encontrados e mapeia-se o estado de conservação de tais áreas. No anexo 14 estão mostradas situações anteriores e posteriores a urbanização. O projeto original da favela antes de ter sido urbanizada foi elaborado em Auto-Cad e encontra-se no anexo 6. Durante as várias visitas realizadas nas áreas, observamos uma série de questões:

a) A Comunidade nomeou as principais vielas, Viela 2:Travessa Lorenzo Bartali; Viela da Paz:Travessa Therezinha Albuquerque; Viela do Sossego:Via de Pedestre Cristiano Lidarti, Viela: Via de Pedestres Fernando de Campelo; Viela 1: Via de Pedestres José Leandro Soares (ver anexo 6).

b) Nas redes de água, nem todas as residências tiveram instalado o hidrômetro, devido à falta de recursos da população para adquiri-lo. Atualmente há ligações clandestinas de água.

c) Nas redes de esgoto há ocorrência de entupimentos, e a rede de drenagem superficial não se encontra conservada apresentando, em sua grande, parte problemas de obstrução e deterioração (verificar anexo 7). Para que fosse possível avaliar as grelhas obstruídas, foi realizado um levantamento procurando quantificar a obstrução em cada uma delas. Adotou-se o seguinte critério: foi contado o número de frestas que possui cada grelha, encontrado o total de 7. Cada fresta entupida representaria, então, um valor sobre o total. Por exemplo: quando uma fresta encontrava-se obstruída, adotava-se o seguinte cálculo: $1 / 7$ x $100 \%=14,28 \%=14 \%$ da grelha obstruída. Dos 17 PVs existentes na área, 13 
encontravam-se com algum tipo de obstrução. A tabela a seguir mostra os resultados.

Tabela 5.1: Quantidade de grelhas obstruídas

\begin{tabular}{cc}
\hline \hline $\begin{array}{c}\text { Quantidade de } \\
\text { grelhas obstruídas }\end{array}$ & $\begin{array}{c}(\%) \text { de } \\
\text { obstrução }\end{array}$ \\
\hline \hline 2 & 14 \\
\hline 4 & 29 \\
\hline 1 & 57 \\
\hline 3 & 72 \\
\hline 1 & 86 \\
\hline 2 & 100 \\
\hline \hline
\end{tabular}

- A grande quantidade de grelhas entupidas em toda a área seguramente causa transtornos aos moradores nos períodos das chuvas, pois impossibilita o escoamento das águas, e as vielas acabam servindo de condutoras para as águas pluviais da parte superior para a inferior, contribuindo para os alagamentos nessas regiões.

d) Na rede elétrica, nem todas as casas tiveram instalado o medidor, e parte da população é obrigada a fazer ligações clandestinas. Atualmente, grande parte das caixas instaladas nas calçadas das ruas encontram-se deterioradas e oferece riscos de acidentes. A fiação aérea externa instalada encontra-se a pouca altura, e por vezes é derrubada por caminhões de entrega que passam inadvertidamente. Tais fios encontram-se com emendas em vários locais.

e) A iluminação pública é praticamente inexistente. Encontrou-se apenas um poste que possui luminária em funcionamento, localizado na esquina da rua Aureliano com a Therezinha Albuquerque.

f) Das 18 vielas existentes no Projeto, $6(33,3 \%)$ foram fechadas com portões pelos moradores e transformadas em áreas privadas, restritas a alguns moradores, que passaram a usar tais espaços para o lazer das crianças ou ampliação da casa. As vielas fechadas são 
as: $18,10,9,7,6$ e 3 . Tal registro encontra-se no anexo 7 .

O bloqueio de vielas antes destinadas ao acesso de moradores a suas residências, ou até mesmo interligando uma rua com outra, mostra claramente o conflito entre o público e o privado. Os moradores não legitimam o uso coletivo de algumas vielas, e tais áreas públicas passam a ser coletivizadas por um número menor de moradores. Há casos em que moradores, individualmente, apropriam-se dessas áreas, transformando-as em áreas privadas, seja para o benefício de um grupo pequeno ou até mesmo individual. Percebemos que algumas vielas foram fechadas com o intuito de aumentar a segurança, pois as crianças passaram a brincar nessas áreas como se fossem um quintal coletivo. Algumas foram utilizadas para promover a ampliação da casa, e outras transformadas em área para lavagem de roupas e outras atividades.

g) Grande parte das árvores catalogadas estão situadas dentro do terreno do morador, somente duas estão nas calçadas das ruas. As áreas verdes são mínimas, e várias delas atingem no máximo $2 \mathrm{~m} 2$ (Ver anexo 8).

h) Falta local apropriado para o depósito do lixo, fato que se confirmou, pois foram encontradas poucas lixeiras, sendo sua localização nas vias principais. O lixo dos moradores das vielas onde o lixeiro não passa acaba sendo depositado na primeira esquina onde passa o caminhão. Todos esses problemas foram apontados no questionário piloto.

\subsection{Levantamento das atividades dos moradores nos es- paços exteriores à habitação}

Nesta parte do trabalho, procuramos observar como é o cotidiano da população moradora da área, fazendo um levantamento das principais atividades desenvolvidas pelos moradores nas áreas externas às habitações.

Os levantamentos foram realizados em dois dias alternados: em 19/07/01, uma quintafeira, das 10 h30 às 16h15, e em 21/07/01, um sábado, das 10h00 às 15h00 horas. Encontram- 
se respectivamente registrados nos anexos 9 e 10.

Para a notação das informações, estabeleceu-se um roteiro de percurso a ser seguido durante as observações, iniciando pela rua Aureliano de Beruete - Via de Pedestres José Leandro Soares - Via de Pedestres Fernando de Campelo - Viela 5 - Travessa Therezinha Albuquerque - Travessa Lorenzo Bartali. Durante o percurso, foram anotadas as atividades ocorridas nas Vielas, foram anotados o início e o término de cada percurso, anotados os locais, a quantidade de pessoas envolvidas, sua faixa etária e o tipo de atividade desenvolvida pelos moradores.

As atividades desenvolvidas pelas crianças até 12 anos são: jogar bola, correr de pegapega, jogar bolinhas de gude, bater figurinhas, conversar, soltar pipas etc.

Observamos na quinta-feira a existência de dois locais com maior concentração de crianças brincando: a Travessa Lorenzo Bartali, próximo à viela 15, e também a Via de Pedestres Cristiano Lidarti. Já no sábado, pudemos perceber que a concentração diminuiu. Esse fator pode ser justificado na Via Cristiano Lidarti devido ao estacionamento de vários automóveis nas calçadas e em parte da rua. Já na Lorenzo Bartali, a concentração de crianças diminuiu, aumentando o número de adultos junto a elas.

Durante as observações constatou-se que as atividades de lazer no interior da favela acontecem em locais específicos, o que desperta várias questões. Porque esses locais são os mais escolhidos? Será em decorrência de um maior número de crianças na redondeza? Ou ali os vizinhos são mais "tolerantes"? Seria mais seguro? Ou mais agradável? Notam-se, também, problemas onde os carros ocupam os espaços das atividades de lazer, ou seja, a presença de carros estacionados no mesmo local em que as crianças brincam reduz o número de crianças brincando durante o final de semana. Curioso é que nesse momento aumenta o número de pessoas em casa.

Dos adolescentes, grande parte encontrava-se durante a semana para conversar em frente a um bar que oferece fliperamas, ao lado da escadaria da Travessa Lorenzo Bartali e também na Viela 15, esquina com a Aureliano de Beruete, soltando pipas. Aos sábados, os pontos se repetiram, porém encontraram-se menos jovens; as atividades de lazer se 
repetiram nos mesmos locais durante os vários dias. Podemos indiciar que a falta de área de laser é um problema também presente neste grupo.

Os adultos e idosos, tanto homens como mulheres, ficam próximos ao Bar do KK, na esquina da Aureliano com a Travessa Therezinha Albuquerque. Estes desempenhavam atividades diversas, tais como conversar, tomar sol, ver as crianças brincarem. Por que isso ocorre? Há indícios de que os moradores criam pontos de encontro para conversar e cuidar da proteção das crianças; isto porque os indícios da falta de segurança e de lazer é um problema sério para este grupo.

Tentando entender como se desenvolve o cotidiano dentro da Comunidade Sete de Setembro, a pesquisadora, apesar de sair a campo sem a intenção de fazer entrevistas num primeiro momento, decidiu conversar informalmente com pessoas pertencentes a vários grupos etários.

O objetivo primeiro foi entender o porquê da preferência de alguns locais e não outros. No entanto, após a pesquisadora se apresentar e expor o objetivo da pesquisa, os próprios moradores sentiam-se incentivados a falar sobre seus anseios, ela então achou o momento apropriado para fazer perguntas direcionadas à pesquisa:

Como era a Sete de Setembro antes da Urbanização? O que era bom e o que não era ? E depois da Urbanização?

A cada resposta dada, a pesquisadora inseria outra questão relacionada ao questionário piloto para poder entender melhor seus relatos. Tais informações eram registradas e posteriormente analisadas, e a partir daí pudemos confirmar os indícios apontados durante as observações pode-se entender também um pouco mais da visão do usuário em relação à comunidade, antes e depois da urbanização. Verificamos que a cada faixa etária as necessidades e visões sobre a área se diferenciam. Então, procuramos agrupar por faixa etária as informações a seguir:

Conversas com grupo de 6 crianças na faixa etária de 8 a 11 anos. As crianças que tinham idade de 10 e 11 foram as que mais contribuíram com as informações.

Como era o bairro antes da urbanização? "Antes tinha córrego e barracos, antes eu gos- 
tava de fazer bolinha no barro, era bom, mas do resto não. Por causa do córrego, chovia e inundava tudo, e eu perdia todos os meus brinquedos. Agora, às vezes fica inundado, mas a gente desentope”;"Antes brincar era melhor, pois não passavam carros e tinha mais espaço. Nos finais de semana, enche a rua toda de carro, e quando tem festas nas casas por aqui.", "As casas eram bem piores, algumas pessoas ficaram em casas de ferro até construir as ruas e os sobradinhos. Os sobradinhos eram estranhos no inicio, e agora são comuns, pois agora convivemos, entramos e conhecemos.", "A luz acabava bastante antes, e agora é raridade, só quando chove muito forte, ou é instalado algum telefone.”, "Não me lembro onde era colocado o lixo, mas agora é colocado no canto da Viela 15.","Depois da construção, teve uns lugares onde tinha pracinha: a gente gostava muito da pracinha. Era tudo verdinho, tinha árvore e banquinho, a gente gostava de brincar, mas faz um a dois anos que tiraram. Destruíram quase toda a nossa rua, que tinha verdinho em quase toda ela. "Se eu pudesse eu transformaria essa rua toda em um parquinho.", "Hoje a gente não tem lugar pra brincar: ou a gente vai lá no Conjunto Palmares, mas lá não pode, pois é particular, e o guarda manda a gente ir embora, ou então a gente tem que ir lá no parquinho da Vila Natal, mas é muito longe."

Foi entrevistado um grupo de 8 jovens, com idade de 17 a 22 anos. Desses jovens, um está trabalhando e dois estão estudando. Nenhum destes jovens possui o primeiro grau completo.

Como era a área antes da urbanização? "Antes tinha um campinho onde era o depósito de gás, era bom"; "Agora é que está ruim; há violência policial, não deixam a gente ter liberdade"; “Na escola tem que ir bonitinho, senão não tem vaga, não tem supletivo na região.", O que falta? "Salão de festas, no Secovi, quando tem festa tem que pagar, e a gente não tem dinheiro";"Antes tinha a quadra do Herbert para jogar, e agora não tem mais; eles vão construir salas de aulas”;“Trabalho: exigem experiência e estudo, e a gente acaba não conseguindo";"Iluminação da favela: pública não tem; até as 22 horas é seguro, mas depois não. “,"O que tem de legal aqui é poder conhecer todo mundo; tem gente que está aqui há 20 ou 30 anos.” 
Foram ouvidos também adultos que contribuíram com sua opinião, J e M (65 e 58 anos). Como era antes da urbanização? Para o Sr. J, "tudo está ótimo, muito melhor do que antes, que só tinha esgoto e terra".

Como está a área depois de urbanizada? "As contas de luz, a Eletropaulo não está entregando; o morador tem que buscar na Agência no Parque das Árvores, levando 1 hora e 30 min para ir e vir";"As cartas ainda são entregues no Bar do KK, na esquina";"o policiamento nas vielas, quando é solicitado, não aparece"; e "a limpeza das ruas é realizada pelos moradores."

O resultado das observações e conversas informais mostra-nos as satisfações e insatisfações que de um modo geral, estendem-se a toda Comunidade. As crianças e jovens estão parcialmente satisfeitos; eles reconhecem as melhorias, mas a falta de arborização e áreas de lazer é o principal ponto de insatisfação; devido à falta de segurança muitas crianças e jovens são obrigados a ficar dentro de casa.

Para os adultos as satisfações são maiores, pois os grandes problemas - os esgotos a céu aberto, asfaltamento de ruas, iluminação, com toda a obra de urbanização foi solucionado. A insatisfação está relacionada à gestão da área após a urbanização, como a limpeza das área externas.

\subsection{Entrevista semi-estruturada com grupos focais}

Foi elaborado um roteiro semi-estruturado para entrevista com os moradores, priorizando três grupos focais constituídos basicamente por crianças entre 7 a 12 anos, jovens entre 13 e 17 anos e adultos acima de 25 anos. Tais roteiros encontram-se respectivamente nos anexos 12 e 13.

A forma como as questões do roteiro semi-estruturado foram elaboradas, bem como a determinação da faixa etária de cada grupo, surgiu da análise do questionário piloto, da experiência das conversas informais realizadas durante o levantamento das atividades realizadas pelos moradores nos espaços públicos da Comunidade, da consulta realizada à profissional da área de comunicação e da fundamentação teórica apresentada por BECH- 


\section{TEL (1987) e LUDKE; ANDRÉ (1986).}

Após a formulação do roteiro, a pesquisadora estabeleceu um novo contato com uma representante da comunidade que trabalha no Secovi, e com o assistente social da Prefeitura responsável para que pudessem ajudar na escolha e disponibilização de locais onde a pesquisa pudesse ser realizada.

Inicialmente, pensou-se em se usar Secovi, mas como o espaço não abre aos finais de semana, uma moradora disponibilizou sua casa para a realização da pesquisa.

Com o contanto inicial através de Dona M, que é conhecedora de quase toda a Comunidade, estabeleceu-se um vínculo de confiança, que facilitou a autorização dos pais para que os adolescentes e crianças participassem da pesquisa. Ficou estabelecido que cada grupo focal deveria ser constituído por três pessoas (foram convocadas quatro para substituição no caso de faltas), das faixas etárias descritas anteriormente e que morassem na Comunidade antes das obras de urbanização.

O dia e horário foram estabelecidos conforme a disponibilidade dos integrantes do grupo ficando acordado o dia 29/06/2002, das 14 h00 às 15 h00 com o grupo de crianças, das 15 h00 às 16 h00 com jovens, e das 16 h00 às $17 \mathrm{~h} 00$ com os adultos.

A pesquisadora, em conjunto com a jornalista especialista em comunicação, conduziu as entrevistas. O ambiente foi preparado com a colocação de cadeiras em forma de círculos e uma mesa de canto com alguns lanches e refrigerantes oferecidos aos moradores. Esta disposição teve por objetivo propiciar um clima de descontração entre entrevistados e entrevistadores.

Feita uma apresentação da jornalista, da pesquisadora e dos objetivos da pesquisa, enfatizando o caráter acadêmico, iniciou-se a pesquisa. Foi solicitado ao grupo o preenchimento da primeira página do roteiro; quanto à segunda parte, foi avisado que nós faríamos em conjunto de forma oral e que depois a pesquisadora preencheria as tabelas. A permissão para a gravação das entrevistas foi solicitada e atendida pelos moradores, aos quais foi garantido o sigilo pessoal; as perguntas eram feitas pela pesquisadora enquanto a jornalista, em paralelo, observava o comportamento dos entrevistados, bem como anotava as infor- 
mações prestadas por eles; em alguns momentos, fazia-se interferências para elucidar o entendimento de algumas questões apontadas. No final de cada entrevista, agradecia-se aos contribuintes e avisava-os que, posteriormente, traríamos os resultados da pesquisa para a Comunidade; a jornalista então, acompanhava-os no lanche, enquanto a pesquisadora organizava os materiais para o grupo seguinte.

Com relação aos resultados e análise dos dados; o grupo de jovens foi constituído por 3 adolescentes com idades entre 15 e 16 anos; estão fazendo o segundo grau, são solteiros, não trabalham e nasceram na Comunidade; todos moram em casa própria e apontam as reformas nas casas após a urbanização. Em tais reformas forma apontados os seguintes itens: colocação de piso, pintura, reboco, colocação de telhado, de laje e aumento da área de comércio.

Não houve alteração no número de pessoas que moravam na casa. Depois da urbanização, todos participaram de alguma atividade na Comunidade, fazendo cursos profissionalizantes.

Os chefes de família são os pais, e numa família uma das filhas trabalha também. Somente uma pessoa respondeu sobre a renda familiar, que alcançava cerca de $\mathrm{R} \$ 1.400,00$ por mês.

As opiniões do grupo em relação à Comunidade antes e depois da urbanização encontramse registradas na tabela a seguir.

O aspecto considerado positivo para o grupo antes da urbanização é a possibilidade das crianças de terem alguma alternativa para o lazer mesmo que realizado numa área sem condições mínimas de saneamento, e há mais áreas verdes.

Quanto às questões de ligações clandestinas e falta de energia elétrica, as condições de saneamento, transporte coletivo e comércio foram itens problemáticos anteriormente, com os quais agora os moradores apresentam-se satisfeitos.

Os itens relacionados a violência, falta de segurança e locais adequados para a disposição e coleta do lixo são problemas levantados, anteriormente, e até o momento não houve solução. A falta de estabelecimentos como bancos ou postos de saúde é sentida pela po- 
Tabela 5.2: Resultado da entrevista com grupo de jovens

\begin{tabular}{|c|c|}
\hline $\begin{array}{l}\text { O que você mais gostava } \\
\text { antes da urbanização? }\end{array}$ & $\begin{array}{l}\text { O que você não gostava } \\
\text { antes da urbanização? }\end{array}$ \\
\hline $\begin{array}{l}\text { - brincadeiras com ratos nos } \\
\text { esgotos e no barro } \\
\text { - tinha mais áreas verdes } \\
\text { - comércio }\end{array}$ & $\begin{array}{c}\text { - falta de energia e ligações } \\
\text { clandestinas de energia; } \\
\text { - ampliaram as casas e destruíram as áreas verdes; } \\
\text { - falta local para colocar os lixos, era colocado } \\
\text { no córrego; } \\
\text { - falta de transporte coletivo; } \\
\text { - violência. }\end{array}$ \\
\hline O que melhorou? & O que piorou? \\
\hline $\begin{array}{c}\text { - fornecimento de energia; } \\
\text { - iluminação } \\
\text { - saneamento e asfalto nas ruas } \\
\text { - comércio } \\
\text { - transporte }\end{array}$ & $\begin{array}{c}\text { Todos acham que nada piorou } \\
\text { - O que ainda está ruim ? } \\
\text { - Falta de árvores; } \\
\text { - Falta de espaço para áreas verdes; } \\
\text { - Aumento de população na área; } \\
\text { - Falta de acesso do lixeiro e as ruas } \\
\text { ficam cheias de lixo; } \\
\text { - Falta de lazer; } \\
\text { - Droga/ segurança/ violência na } \\
\text { adolescência; } \\
\text { - Falta de posto de saúde; } \\
\text { - Falta banco; } \\
\text { Alguns focos de dengue. }\end{array}$ \\
\hline
\end{tabular}

pulação.

Comparando os resultados obtidos por este grupo aos das entrevistas realizadas com o de crianças e jovens durante o levantamento das atividades realizadas nas áreas externas a habitação, observamos semelhança nas respostas.

A ausência de crianças de 7 a 12 anos que se lembrassem da fase anterior à urbanização e se encaixassem na faixa etária estipulada inicialmente foi decisiva para adoção de outro método (resgate da infância dos adolescentes entrevistados), sem retorno à Comunidade para entrevistar tal grupo.

Para a entrevista, um total de sete pessoas constituíam o grupo de adultos, sendo que três são efetivamente moradores da Comunidade e dois moram na fronteira. Desses dois últimos, , apenas um mostrou-se completamente inserido no cotidiano, e foi incorporado no 
grupo focal estabelecido. O outro foi desconsiderado, bem como dois outros integrantes do grupo, por serem representantes de comunidades vizinhas que souberam da entrevista e quiseram participar. Para não haver constrangimentos, de acordo com a sugestão da jornalista, foi permitida a participação, mas depois foram desconsideradas para análise restando um grupo de quatro pessoas como parte da pesquisa.

Em relação à caracterização do grupo, veremos que a faixa etária variou de 30 a 59 anos, constituído por 3 senhoras e 1 senhor. Não possuem o primeiro grau completo, as profissões variaram entre autônoma, pedreiro, monitora e 1 copeira; a renda média é de 3 salários mínimos; todos vieram do nordeste, sendo que o morador mais antigo está há 25 anos na área, e o mais novo há 13 anos e todos com casa própria. Em apenas 01 família houve acréscimo no número de pessoas devido a casamento na família, nas demais não houve alteração. Em relação à participação das pessoas nas atividades da Comunidade, o grupo ficou dividido, metade dele nunca participou.

Em relação a alterações na habitação, todos responderam que fizeram alguma reforma sendo os itens mais apontados: reboco da parte externa da casa, colocação de telhado novo, de piso, de laje, ampliação da casa, mudança da área externa, adaptação de área para comércio etc. Os resultados da segunda etapa do roteiro encontram-se na tabela a seguir. No transcorrer da entrevista, observou-se que as péssimas condições de saneamento fora o item que mais incomodava os moradores. A falta de pavimentação, grande número de ligações clandestinas de água e eletricidade, pouco comércio e o transporte público ineficiente foram itens considerados negativos anteriormente, no entanto superados após a urbanização.

A segurança é o único fator que este grupo considera positivo antes da urbanização, e atualmente é um problema principalmente para os jovens.

Em relação à gestão da área, a falta de manutenção das redes de esgoto, é considerada causadora de parte dos problemas de entupimento devido à falta de conscientização. A fiação aérea externa baixa, a inexistência de iluminação pública e a falta de área destinada ao lazer são questões relacionadas à falha que é sentida pela população, e faz-se necessário uma revisão para projetos futuros. 
Tabela 5.3: Resultado da entrevista com grupo de adultos

\begin{tabular}{|c|c|}
\hline $\begin{array}{l}\text { O que você mais gostava } \\
\text { antes da urbanização ? }\end{array}$ & $\begin{array}{l}\text { O que você não gostava } \\
\text { antes da urbanização? }\end{array}$ \\
\hline Segurança & $\begin{array}{c}\text { - ratos, lixo, esgoto, barro; } \\
\text { - parte de baixo da favela os } \\
\text { problemas eram mais graves; } \\
\text { - acessibilidades aos carros; } \\
\text { - enchentes e alagamentos; } \\
\text { - mau cheiro, principalmente no verão; } \\
\text { - dificuldade de locomoção devido à lama; } \\
\text { - pouco comércio e transporte coletivo; } \\
\text { - ligações clandestinas de água; } \\
\text { - violência. }\end{array}$ \\
\hline 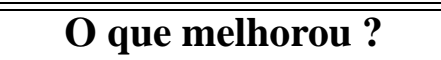 & O que piorou? \\
\hline $\begin{array}{l}\text { - acessibilidade } \\
\text { - Transporte, mas ainda } \\
\text { precisa melhorar mais } \\
\text { - Condições de } \\
\text { saneamento }\end{array}$ & $\begin{array}{c}\text { - rede elétrica externa baixa } \\
\text { e falta de iluminação pública; } \\
\text { - manutenção da rede de esgoto } \\
\text { (perto da viela } 15 \text { sempre dá problema); } \\
\text { - Conscientização da população com o } \\
\text { cuidado e utilização das áreas públicas; } \\
\text { - Demora de atendimento pelos responsáveis } \\
\text { pela manutenção da rede de esgoto; } \\
\text { - Falta de posto de saúde; } \\
\text { - Droga/ segurança/ violência na } \\
\text { adolescência; } \\
\text { - Falta de posto de saúde; } \\
\text { - Falta de área de lazer; }\end{array}$ \\
\hline
\end{tabular}

Os pais atribuem a falta de áreas e atividades de lazer destinadas às crianças e aos jovens como um principal fator da violência existente na Comunidade.

O posto de saúde é um equipamento solicitado neste grupo, nos de jovens bem como nas entrevistas realizadas anteriormente, portanto é fundamental a instalação de um posto para população da região.

Em relação à satisfação dos moradores, eles reconhecem que as obras trouxeram grandes benefícios para a vida da Comunidade, sentindo-se satisfeitos com o resultado. Exemplo disso é o orgulho que sentem por morar na Comunidade, não querendo trocar por nenhum outro local, o que pode ser visto nas melhorias feitas nas casas. E em suas falas as 
melhorias também aparecem no meio de transporte, comércio etc. 


\section{Capítulo 6}

\section{Comentários finais}

Consideramos que a nossa proposta inicial de analisar um projeto de urbanização de favelas e de retratar o grau de satisfação dos moradores em relação às intervenções efetuadas, utilizando o Método de Avaliação Pós-Ocupação (APO) foi alcançado com sucesso, na medida em que foi possível retratar tal objetivo e ainda superar tal proposta, a partir da implementação de discussões e da apresentação de sugestões para projetos similares, apontando erros e acertos no processo.

Nesse contexto, o fato de termos contatado nas entrevistas várias pessoas com diferentes cargos e responsabilidades de atuação no Programa Guarapiranga, bem como no projeto específico de urbanização da Comunidade, possibilitou uma visão ampla dos diversos aspectos envolvidos num Projeto de Urbanização. Nesse sentido, acreditamos que considerar a visão dos moradores é fundamental, pois estes são os beneficiados diretos das obras realizadas e, quase como "peças-chave", únicos no sucesso ou fracasso do Programa como um todo, na medida em que o tipo de comportamento e relação que tecem com o meio, como, por exemplo, o uso inadequado da rede de drenagem superficial ou da rede de esgoto, provocando entupimentos devido à má utilização etc., pode ser decisivo para a conservação de cada uma das obras de urbanização realizadas dentro da bacia, interferindo diretamente no desempenho do Programa.

Com efeito, pudemos constatar que a Comunidade, na sua maioria, sente-se bastante satis- 
feita com o resultado das obras realizadas, o que nos demonstra que o objetivo do projeto atendeu em parte as expectativas dos moradores. Entretanto, após o término do projeto, surgiram queixas sobre a "má gestão"dos espaços públicos no interior da Comunidade, devido a problemas como, por exemplo, o entupimento da rede de drenagem superficial, a destruição e ocupação das poucas áreas verdes preservadas no interior da Comunidade, a falta de limpeza das áreas públicas etc. Contudo, parte desses problemas é provocada pelos próprios moradores, que não se sentem compromissados nem responsáveis pela preservação das obras realizadas, cobrando apenas dos órgãos públicos toda e qualquer ação no sentido de melhorar essa gestão dos espaços.

Nesse sentido, acreditamos que seria necessária uma maior conscientização da população através do desenvolvimento de trabalhos de educação ambiental, possibilitando, dessa forma, a utilização das áreas públicas e verdes de maneira consciente no interior da Comunidade e a conseqüente gestão da bacia de maneira sustentável, o que, de fato, estava previsto. No entanto, resgatando o histórico do trabalho de acompanhamento social nas áreas urbanizadas, verificamos que não houve nenhum tipo de acompanhamento social e físico juntos aos moradores da Comunidade, após a conclusão dos trabalhos na Comunidade Sete de Setembro, o que também pode ser constatado em várias outras obras de urbanização do Programa Guarapiranga. Segundo relatos da equipe, tais trabalhos não foram implementados devido a aspectos de ordem financeira ${ }^{1}$ apontados pelos técnicos e também em decorrência dos problemas no encaminhamento das obras ${ }^{2}$, descritos pela assistência social.

Assim, é possível observar, entre os moradores, uma mentalidade baseada numa espécie de troca, em que o cuidado com os espaços públicos fica vinculado à sua manutenção pelo poder público, demostrando, portanto, que não existe um sentimento de propriedade que permita uma relação de compromisso, responsabilidade e cuidado com esses espaços

\footnotetext{
${ }^{1}$ Especialmente a falta de recursos direcionados a programas nesta área.

${ }^{2}$ As assistentes consideram que os trabalhos, atualmente, têm de ser realizados de forma fragmentada, pois são responsáveis pelo acompanhamento simultâneo de várias obras, e assim terminam por realizar, além dos serviços básicos de cadastramento e acompanhamento junto aos técnicos, a assessoria aos moradores.
} 
como pertencentes a todos, individual e coletivamente.

Por isso, acreditamos que a possibilidade de gestão da área urbanizada de maneira sustentável está intimamente ligada a fatores de ordem técnica, como, por exemplo a conservação, manutenção e melhoria dos serviços públicos por parte dos órgãos responsáveis. Contudo, é necessário considerar também os aspectos de ordem social, tais como o compromisso da população com a preservação e utilização adequada dos recursos disponíveis, tão importante quanto o compromisso do poder público com a Comunidade. Assim, pensamos que talvez a realização de um trabalho de acompanhamento social e do pós-uso físico das áreas, junto aos moradores da Comunidade Sete de Setembro, por um determinado período após a urbanização, poderia ter colaborado positivamente para a manutenção das benfeitorias realizadas para os dos moradores ${ }^{3}$.

Ainda em relação à utilização dos espaços públicos, constatamos que, excluindo a viela 18 , as demais que foram fechadas pelos moradores não se interligam às ruas, que foram transformadas em espaços coletivizados para sua utilização, passando a funcionar como lavanderias, quintais para as crianças brincarem ou até mesmo para ampliação das habitações. Isso demonstra que elas não tiveram sua função legitimada para o que foram projetadas; no entanto, passaram a ter mais utilidade para a população, na medida em que antes eram consideradas perigosas devido à falta de iluminação e também por suas dimensões muito estreitas. Talvez fosse mais adequado a elaboração de projetos que incluíssem essa demanda de pequenos espaços coletivizados dentro da favela pelos moradores para uso comum.

Por outro lado, ao longo de nosso trabalho foi possível constatar, a partir da visão dos engenheiros e assistentes sociais que participaram de várias obras de urbanização do Guarapiranga, que nas áreas onde existe uma liderança consolidada e a população é participativa é estabelecida logo no início das obras uma relação de confiança e cumplicidade nas ações entre a equipe social e técnicos e a população local, facilitando, desta forma, o desenvol-

\footnotetext{
${ }^{3}$ Tais como adequação da infra-estrutura viária, drenagem e instalação das redes de água e esgoto e energia elétrica.
} 
vimento dos trabalhos de urbanização. Assim, o fato de a Comunidade Sete de Setembro estar composta de uma forte organização comunitária trouxe muitos benefícios na implantação das obras. Isto porque a preocupação dos moradores se dava mais no plano coletivo, ou seja, eles estavam mais interessados nos resultados coletivos das ações efetivadas e não apenas no plano individual, limitado a questões como, por exemplo, se seu muro vai cair, se sua casa vai ser retirada etc. Comparando essa postura predominante na Sete de Setembro com o comportamento recorrente em várias outras áreas, pudemos perceber como isso interfere a posteriori na preservação das áreas obras realizadas. Assim, comparando o estado de conservação das obras da Comunidade com outras áreas urbanizadas no mesmo período, a Sete de Setembro estava visivelmente melhor preservada.

Nesse contexto, talvez fosse possível pensar no estabelecimento de projetos buscando fortalecer as lideranças locais, sendo que estas poderiam ser constituídas a partir de uma capacitação organizada pela partilha das experiências de outras lideranças já consolidadas, sendo que estas poderiam realizar a mediação entre a comunidade e os responsáveis pelo projeto, o que talvez estimulasse a formação de líderes e a participação social em outras áreas onde está prevista a implantação de novos projetos.

Dessa forma, entendemos que este estudo pode ser considerado como uma ferramenta para reflexão dos agentes envolvidos na elaboração de projetos similares, na medida em que apresenta os diferentes pontos de vista de pessoas que estiveram envolvidas tanto no processo de formulação quanto de implementação e gestão de programas de urbanização de favelas.

A partir do resgate da fase de implantação das obras de urbanização da Comunidade Sete de Setembro, pudemos verificar que durante sua execução ocorreram vários imprevistos técnicos, como, por exemplo, o abalo das estruturas de algumas habitações já existentes e até mesmo seu desmoronamento, devido à utilização de maquinários que, de certa forma, não eram tão adequados ao tipo de obra realizada. Dessa maneira, pensamos que se houvesse condições de optar por algum tipo de equipamento alternativo mais apropriado 
especialmente para a utilização nas áreas de fundo de vale, onde a ocorrência de desmoronamentos é grande, talvez fosse reduzido o impacto nas estruturas das habitações, ao contrário do que ocorre atualmente.

No que diz respeito à relação com a estrutura política do Conselho Consultivo, que agrega representantes do Estado, dos municípios e da sociedade civil, percebemos que há uma incompatibilidade entre as expectativas da Comunidade e o que está sendo oferecido, ou seja, o Conselho foi elaborado com o propósito de ser consultivo, no entanto, a população gostaria que ele passasse também a deliberar e, por conseguinte, alcançar um maior papel nas discussões, representando melhor o interesse da comunidade.

Pensando sobre o oferecimento dos serviços de abastecimento de água e energia, mesmo após a urbanização ainda é presente a questão da clandestinidade. Assim, constatamos que há um boicote no pagamento de tais serviços devido à existência de ligações clandestinas que, atualmente, ocorrem em menor número, quando comparados aos números anteriores ao processo de urbanização. Segundo os moradores, a energia elétrica só foi instalada nas habitações cujos moradores tinham recursos para comprar a caixa de entrada. Ou seja, vários deles foram excluídos devido à falta de recursos econômicos.

Retomando a proposta inicial deste estudo, ou seja, identificar o grau de satisfação dos moradores da Comunidade Sete de Setembro, consideramos a necessidade de realizar o cruzamento das diferentes visões e experiências acerca do processo com o intuito de explicitar os diferentes interesses envolvidos. Assim, a visão dos técnicos e assistentes sociais demonstra uma grande satisfação, na medida em que não tiveram problemas com a população da área durante a implantação da obra, como, por exemplo, roubo de equipamentos e de materiais de trabalho da equipe, fato comum em outros locais ${ }^{4}$. No entanto,

\footnotetext{
${ }^{4}$ Houve, contudo, problemas não previstos inicialmente, como, por exemplo: a construção (4), reconstrução (5) e invasão (1) de unidades habitacionais; a ocorrência de remanejamentos (ver. Cap. 3) previstos (28) e realizados (53); remoções (Ver Cap.3) previstas (4) e realizadas (7); utilização de alojamentos (7); invasão de área no interior da favela por 4 famílias. Tais aspectos, além dos financeiros e climáticos, contribuíram para o atraso do andamento das obras, sendo prevista a conclusão em 10 meses e ocorrendo em 15 meses. Esses aspectos, entretanto, não interferiram na satisfação dos assistentes e técnicos acerca da implantação da obra porque são elementos, de certa forma, comuns nesse tipo de projeto.
} 
para os moradores, que ficaram no local e vivenciam a gestão desses espaços públicos, pudemos constatar uma certa frustração de suas expectativas iniciais, visto que esperavam o retorno desses técnicos da construtora à área e o acompanhamento social do pós-uso.

Particularmente, é importante ressaltar que o desenvolvimento dos trabalhos de coleta de material bibliográfico e informações com profissionais envolvidos nos projetos de urbanização do Programa Guarapiranga foi atingido com êxito. Consideramos que este aspecto merece destaque porque muitas vezes o pesquisador esbarra em questões burocráticas e falta de acesso às informações junto às instituições e órgãos responsáveis, o que dificulta o cumprimento dos objetivos e desenvolvimento do trabalho. Nesse sentido, foi possível a apropriação de diferentes pontos de vista, o que permitiu uma visão ampla do processo.

Dessa forma, a Avaliação Pós-Ocupação (APO) se constituiu num método bastante confiável, pois todos os procedimentos, tais como questionário piloto, observações comportamentais e entrevistas, convergiram no sentido de retratar resultados similares em relação à satisfação da Comunidade.

Nesse sentido, gostaríamos de ressaltar a importância deste trabalho, na medida em que traz informações e aponta para possibilidades de repensar os Projetos de urbanização de favelas, demonstrando, contudo, que tal assunto não se esgota com nossas considerações.

Assim, pensamos ser importante a realização de trabalhos que desenvolvam parâmetros para o dimensionamento de projetos de urbanização de favelas. Da mesma forma, seriam também, a nosso ver, fundamental a realização de estudos que analisassem a gestão do Programa sob o ponto de vista institucional, buscando apontar as principais dificuldades e soluções para os problemas encontrados. Da mesma maneira, consideramos relevante também a necessidade da realização de pesquisas comparativas que comportem as variáveis entre a previsão de custos versus o valor real gasto durante a implementação de projetos similares, buscando levantar os fatores que provocaram tal diferença, contribuindo para que tais projetos possam alcançar, talvez, orçamentos mais próximos à realidade. 


\section{Referências bibliográficas}

ABIKO, A . K. Introdução à Gestão Habitacional. São Paulo, EPUSP, 1995. (Boletim Técnico da Escola Politécnica da USP. Departamento de Engenharia de Construção Civil, $\mathrm{BT} / \mathrm{PCC} / 12)$.

ANDRADE, M.; GERHARDT, S.; PICADO, G. Avaliação e intervenção nos espaços públicos baseados em premissas ambientais e tecnológicas. In: ENCONTRO NACIONAL DE TECNOLOGIA DO AMBIENTE CONSTRUídO,8., Salvador, 2000. Anais. Salvador, 2000. p.1447-1454.

ALMEIDA, A.P. Indicadores de salubridade ambiental em favelas urbanizadas: $O$ caso de favelas em áreas de proteção ambiental. 1999. Tese(doutorado)- Escola Politécnica, Universidade de São Paulo. São Paulo, 1999.

ALMEIDA, A.P. Urbanização de favelas em Diadema, no período de 1993 a 1988. 1994. Dissertação(mestrado)- Escola Politécnica, Universidade de São Paulo. São Paulo, 1994.

BECHTEL, R.; MARANS, R.W.; MICHELSON, W.Methods in environmental and behavior research. New York: Van Nostrand Reinhold Company, 1987.

CARR, S. el al. Public Space. New York: Cambridge Universit Press, 1992.

CNEC - Consórcio Nacional de Engenheiros Consultores S.A; JNS - Engenharia, Consultoria e Gerenciamento S/C Ltda.Programa de Saneamento Ambiental da Bacia do Guarapiranga: Plano de Desenvolvimento e Proteção ambiental da Bacia do Guarapiranga - Diagnóstico Ambiental, Vol.1. São Paulo: Secretaria de Recursos Hídricos, 
Saneamento e Obras do Estado de São Paulo, jan. 1997.

COBRAPE - Companhia Brasileira de Projetos e Empreendimentos. Programa de Saneamento Ambiental da Bacia do Guarapiranga: Descrição e Justificativa, Vol.1. São Paulo: Governo do Estado de São Paulo, out. 1991.

Consórcio JNS-HagaPlan.Programa de Saneamento Ambiental da Bacia do Guarapiranga: Relatório de atividades - dados técnicos, Vol.2. São Paulo: Secretaria Municipal da Habitação da Prefeitura de São Paulo, Programa Guarapiranga, dez. 1998.

Consórcio JNS-HagaPlan.Programa de Saneamento Ambiental da Bacia do Guarapiranga: Relatório de atividades, Vol.1. São Paulo, Secretaria Municipal da Habitação da Prefeitura de São Paulo, dez. 1998.

CRUZ, A.O. Avaliação Pós-Ocupação (APO) dos espaços gerados em habitações autoconstruídas:o caso da favela Nossa Senhora Aparecida em São Miguel Paulista. 1998. Dissertação(mestrado)- Faculdade de Arquitetura e Urbanismo, Universidade de São Paulo. São Paulo, 1998.

ESCOLA POLITÉCNICA DA USP. São Paulo. Diretrizes para apresentação de dissertações e teses. Disponível em: <http://www.poli.usp.br> Acesso em março/03.

ESTADÃO, São Paulo. Dolar - 1996. Disponível em: http:// www.estadão.com.br Acesso em: março/03.

GOLDENBERG, M.A arte de pesquisar: como fazer pesquisa qualitativa em ciências sociais. Rio de Janeiro: Record, 1997.

HABI/6-SUL; HABI/CS - Superintendência de Habitação Popular. Projeto de Urbanização de Favela da Região do Guarapiranga: Favela Comunidade 7 de Setembro. São Paulo: Prefeitura do Município de São Paulo - Secretaria de Habitação e Desenvolvimento Urbano, out. 1992.

HALL, E.T. Dimensão Oculta. 3.ed. Rio de Janeiro: Francisco Alves Editora, 1989.

LAY, M.C.D. Influência de tipos arquitetônicos e grau de acessibilidade na apropriação 
de espaços abertos coletivos em conjunto habitacionais mistos. In: ENCONTRO NACIONAL DE TECNOLOGIA DO AMBIENTE CONSTRUÍDO,8., Salvador, 2000. Anais. Salvador, 2000. p.1519-1526.

LIMA, C.P.C.S.;PELLEGRINO, P.R.M. Aplicação da APO no espaço livre urbano. In: ENCONTRO NACIONAL DE TECNOLOGIA DO AMBIENTE CONSTRUÍDO,5, São Paulo, 1993. Anais. São Paulo: Epusp, 1993. p.885-892.

LYNCH, K. La Imagen de la Ciudad. 3.ed. Espanha: GG Reprints, 1988.

LÜDKE, M.; ANDRÉ, M.E.D.A. Pesquisa em educação: abordagens qualitativas. São Paulo: EPUA, 1986.

MARCUS, C. C. House as a mirror of self: exploring the deeper meaning of home. Berkeley: Conari press, 1997.

MARCUS, C. C.; FRANCIS, C. A.People Places: design guidelines for urban open space. New Yok: Van Nostrand Reinhold, 1990.

MEDVEDOVSKI, N. S. A vida sem condomínio: configuração e serviços públicos urbanos em conjuntos habitacionais de interesse social. 1988. Tese(doutorado)- Faculdade de Arquitetura e Urbanismo, Universidade de São Paulo, 1998.

NEWMAN, O. Defensible space: crime prevention through urban design. New York: Macmillan Publishing, 1973.

ORnSteIN, S.0; ROMERO, M. Avaliação Pós-Ocupação do Ambiente construído. São Paulo: Studio Nobel-Edusp, 1992.

ORNSTEIN, S.0. Avaliacão Pós-Ocupacão: produção nacional e internacional recentes e as tendências rumo do século xxi. In: ENCONTRO NACIONAL DE TECNOLOGIA DO AMBIENTE CONSTRUIDO,5., São Paulo, 1993. Anais. São Paulo: Epusp, 1993. p. $855-1864$.

ORNSTEIN, S.O. Pesquisas sobre ambiente e comportamento em países do primeiro mundo e seus reflexos nos países em desenvolvimento :mais de 20 anos de dialética e in- 
terdisciplinaridade. SEMINARIO NATUREZA E PRIORIDADES DE PESQUISA EM ARQUITETURA E URBANISMO, São Paulo, 1990. Anais. São Paulo: Fauusp-Fupam, 1990. p.35-40.

PEREIRA, P.M.S. Intervenção habitacional em favelas no município de São Paulo através do Projeto Cingapura: o Conjunto Zaki Narchi. Dissertação(mestrado)- Escola Politécnica, Universidade de São Paulo. São Paulo, 2001.

PREFEITURA DE SÃO PAULO. São Paulo. Plano-Diretor. Disponível em: http://portal. prefeitura.sp.gov.br. Acesso em 14/03/03.

PREISER, W.F. E.; RABINOWITZ, H.Z.; WHITE, E.T. Post-Occupancy Evaluation. New Yok: Van Nostrand Reinhold, 1988.

SAMPAIO, M.R.A. Vida na Favela. In: SAMPAIO, M.R.A. et al. Habitação e Cidade. São Paulo: FAU/USP, 1998.

SANTOS, M. et al. Espaço e Qualidade: Avaliação Pós-Ocupação de Projetos de Habitação Popular no Brasil - Conjunto Bento Ribeiro Dantas. In: ENCONTRO NACIONAL DE TECNOLOGIA DO AMBIENTE CONSTRUÍDO, Florianópolis,7., 1998. Anais. Florianópolis, 1998. p.767-774.

Secretaria de Habitação e Desenvolvimento Urbano. Sumário de dados Departamento de Habitação. Prefeitura Municipal de Diadema, 1996.

TABLAS, A .S.; MIGLIORINI, V.L.B.; BENEVENTE, V.A. Avaliação Pós-Ocupação dos espaços de uso público das rua tecnológicas de Ribeirão Preto. In: ENCONTRO NACIONAL DE TECNOLOGIA DO AMBIENTE CONSTRUÍDO,8., Salvador, 2000. Anais. Salvador, 2000. p.1471-1478.

RAPOPORT, A. House form and culture. New Jersey: Prentice-Hall, 1969.

TASCHNER, S.P. Favelas e Cortiços no Brasil: 20 anos de pesquisas e políticas. São Paulo, s.d.

SHIRVANI, H. Beyond public architecture: strategies for design evaluations. New Yok: 
Van Nostrand Reinhold, 1990.

SOMMER, R. Espaco Pessoal:as bases comportamentais de projetos e planejamentos. São Paulo: EPU, 1973.

TASCHNER, S.P. São Paulo: Moradia e o Redesenho da Cidade. In: SAMPAIO, M.R.A. et al. Habitação e Cidade. São Paulo: FAU/USP, 1998.

UGP- Unidade de Gerenciamento do Programa. Programa de Saneamento Ambiental da Bacia do Guarapiranga: Informações Gerais. São Paulo, Projeto Guarapiranga, jul. 1997.

WERNA, E. et al. Pluralismo na habitação. São Paulo: Annablume, 2001.

WEBRASCA DO BRASIL. Bússola. Disponível em: < http://www.apontador.com.br > Acesso em: março/03.

VALLADARES, L. Políticas Alternativas De Habitação Popular: Um Vôo Sobre a Literatura Internacional. In: $9^{\circ}$ ENCONTRO ANUAL DA ANPOCS, Águas de São Pedro, 1985. Anais. Águas de São Pedro,1985. P.1-29.

VERAS, M.P; TASCHNER, S.P. Evolução e Mudanças das Favelas Paulistanas. Revista Espaço e Debates, São Paulo, n.31, p.52-71,1990.

ZIEGLER, S.; ANDREWS, H.F. Children and Built Environments: a review of methods for environmental research and design. In: BECHTEL, R.; MARANS, R.W.; MICHELSON, W. Methods in environmental and behavior research. New York: Van Nostrand Reinhold Company, 1987.

ZIMRING, C.M. bf Evaluation of Designed Enviroments: Methods for Post-Occupancy evaluation. In: BECHTEL, R.; MARANS, R.W.; MICH ELSON, W. Methods in environmental and behavior research. New York: Van Nostrand Reinhold Company, 1987. 


\section{Anexo 1}

\section{Lista de materiais encontrados na}

\section{SEHAB-II}

1. Informações para avaliação Qualitativa e Quantitativa das Favelas do Lote I - Favela 7 de Setembro.( Relatório )

2. Tramites burocráticos referentes a posse de uma área dentro da favela, cuja Cessão está em posse do lar André Luís de Interlagos e EEPG. Helbert Baldus.

3. Documentos sobre vários assuntos tratados durante o decorrer da realização das obras. São referente as responsabilidades de gerenciamento/administrativo entre várias instâncias envolvidas, principalmente prefeitura/estado.

4. Fichas de Atendimento Individual aos moradores.

5. Fichas de Acompanhamento pela assistência social ( pós- inauguração e durante as obras)

6. Relatórios de Visitas técnicas, para o encaminhamento da execução de algumas obras não concluídas pela BETER, em residências ( pós- inauguração).

7. Reportagem publicada no Diário Popular em 04/10/95 ( Seção/coluna - Cidades). "Favela de Guarapiranga passa por urbanização- Sobre a 7 de Setembro.

8. Reportagem publicada no Estado de São Paulo 04/10/95( Seção Cidade e Ambiente) . "Prefeitura urbaniza favela em Guarapiranga". Sobre programa e 7 de Setembro.

9. Convite do secretário Municipal da Habitação e Desenvolvimento Urbano, Lair Alberto Soares Krahenbuhl, para inauguração das obras na Sete de Setembro. 
10. Relação das casas que possuem crianças que utilizaram bonés na inauguração da Favela: Viela do Sossego, Viela 1 e Viela da Paz.

11. Projeto de urbanização de Favelas, apresentado pela Assistência Social, constituído por: apresentação, histórico, objetivos, caracterização da situação física/jurídica e social, Alternativa adotada, treinamento do trabalho social: diretrizes e procedimentos metodológicos.

12. Alguns mapas de localização.

13. Cartas feitas por alguns moradores à assistência social solicitando a resolução de alguns problemas.

14. Cadastro dos Moradores da Viela do Sossego Setor 2 e 3: Nome do proprietário, RG, n( de adultos e crianças, quantidade de cômodos por habitação e n( da habitação.

15. Ata de Reunião e Lista de presença de uma reunião realizada em 03/01/92: "Reunião com a População da comunidade 7 de setembro e representantes da prefeitura."

16. Carta convite para a Participação da Sueli numa reunião na Sehab, cujo assunto é a construção de uma creche junto à favela, pedido solicitado pela entidade.

17. Atas de reunião entre funcionários da PMSP, BETER, Consórcio.

18. Ata de Reunião realizada dia 09/12/93 no SECOVI. Assunto: Retomada do Programa de Recuperação urbana e Projeto Guarapiranga.

19. Ata de Reunião realizada em 10/03/92 com a população dos setores 2 e 3.

20. Lista de Presenças e Ata de Reunião realizada em 28/04/94 no SECOVI. Assunto: Retomada das obras- atendimento a carta de crédito para removidos.

21. Ata de reunião realizada em 22/06/94 no SECOVI. Assunto: Carta de crédito (financiamento) para as moradias que serão removidas por conta do projeto.

22. Carta da BETER se posicionando em relação a construção de habitação.

23. Relocações - Lote I: nomes e endereços.

24. Casos de Xadrez, informativo para a UGP. ( total de 4).

25. Caracterização sócio-econômica das famílias moradoras da Favela Santa Lucia II Estudo de caso: Manual do pesquisador, modelo de questionário aplicado, gráficos com os resultados catalogados. 
26. Cadastramento/Caracterização sócio-econômica das famílias a serem removidas nos lotes I, II e III. ( março/1994).

27. Ajuda memória de Reuniões, reunião realizada em 25/08/93 entre a SEHAB, HABI, CDHU, UGP/COBRAPE. O assunto é a Metodologia do trabalho social.

28. "Proposta de Alternativas do atendimento Habitacional"elaborado pela CDHU e colocada para discussão conjunta com a UGP, CDHU e PMSP.

29. Planta do Projeto de Urbanismo com a demarcação dos lotes onde ocorreram remanejamentos e remoções.

30. Folhas contendo a demarcação das áreas divididas em setores I, II e III. 


\section{Anexo 2}

\section{Lista de materiais encontrados no}

\section{Consórcio JNS-HagaPlan e na}

\section{Construtora BETER}

Neste foram encontrados dados do Programa como um todo ( tem algumas partes referentes especificamente a Sete de Setembro)
A) Consórcio JNS-HagaPlan
1. Relatórios de Atividades Vol. 1 e Vol. II
2. Relatório de Impacto Sobre o Meio Ambiente.
3. Arquivo de mais de 100 fotos referentes ao antes, durante e depois da urbanização.
B) construtora BETER
1. Arquivo de 32 fotos referentes ao antes, durante e depois da reurbanização da favela selecionada. 


\section{Anexo 3}

\section{Lista de materiais encontrados na UGP}

1. Projeto Básico: Planta da Rede de distribuição de Água Fls. 1, 2 e 3.

2. Projeto Básico: Planta do Projeto Geométrico e Pavimentação Fls. 1, 2 e 3.

3. Projeto Básico: Planta de Urbanismo Fls. 1, 2 e 3.

4. Projeto Básico: Planta da Canalização e Drenagem Superficial fls. 1, 2 e 3.

5. Projeto Básico: Planta da Rede Coletora de Esgotos Fls. 1, 2 e 3.

6. Memorial descritivo e Memorial de cálculo - Coleta de Lixo e Acessórios.

7. Especificações Técnicas e forma de Medição e Pagamento.

8. Planta das Favelas do Município de São Paulo - Reurbanização de favelas/ Recuperação urbana.

9. Pasta com 45 fotos demonstrando (antes, durante e depois) da urbanização.

10. São referentes ao Programa como um todo:

11. Folha A4- Limites da bacia/Limites dos municípios/Reservatório Guarapiranga/Hidrografia Principal.

12. Folha A4- Limites da bacia / Hidrografia secundária e Bacia do Guarapiranga.

13. Folha A4- Sistemas de Esgotos.

14. Folha A4- Localização das Favelas.

15. Folha A4- Limites da bacia/Limites dos municípios/Reservatório Guarapiranga/Hidrografia Principal.

16. Informações Gerais sobre o Programa Guarapiranga - julho/1997.

17. Programa de Saneamento ambiental da Bacia do Guarapiranga - Vol. 3 / Organização 
Institucional - out/1991.

18. Programa de Saneamento ambiental da Bacia do Guarapiranga - Vol. 1 / Descrição e Justificativa. Out/1991.

19. Plano de Desenvolvimento e Proteção Ambiental da Bacia do Guarapiranga - Diagnóstico Ambiental Vol. 1 Revisão 2. - janeiro/1997.

20. Plano de Desenvolvimento e Proteção Ambiental da Bacia do Guarapiranga - Diagnóstico Ambiental Vol. 2 Revisão 2. Parte 4 "Principais Temas Ambientais- janeiro/1997. 


\section{Anexo 4}

\section{Questionário Piloto}

\section{COMUNIDADE SETE DE SETEMBRO}

Bloco I - Caracterização da família entrevistada

Nome:

Endereço: $\mathrm{N}^{\circ}$

Ponto de referência:

1. Há quanto tempo vive em São Paulo?

2. Há quanto tempo mora na Comunidade 7 de Setembro ?

3. Como adquiriu a sua habitação:

4. Caso não seja proprietário, qual é a sua condição nesta habitação?

5. Morava no bairro quando foram realizadas as obras de urbanização na comunidade sete de setembro?

( ) $\operatorname{sim} \quad$ ( ) não

6. Qual a sua idade:____anos; Gênero: ( ) masculino ( ) feminino ; Estado civil: ( ) Sol. ( ) Casado.

7. Qual é sua ocupação?

8. Renda familiar aproximada:
( ) até 1 Sal. Min.
( ) de 1 a 3 Sal. Min.
( ) de 3 a 5 Sal. Min.
( ) de 5 a 7 Sal. Min.
( ) de 7 a 9 Sal. Min.
( ) de 10 ou mais Sal. Min.

9. Escolaridade
A. Analfabeto ( )
B. $1^{\circ}$ Grau Incompleto ( )
C. $1^{\circ}$ Grau Completo ( )
D. $2^{\circ}$ Grau Incompleto ( )
E. $2^{\circ}$ Grau Completo ( )
F. $3^{\circ}$ Grau Incompleto ( )
G. $3^{\circ}$ Grau Completo ( )

10. Caracterização do grupo familiar.

- Quantas pessoas compõem a sua família (contando com você) 


\begin{tabular}{|c|c|c|c|c|c|c|c|c|c|c|c|c|c|c|c|c|}
\hline \multirow{4}{*}{ Nome } & \multirow{4}{*}{ Posição } & \multicolumn{3}{|c|}{ Naturalidade } & \multirow{2}{*}{\multicolumn{2}{|c|}{ Sexo }} & \multirow{3}{*}{ Idade } & \multirow{2}{*}{\multicolumn{7}{|c|}{ Estuda }} & \multirow{2}{*}{\multicolumn{2}{|c|}{ Trabalha }} \\
\hline & & \multirow{2}{*}{ Estado } & \multicolumn{2}{|c|}{ Zona } & & & & & & & & & & & & \\
\hline & & & rural & urbana & & & & & & & & & & & & \\
\hline & & & & & $\mathrm{m}$ & $\mathrm{f}$ & & $\mathrm{a}$ & b & $\mathrm{c}$ & d & $\mathrm{e}$ & f & $\mathrm{g}$ & Sim & Não \\
\hline & chefe & & & & & & & & & & & & & & & \\
\hline & & & & & & & & & & & & & & & & \\
\hline & & & & & & & & & & & & & & & & \\
\hline & & & & & & & & & & & & & & & & \\
\hline & & & & & & & & & & & & & & & & \\
\hline & & & & & & & & & & & & & & & & \\
\hline
\end{tabular}

11. Antes de morar aqui na 7 de Setembro, em que tipo de moradia vivia:

\begin{tabular}{|c|c|c|c|c|}
\hline $\begin{array}{c}\text { Tipos de } \\
\text { moradia }\end{array}$ & \multicolumn{3}{|c|}{ LOCAL } \\
\hline Favela & $\begin{array}{c}\text { Município de } \\
\text { São Paulo }\end{array}$ & $\begin{array}{c}\text { Outro município da } \\
\text { Grande São Paulo }\end{array}$ & $\begin{array}{c}\text { Interior do Estado } \\
\text { de São Paulo }\end{array}$ & $\begin{array}{c}\text { Outro Estado } \\
\text { ou País }\end{array}$ \\
\hline $\begin{array}{c}\text { Habitação } \\
\text { coletiva / } \\
\text { Cortiço }\end{array}$ & & & & \\
\hline $\begin{array}{c}\text { Casa ou } \\
\text { Apartamento } \\
\text { Alugado }\end{array}$ & & & & \\
\hline $\begin{array}{c}\text { Casa ou } \\
\text { Apartamento } \\
\text { Próprio }\end{array}$ & & & & \\
\hline Casa de & & & & \\
Parente & & & & \\
( não favela) & & & & \\
\hline Outro: & & & & \\
\hline
\end{tabular}

12. Quantas pessoas viviam em seu domicílio na época da urbanização ?

13. Quantas pessoas vivem atualmente no seu domicílio?

13.1Qual a condição, caso exista das novas pessoas que residem em seu domicílio:
( ) parente
( ) inquilino
( ) extensão familiar 
Bloco II. Levantamento da participação da população enquanto organização comunitária

1. Você participava da Associação Comunitária antes das melhorias no bairro?

( ) Não

( ) $\operatorname{Sim}$

( ) Não sabe

( ) Não respondeu

2. Você começou a atuar na Associação Comunitária após a execução de melhorias no bairro?

( ) Não

( ) $\operatorname{Sim}$

( ) Não sabe

( ) Não respondeu

3. Depois da implementação das melhorias na área você acha que a atuação da Associação comunitária:

( ) Melhorou

( ) Piorou

( ) Não houve alteração

( ) Não sabe

( ) Não respondeu

4. Você acha que é importante a participação comunitária para que se conseguir melhorias no bairro?

( ) Não

( ) $\mathrm{Sim}$

( ) Não sabe

( ) Não respondeu

5. Quem você reconhece como liderança (líder) comunitária na sua comunidade?

Bloco III. Nível de satisfação dos moradores após a Urbanização

1. Depois da urbanização a vida na comunidade:

( ) Melhorou

( ) Piorou

( ) Não houve alteração

( ) Não sabe

( ) Não respondeu

1.1 Cite pelo menos quatro motivos, que justifiquem a sua resposta.

1)

2)

3)

4)

2. Qual a mudança mais importante que foi feita? Justifique 
3. O que ainda precisa mudar no bairro?

4. A sua vida familiar melhorou?

( ) Melhorou

( ) Piorou

( ) Não houve alteração

( ) Não sabe

( ) Não respondeu

4.1 O que melhorou ou piorou? Justifique

5. O número de pessoas que freqüentam a escola em sua família aumentou após urbanizar?
( ) $\mathrm{Sim}$
( ) Não
( ) Não houve alteração
( ) Não sabe
( ) Não respondeu

6. O número de assaltos diminuiu após urbanizar?

( ) $\operatorname{Sim}$

( ) Não

( ) permaneceu a mesma coisa

( ) Não sabe

( ) Não respondeu

7. Adquiriu mais eletrodomésticos?

( ) $\mathrm{Sim}$

( ) Não

( ) Não houve alteração

( ) Não sabe

( ) Não respondeu

8. Cite pelo menos 4 pontos que você ache positivo e negativos após a urbanização:

\begin{tabular}{|l|l|}
\hline \multicolumn{1}{|c|}{ Pontos Favoráveis } & \multicolumn{1}{c|}{ Pontos Desfavoráveis } \\
\hline 1. & 1. \\
\hline 2. & 2. \\
\hline 3. & 3. \\
\hline 4. & 4. \\
\hline
\end{tabular}

9. O que acha das vielas realizadas no interior da favela?

( ) ótimo

( ) Bom

( ) Regular 
( ) Precária

10. Justifique sua resposta:

11. Você fez alguma reforma, ampliação ou acabamento em sua casa após a urbanização? Qual (is)?

\begin{tabular}{|l|l|l|}
\hline & Sim & não \\
\hline Área externa & & \\
\hline Construiu muro & & \\
\hline Construiu garagem & & \\
\hline Construiu lavanderia & & \\
\hline Construiu varanda & & \\
\hline Revestiu paredes & & \\
\hline Revestiu piso & & \\
\hline Construiu outros cômodos & & \\
\hline Pintou & & \\
\hline Trocou janelas & & \\
\hline Trocou portas & & \\
\hline & & \\
\hline Área Interna & & \\
\hline Revestiu paredes & & \\
\hline Pintou cômodos & & \\
\hline Dividiu cômodos existentes & & \\
\hline Trocou portas & & \\
\hline Ampliou cômodos & & \\
\hline Elétrica & & \\
\hline Hidráulica & & \\
\hline Esgoto & & \\
\hline
\end{tabular}

12. Em relação a comunidade Sete de Setembro, avalie:

\begin{tabular}{|c|c|c|c|c|c|}
\hline & 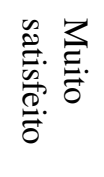 & 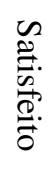 & 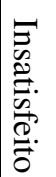 & 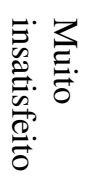 & 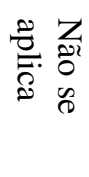 \\
\hline \multicolumn{6}{|l|}{ 1.Serviço de Limpeza urbana } \\
\hline \multicolumn{6}{|l|}{ 2.Conservação das áreas verdes e calçadas } \\
\hline \multicolumn{6}{|l|}{ 3. Instalações Públicas (orelhão, caixa de correios, bancos) } \\
\hline \multicolumn{6}{|l|}{ 4. Acesso aos meios de transportes (ônibus, taxi, lotação) } \\
\hline \multicolumn{6}{|l|}{$\begin{array}{l}\text { 5. Iluminação nas Vias de circulação na vias } \\
\text { 6. Iluminacão nas vielas }\end{array}$} \\
\hline \multirow{2}{*}{\multicolumn{6}{|c|}{$\begin{array}{l}\text { 6. Iluminação nas vielas } \\
\text { 7.Local para as atividades esportivas ( voley, futebol, etc..) }\end{array}$}} \\
\hline & & & & & \\
\hline \multicolumn{6}{|l|}{ 8. Acesso dos jovens às escolas } \\
\hline \multicolumn{6}{|l|}{ 9. Fácil estacionamento } \\
\hline \multicolumn{6}{|c|}{ 10. Segurança na Comunidade, crianças podem brincar na rua } \\
\hline \multicolumn{6}{|c|}{ 11. Convivência social entre jovens (crianças e adolescentes) } \\
\hline \multicolumn{6}{|l|}{ 12. Convivência social entre adultos } \\
\hline \multicolumn{6}{|l|}{ 13. Existência de árvores } \\
\hline \multicolumn{6}{|l|}{ 14. Utilização das áreas verdes pelos moradores } \\
\hline \multicolumn{6}{|l|}{ 15. Participação no cuidado das áreas verdes } \\
\hline $\begin{array}{l}\text { 16.Contato com os moradores de outras comunidades } \\
\text { circunvizinhas }\end{array}$ & & & & & \\
\hline
\end{tabular}


13. Você se sente como responsável pela gestão/ manutenção das modificações executadas na comunidade?
( ) Não
( ) $\operatorname{Sim}$
( ) Não sabe
( ) Não respondeu

14. Você venderia sua casa?

( ) Não

( ) Sim, se dessem um bom preço

( ) Sim, se precisasse mudar daqui

( ) Não sabe

( ) Não respondeu

15. Você alugaria sua casa?

( ) Não

( ) Sim, se dessem um bom preço

( ) Sim, se precisasse mudar daqui

( ) Não sabe

( ) Não respondeu

16. O que você acha o aspecto visual após a urbanização?

( ) Ótimo

( ) Bom

( ) Indiferente

( ) Ruim

O que você achou do projeto reboco, comente? 


\section{Anexo 5}

\section{Roteiro para coleta de informações}

\section{junto às instituições}

Educação : creches, centro de juventude, educação infantil ( pré-escola) e educação de primeiro grau

1. Creche

- Endereço

- Quantidade

- Distância em relação a favela (a pé quanto tempo leva ?)

- Faixa etária de atendimento

- Faixa de renda de atendimento

- Tipo de Administração (Direta, indireta, particular conveniada, particular, ?)

- Número de usuários

2. Centros de Juventude

- Endereço

- Quantidade

- Distância em relação a comunidade (a pé quanto tempo leva ?)

- Faixa etária de atendimento (normalmente de 7 a 14 anos)

- Faixa de renda de atendimento

- Tipo de Administração

- Atividades desenvolvidas

- Número de usuários

3. Educação Infantil (pré-escola)

- Endereço 
- Quantidade

- Distância em relação a comunidade(a pé quanto tempo leva ?)

- Faixa etária de atendimento

- Tipo de Administração (pública / particular)

- Número de usuários

4. Educação de primeiro grau

- Endereço

- Quantidade

- Distância em relação a comunidade(a pé quanto tempo leva ?)

- Faixa etária de atendimento

- Tipo de Administração (rede pública / particular)

- Número de usuários

- Número de usuários

Lazer

1. Equipamentos de esporte e cultura

- Esporte (Quantidade e área): Campos de futebol / Centros desportivos municipais / ?

- Cultura (Quantidade): biblioteca / casas de cultura / etc.

2. Áreas de lazer

- Quantidade de: Parques / Praças / Canteiros / Áreas verdes / etc.

Abastecimento

1. Equipamentos públicos: mercados / sacolão / mini-mercado / feiras

Saúde

1. Quantidade de equipamentos existentes:

2. Nível de atendimento ? Primário ( ) secundário ( )

3. Qual a rede ? municipal / estadual / federal

4. Explo: UBS / CS / PAM (primário)

5. Hospitais municipais (secundária)

Infra-estrutura

1. Redes de água e esgoto 
1. Outros elementos a serem observados

- Telefones públicos: quantidade e localização / Rede privada: abrangências

- Comércio: tipo, localização e quantidade

- Transporte coletivo: quantidade de linhas / percurso

- Pontos de ônibus: localização e quantidade existente no entorno da área em estudo

- Entrega de equipamento domésticos

- Coleta e remoção de lixo: responsabilidade e freqüência

- Limpeza de exteriores: responsabilidade e freqüência

- Iluminação pública: estado

- Segurança pública: freqüência de viaturas, policiais

- Delegacia ou posto policial: quantidade e localização

- Correio, caixas de correio: quantidade e localização 
Anexo 6

Planta da Comunidade Sete de

Setembro 


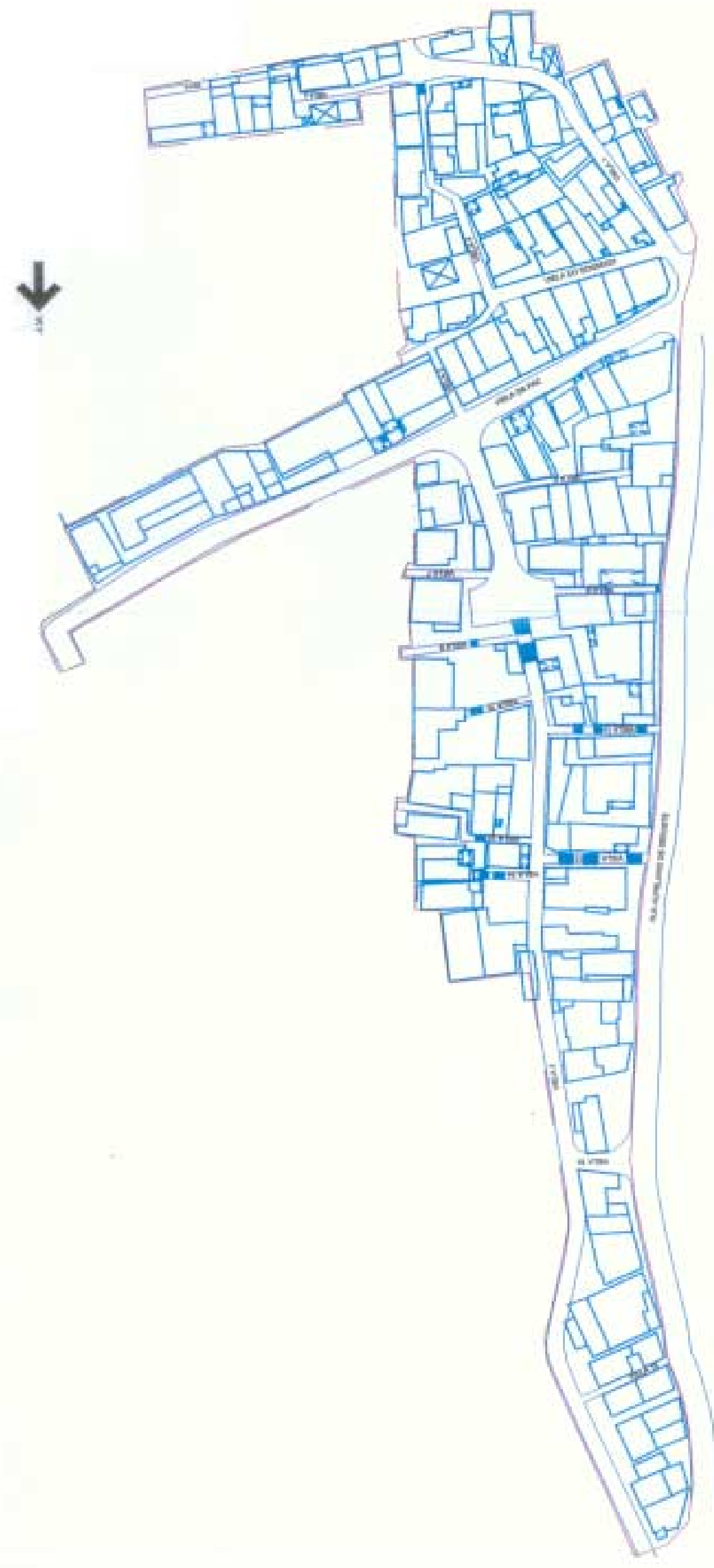




\section{Anexo 7}

Planta com nomenclatura das ruas,

fechamento das vielas, porcentagem de obstrução das grelhas e localização dos telefones públicos 


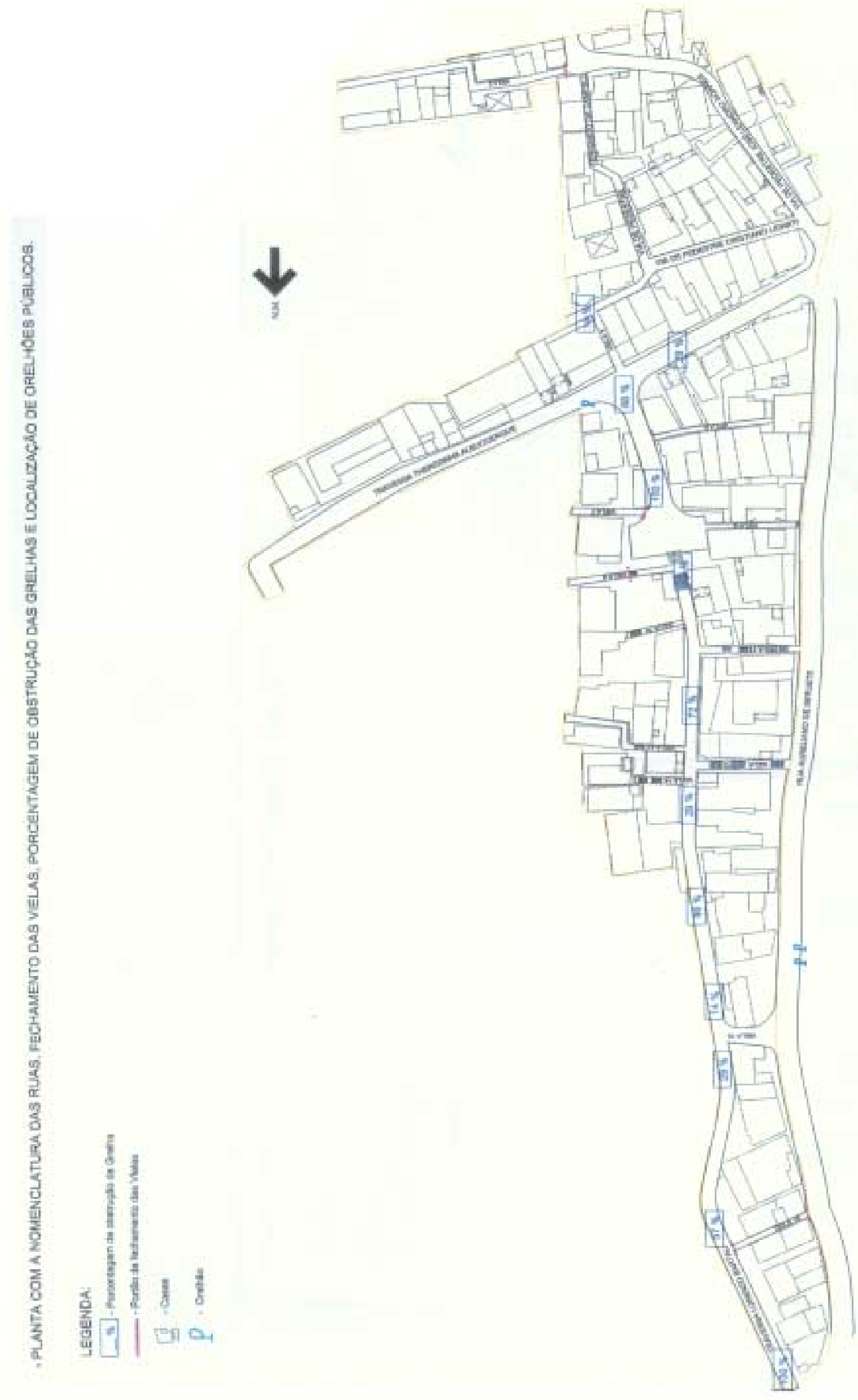




\section{Anexo 8}

Mapeamento das áreas verdes, lixeiras, árvores e pontos de acúmulo de lixo 


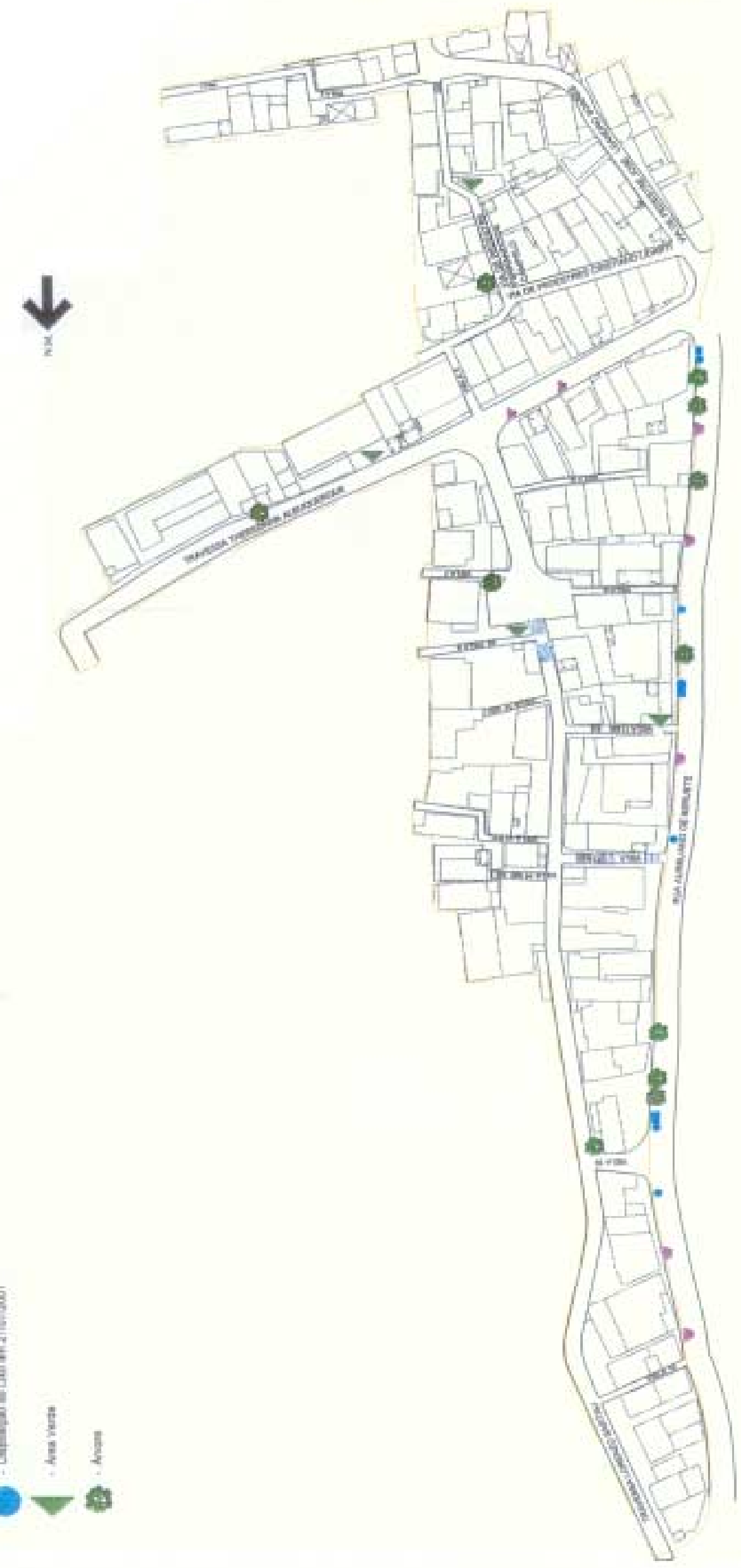


Anexo 9

Mapeamento das atividades realizadas nos espaços públicos (19.07.2001) 


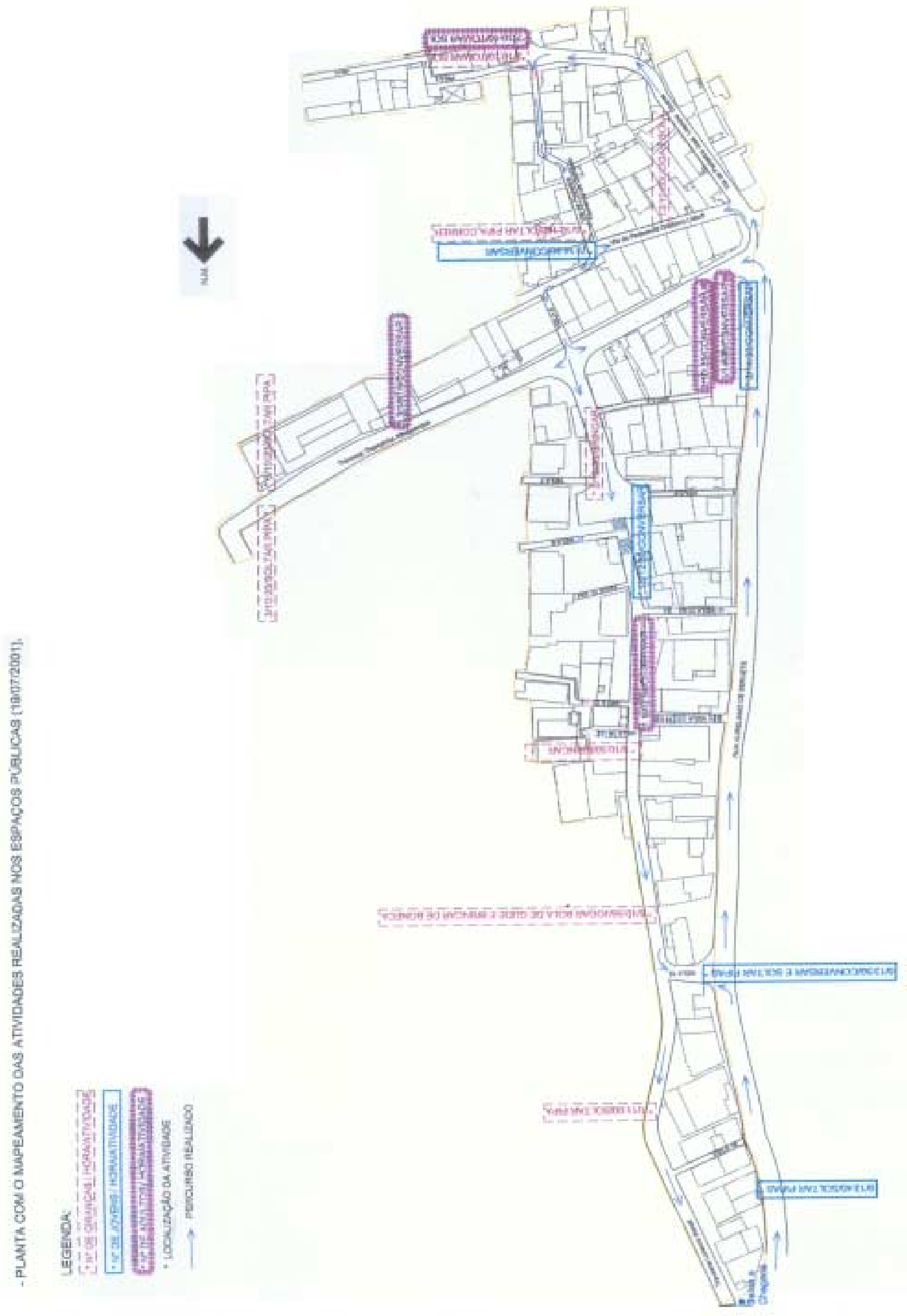


Anexo 10

Mapeamento das atividades realizadas nos espaços públicos (21.07.2001) 


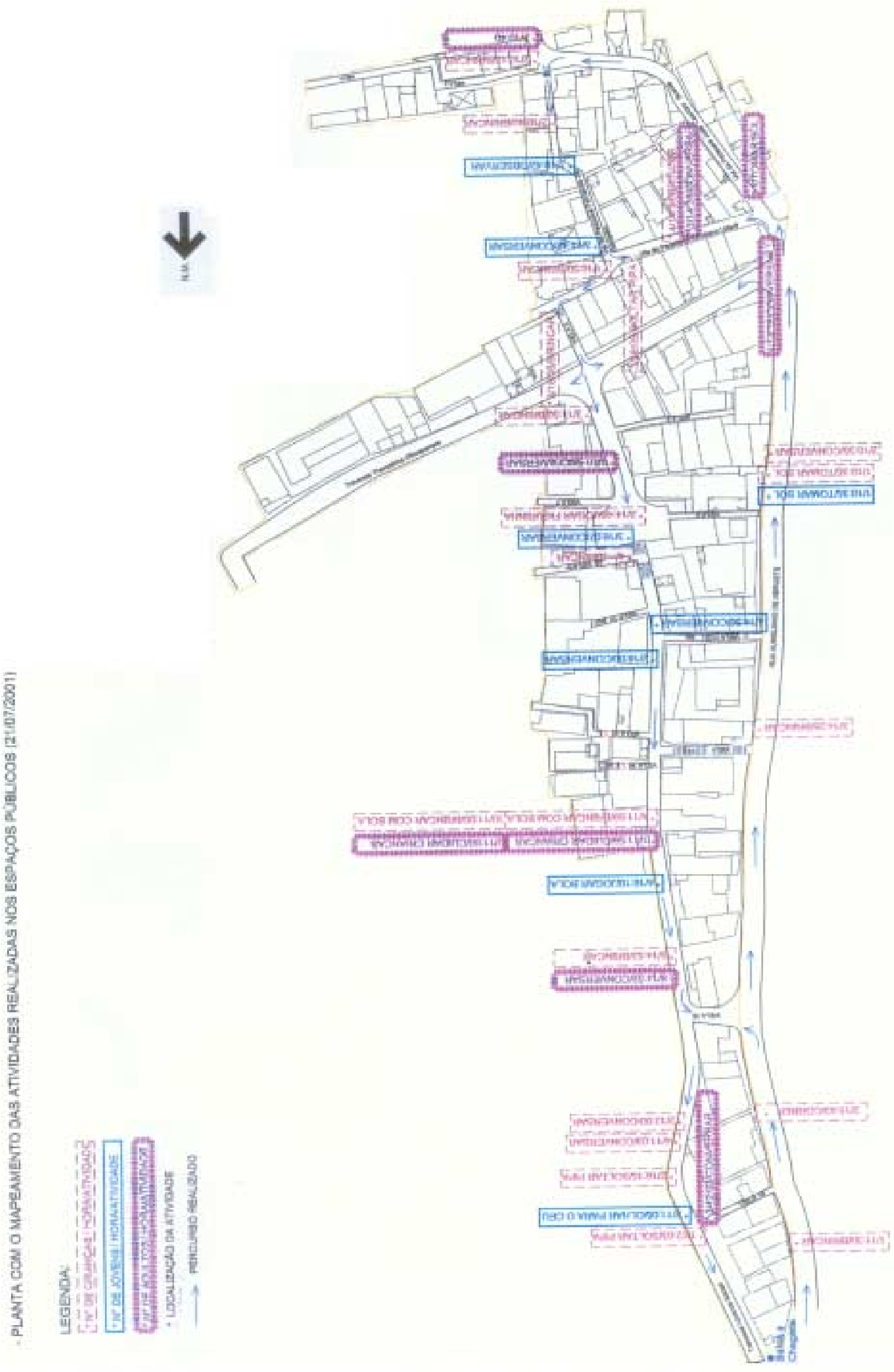




\section{Anexo 11}

\section{Composição do Conselho Consultivo}

\section{Representantes do estado (14)}

Secretarias: Recursos Hídricos, Saneamento e Obras, Meio Ambiente, Habitação, Planejamento e Gestão, Transportes Metropolitanos, Saúde e da Fazenda.

Empresas: SABESP, CDHU, ELETROPAULO, DAEE, EMPLASA e CETESB.

\section{Representantes dos Municípios (14)}

De São Paulo (8 ): Prefeito, Secretário da Habitação, do Planejamento, de Desenvolvimento Urbano, do Verde e Meio Ambiente e das Administrações Regionais, Administrações Regionais da Capela do Socorro e do Campo Limpo.

De Embu (2) e de Embu-Guaçu (2) : Prefeitos e Secretários de Planejamento ou de Infraestrutura ou de Saúde.

De Itapecerica da Serra (2) : Prefeito e Secretário de Planejamento ou de Infra-estrutura ou de Saúde.

\section{Representantes da Sociedade Civil (14)}

Usuários: Imobiliário, Comércio, Indústria, Lazer-Clubes, Moradores - SP, Moradoresoutros municípios.

Associações Técnicas Profissionais: ABES, IAB, Instituto de Engenharia.

Universidades: OSEC, USP.

Ambientalistas: da bacia e da Região metropolitana de São Paulo.

Procuradoria Geral da Justiça. 


\section{Anexo 12}

\section{Roteiro semi-estruturado para}

entrevista coletiva com jovens com

\section{base no questionário piloto e}

observações feitas durante a pesquisa Comunidade Sete de Setembro

Data: 29/06/2002.

Horário: inicial término:

Idade: anos. Sexo:

Você estuda? Sim ( ) Não ( ) Até que série você estudou?

Profissão:

Estado Civil: ( ) casado(a) / ( ) solteira(a) /( ) outros

Você estuda? Sim ( ) Não ( ) Até que série você estudou?

Local de nascimento:

(Se natural de outra cidade) Há quanto tempo vive em São Paulo?

Há quanto tempo mora na Comunidade 7 de Setembro?

Endereço: $n^{\circ}$

Ponto de referência: 
Sua casa é alugada? Sim ( ) Não ( ) não sabe ( )

Depois das obras foi feito alguma mudança na construção da sua casa? O quê?

Quantas pessoas mora (vam) na sua casa quando?

Antes das obras?

Depois das obras?

Se aumentou quem são essas pessoas? (o grau de parentesco?)

Você participa ( va ) da comunidade? Como?

Antes das obras:

Depois das obras:

Quem trabalha na sua casa? (grau de parentesco)

Opcional: Somando os salários de quem trabalha na sua casa, quanto sua família ganha por mês?

\section{Relembrando o passado}

\begin{tabular}{|c|c|}
\hline $\begin{array}{c}\text { O que você mais gostava antes da } \\
\text { urbanização? }\end{array}$ & $\begin{array}{c}\text { O que você não gostava antes da } \\
\text { urbanização? }\end{array}$ \\
\hline & \\
& \\
\hline
\end{tabular}

Referências: (ruas / esgoto / iluminação / diversão / ir p/ escola / doenças? / lixo? / áreas verdes? Comprar? Transporte?). Obs. Marcar X em itens que forem perguntados 


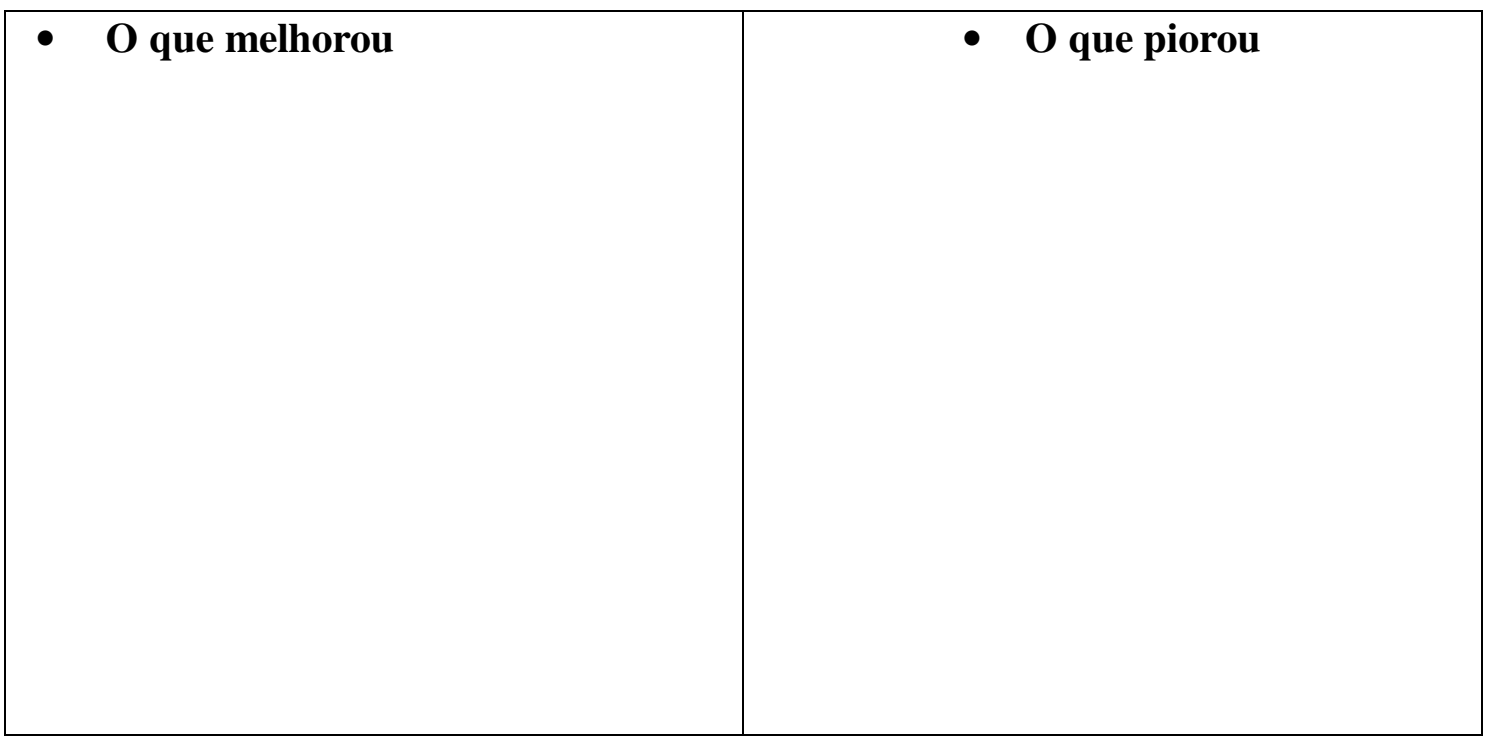

Referências: (ruas / esgotos / iluminação / diversão / ir p/ escola / doenças? / lixo? / áreas verdes? Comprar? Transporte?). Obs. Marcar X em itens que forem perguntados Observações: 


\title{
Anexo 13
}

\section{Roteiro semi-estruturado para}

entrevista coletiva com adultos com

\author{
base no questionário piloto e
}

observações feitas durante a pesquisa -

Comunidade Sete de Setembro

Horário: inicial

Data: 29/06/2002. término:

Idade: anos.

Sexo:

Você estuda? Sim ( ) Não ( ) Até que série você estudou?

Profissão:

Estado Civil: ( ) casado(a) / ( ) solteira(a) /( ) outros

Você estuda? Sim ( ) Não ( ) Até que série você estudou?

Local de nascimento:

(Se natural de outra cidade) Há quanto tempo vive em São Paulo?

Há quanto tempo mora na Comunidade 7 de Setembro?

Endereço: $n^{\circ}$

Ponto de referência: 
Sua casa é alugada ? Sim ( ) Não ( ) não sabe ( )

Depois das obras foi feito alguma mudança na construção da sua casa ? O quê ?

Quantas pessoas mora (vam ) na sua casa quando ?

Antes das obras ?

Depois das obras?

Se aumentou quem são essas pessoas ? ( o grau de parentesco?)

Você participa ( va ) da comunidade? Como?

Antes das obras:

Depois das obras:

Quem trabalha na sua casa ? (grau de parentesco)

Opcional: Somando os salários de quem trabalha na sua casa, quanto sua família ganha por mês?

Relembrando o passado

\begin{tabular}{|c|c|}
\hline $\begin{array}{c}\text { O que você mais gostava antes da } \\
\text { urbanização? }\end{array}$ & $\begin{array}{c}\text { O que você não gostava antes da } \\
\text { urbanização? }\end{array}$ \\
\hline & \\
& \\
& \\
\hline
\end{tabular}

Referências: ( ruas / esgoto / iluminação / diversão / ir p/ escola / doenças ?/ lixo ?/ áreas verdes? Comprar? transporte ?). Obs. Marcar X em itens que forem perguntados 


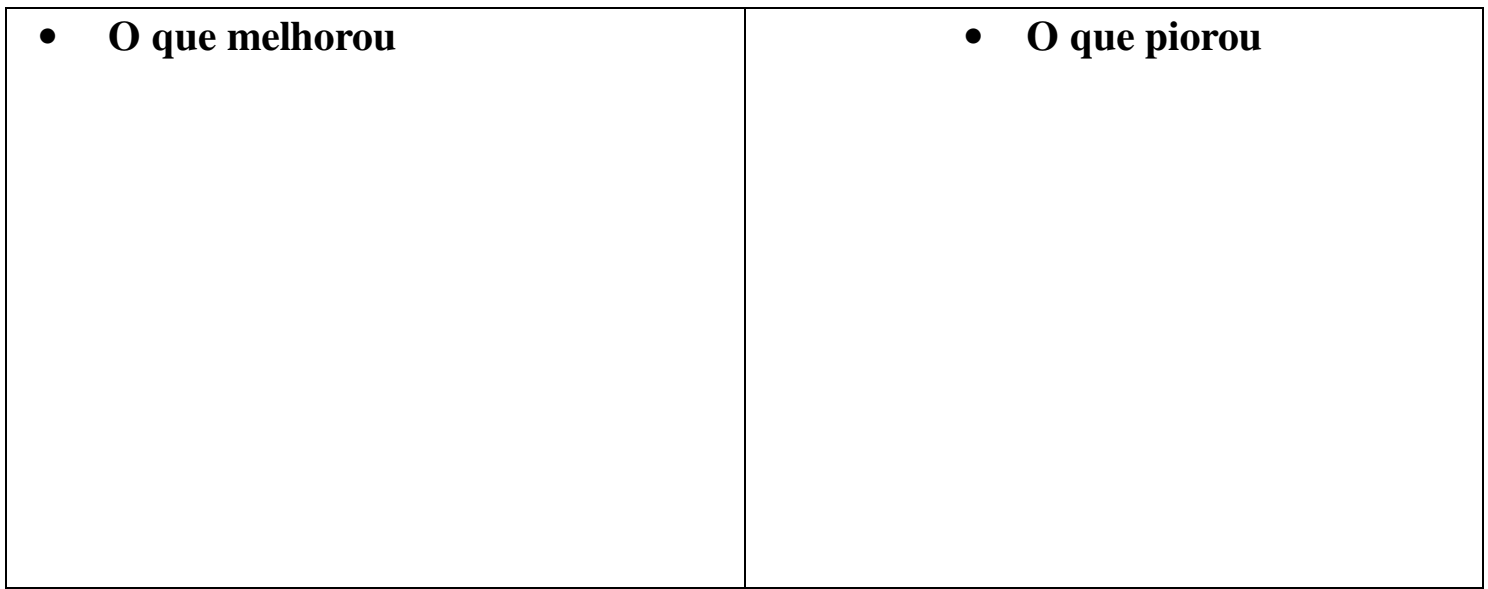

Referências: ( ruas / esgotos / iluminação / diversão / ir p/ escola / doenças ?/ lixo ?/ áreas verdes? Comprar? transporte ?). Obs. Marcar X em itens que forem perguntados

Observações: 
Anexo 14

Fotos da Comunidade antes e depois da urbanização 

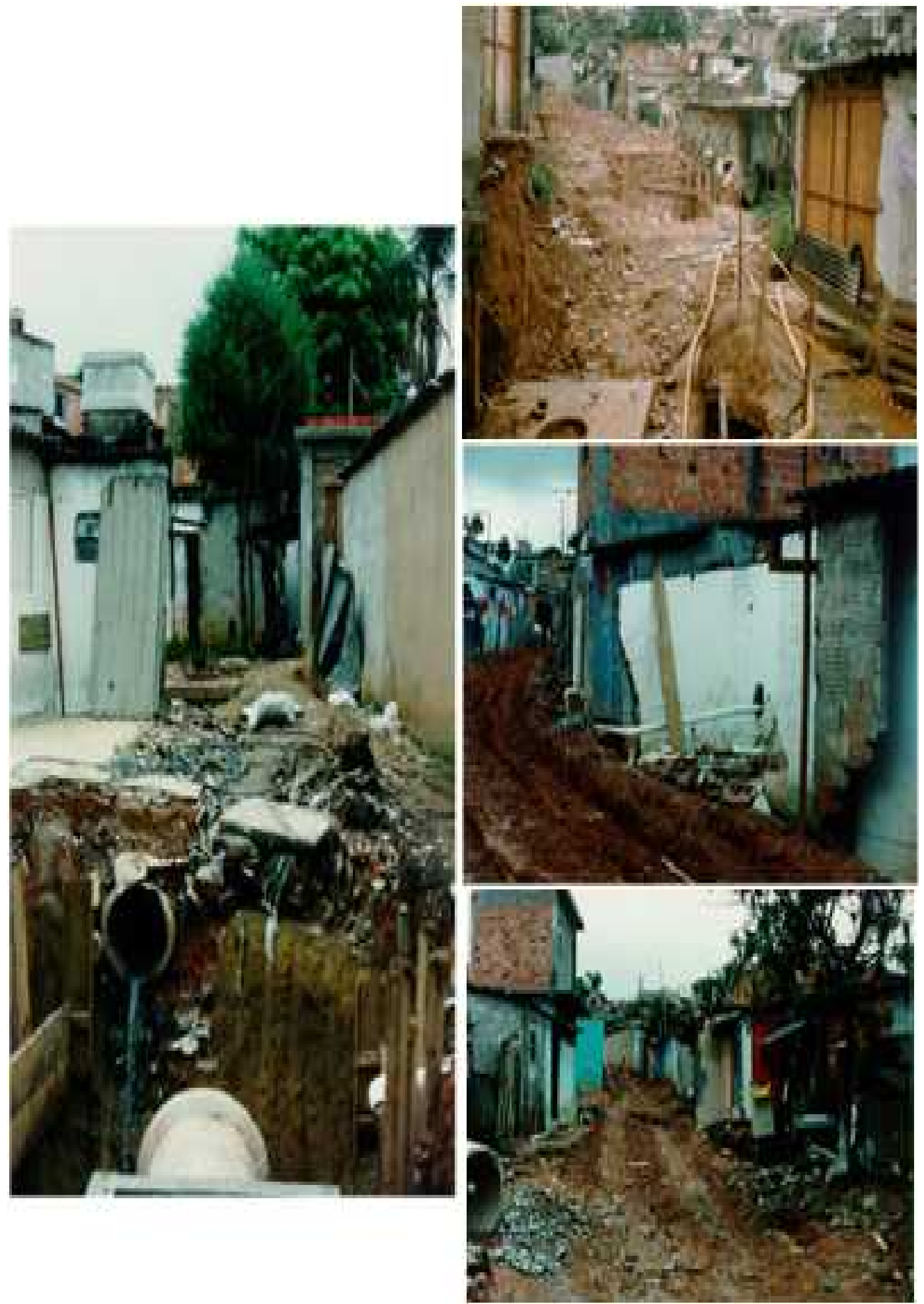

Figura 6.6: Fotos antes da urbanização 

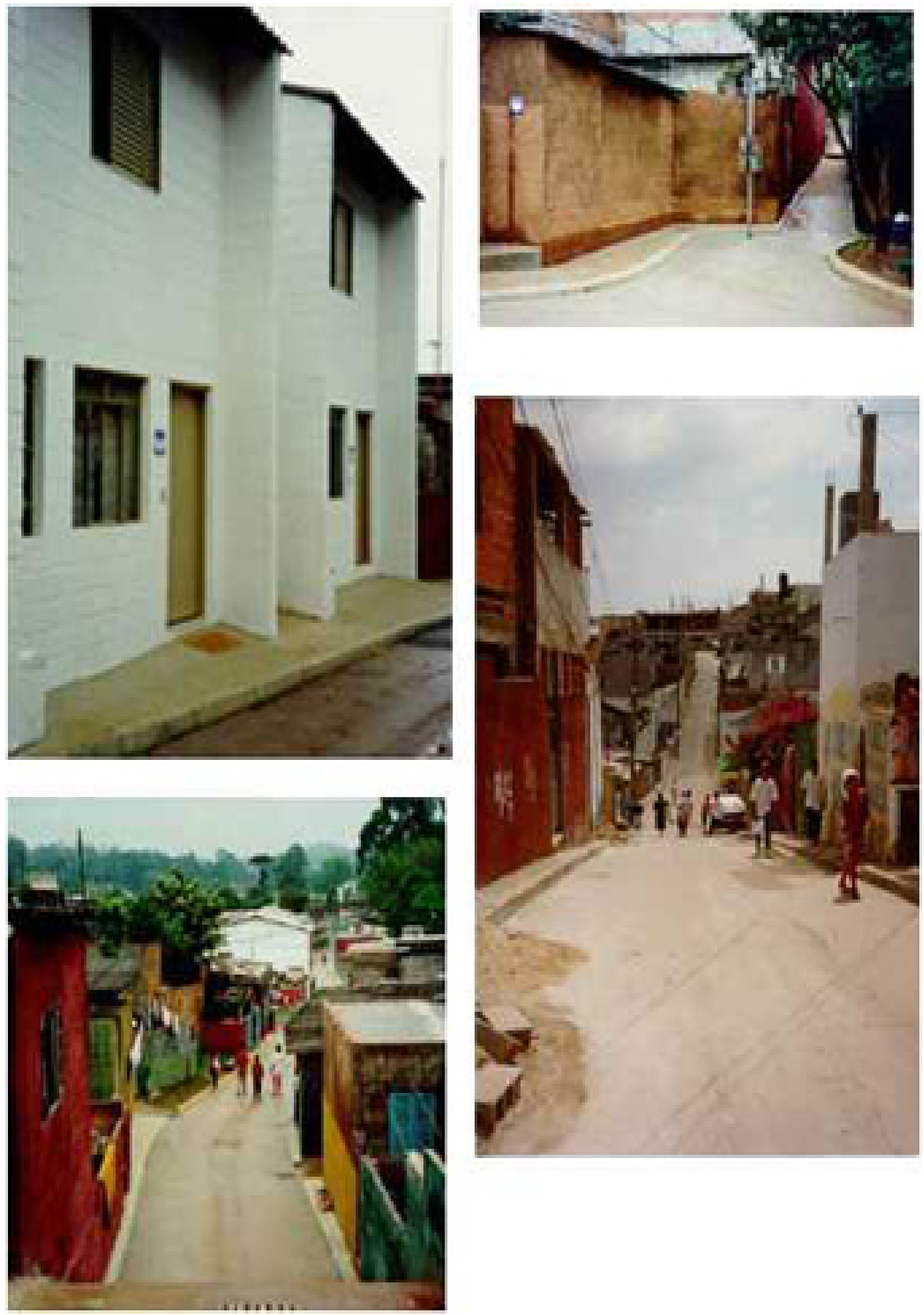

Figura 6.7: Fotos após a urbanização 


\section{Anexo 15}

\section{Lista dos equipamentos Sociais e}

\section{Urbanos que atendem a população da}

\section{Comunidade Sete de Setembro}

\section{Educação}

Existem duas, a Creche Municipal Vereador José Adriano Marrey Júnior e a Jardim Reimberg. Ambas têm administração direta pela prefeitura e atendem um total de 168 crianças, sendo de cerca de 500 vagas a demanda anual não atendida, demanda que se refere a uma das creches, pois a outra não possui tal dado.

Pré-escola o EMEI Aurélio Buarque de Holanda Ferreira, cujo número de usuários gira em torno de 632 alunos, deixa de atender entre 400 a 600 crianças. A Igreja Jardim São Bernardo atende 120 alunos e deixa de atender 80 crianças anualmente. A Igreja Santa Francisca Cabrini atende 120 alunos e não tem dados quanto à demanda não atendida.

Escolas de Primeiro e Segundo Graus foram encontradas 4 instituições do Estado responsáveis pelo ensino de primeiro e segundo graus na região, computando um total de 13.362 usuários. Tais escolas não dispunham de dados referentes à demanda não atendida anualmente. Essas escolas são Hebert Baldus, Afrânio de Oliveira, Palmares II e Ester Garcia. Cursos Profissionalizantes realizados no Secovi (Associação Paulista Projeto Ampliar) atendem jovens da faixa etária de 12 a 17 anos, que participam de cursos de serigrafia, 
datilografia, corte-costura, panificação e confeitaria. A creche André Luiz participa do Programa Agente Jovem que oferece cursos de cidadania, meio ambiente etc. Tais jovens recebem mensalmente ajuda financeira de $\mathrm{R} \$ 65,00$.

A educação para adultos é oferecida na Igreja Jardim São Bernardo e atende anualmente 120 alunos da $1 \mathrm{a}$ à $4 \mathrm{a}$ séries.

Supletivo as escolas mais próximas são no Grajaú ou no Jardim Icaraí.

Projetos, Projeto Crescer, desenvolvido nas Igrejas Santa Francisca Cabrini e Jardim São Bernardo, atende 158 alunos que desenvolvem atividades de leitura, artes, jogos etc. Nenhuma das igrejas consegue atender toda a demanda existente inicialmente.

\section{Equipamentos de esporte e cultura}

- Esporte: Caminhando cerca de 30 minutos da Comunidade Sete de Setembro, encontrase o Centro Desportivo Municipal Jardim Petronita, com campo de futebol, quadra, lanchonete desativada e banheiros.

No Jardim Reimberg há um campo de futebol, e na Vila Natal está a Praça Frei Damião, com 2 quadras, bancos para descanso, 1 palco para apresentações, arquibancadas, mesas para jogos e parque para crianças.

- Cultura: Nas escolas há bibliotecas cujo acesso é restrito aos alunos, que não podem retirar os livros. Na igreja Jardim São Bernardo existe uma única biblioteca aberta à comunidade para consulta, mas não é permitida a retirada de livro do acervo.

\section{Abastecimento e Bancos}

Durante a semana, há feira-livre em dois dias.

Há comércio local, constituído de aproximadamente 87 estabelecimentos: restaurante, farmácia, quitanda, açougue, supermercado, lojinha de produtos diversos, posto de gasolina, igrejas, padaria, banca de jornal, doceria, cabeleireiro, veterinário, lojas de roupas, papelaria, pizzaria, mecânica, auto-escola, adega, bar, academia de ginástica, lava-rápido, locadora, dentistas, loja de móveis, imobiliária, fotográfica, avícola, bicicletaria, loja de 
água mineral, eletrônica, perfumaria, ótica/relojoaria, casa do norte, loja de calçados, loja de produtos de limpeza, sapataria, bijuterias, casa de embalagens, chaveiro, loja de temperos, loja de $\mathrm{CD}$, casa de rações, loja de artesanatos, agência de turismo, floricultura, auto-elétrico, loja de materiais elétricos, loja de tintas, reforma de sofás, loja de cortinas, borracharia, fábrica de pães, loja de artigos para festas infantis, loja de "1 real".

No interior da favela existem três pontos comerciais: 01 doceria situada na Travessa Therezinha Albuquerque, 1 bar situado na Travessa Lorenzo Bartali, 01 bar que é freqüentado por adultos e velhos aposentados, este se encontra na esquina da Travessa Therezinha Albuquerque com a Aureliano de Beruete.

Saúde

Há um posto de saúde da rede municipal no bairro vizinho, no Jardim São José, cuja caminhada até o local leva 30 minutos. O atendimento secundário da região é feito no Grajaú, no Hospital da Universidade OSEC.

\section{Equipamentos e Serviços Públicos}

\section{-Telefones públicos}

Há instalados em toda a favela 3 telefones públicos, sendo que 2 estão situados na Rua Aureliano de Beruete e 1 na Travessa Therezinha Albuquerque. Segundo moradores, a rede privada atende a maior parte das habitações.

\section{Transporte coletivo}

\section{- Ônibus coletivo legalizado}

Linha 6031 - Terminal Santo Amaro / Jardim São Bernardo

Linha 6082 - Santo Amaro / Jardim São Bernardo

Linha - Jabaquara / Vila Natal

Linha - Vila Mariana / Vila Natal

Linha - Conjunto Residencial Palmares

\section{- Ônibus coletivo clandestino}


Linha - Butantã / Jardim das Pedras

\section{- Vans legalizadas}

Jardim São Bernardo / Santo Amaro

Vila Natal / Santo Amaro

\section{- Vans não legalizadas}

Jardim São Bernardo / Santo Amaro

Vila Natal / Santo Amaro

\section{- Pontos de ônibus}

Existem pontos próximos à comunidade, principalmente onde se encontra estabelecida a grande parte do comércio. Nesta região concentram-se os pontos finais de algumas das linhas de transporte descritas acima.

\section{Limpeza}

O lixeiro recolhe duas vezes por semana o lixo e passa pela travessa Therezinha de Albuquerque e na rua Aureliano de Beruete. Os moradores que não têm suas moradias de frente para essas vias levam os seus sacos de lixo e depositam nas esquinas das vielas.

A limpeza de exteriores e vias de circulação é executada pelos próprios moradores.

\section{Segurança pública}

A Delegacia, $83^{\circ} \mathrm{DP}$, situada no Jardim Minas, atende a região. Segundo informações dos moradores, não há policiamento freqüente, e quando a viatura é solicitada existe demora no atendimento. Durante as diversas vezes em que a pesquisadora esteve na área, não foi vista nenhuma viatura policial em ronda.

\section{Correios}

Segundo relatos de moradores a Eletropaulo, atualmente não vem fazendo a entrega das contas nas residência deles sendo esses, obrigados a retirá-la na Agência mais próxima ( situada no Parque das Árvores ), o percurso leva até 01 h30 a pé. Existe uma caixa de correio junto a área comercial próxima à favela onde as pessoas podem depositar suas 
correspondências, no entanto, para recebimento das mesmas constatamos que apesar dos moradores da comunidade terem endereço, em alguns locais a entrega das correspondências está sendo feita como anteriormente, ou seja, o carteiro entrega as correspondências de alguns locais em postos comerciais próximos, para a entrega posterior pelo proprietário do estabelecimento. Exemplo disso são algumas pessoas cuja moradia está situada no entorno da via de pedestre José Leandro de Soares e da Constantino Lidarte, que têm suas correspondências entregues no Bar do KK, situado na esquina dessas vias. 
Anexo 16

Localização da Bacia do Guarapiranga 


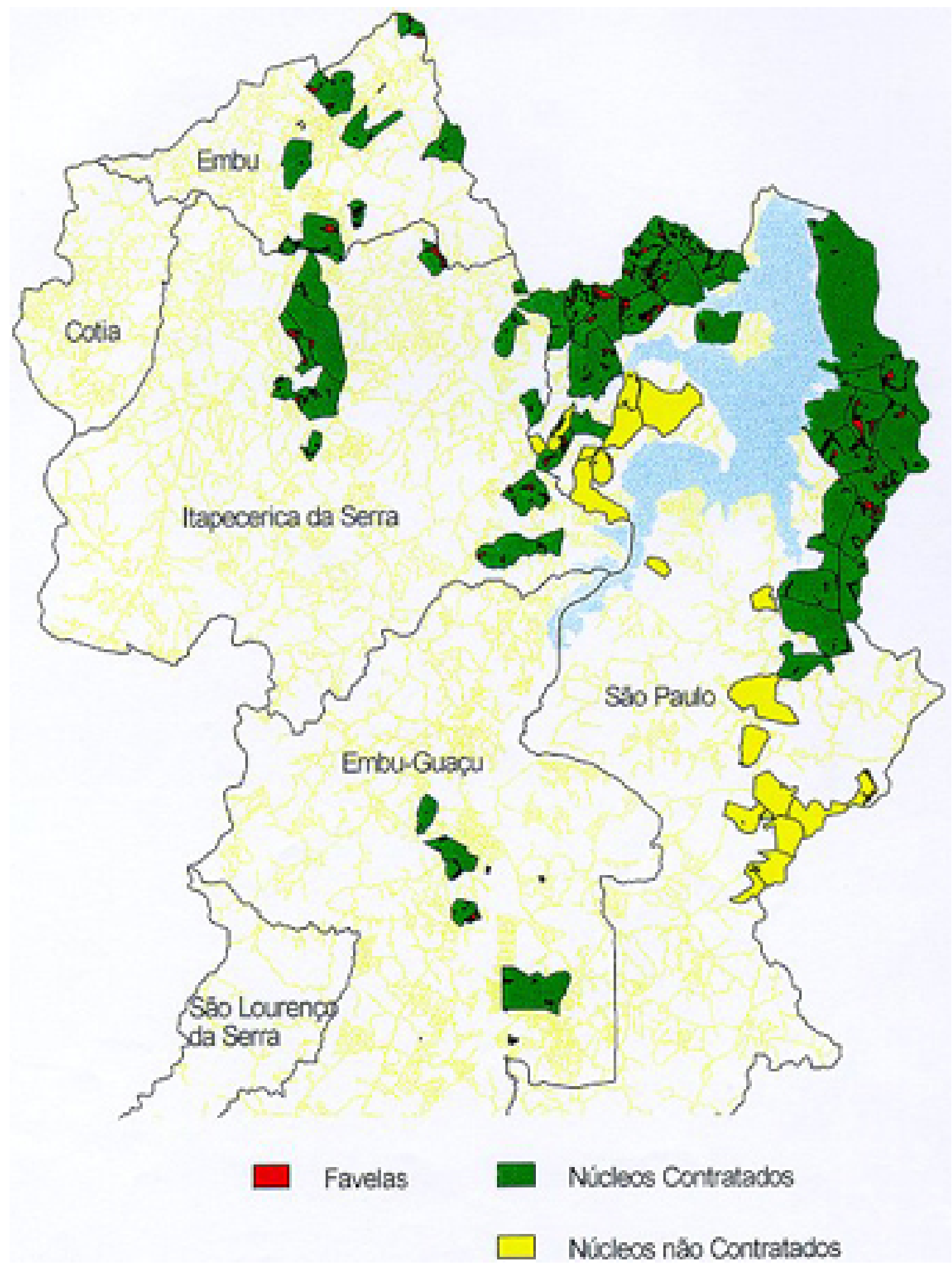

Figura 6.8: Localização da Bacia do Guarapiranga 